\title{
EVOLUÇÃO DE UM PROGRAMA UNIVERSIDADE-EMPRESA DE PESQUISA FLORESTAL COOPERATIVA
}

\author{
MAURICIO BUENO PENTEADO
}

Dissertação apresentada à Escola Superior de Agricultura "Luiz de Queiroz", Universidade de São Paulo, para obtenção do título de Mestre em Recursos Florestais, Área de Concentração: Economia Florestal.

PIR A C I C A B A

Estado de São Paulo - Brasil

Julho 2004 


\title{
EVOLUÇÃO DE UM PROGRAMA UNIVERSIDADE-EMPRESA DE PESQUISA FLORESTAL COOPERATIVA
}

\author{
MAURICIO BUENO PENTEADO \\ Engenheiro Florestal
}

Orientador: Prof. Dr. LUIZ CARLOS E. RODRIGUEZ

Dissertação apresentada à Escola Superior de Agricultura "Luiz de Queiroz", Universidade de São Paulo, para obtenção do título de Mestre em Recursos Florestais, Área de Concentração: Economia Florestal.

P I R A C I C A B A

Estado de São Paulo - Brasil

Julho 2004 


\section{Dados Internacionais de Catalogação na Publicação (CIP) DIVISÃO DE BIBLIOTECA E DOCUMENTAÇÃO - ESALQ/USP}

\section{Penteado, Mauricio Bueno}

Evolução de um programa universidade-empresa de pesquisa florestal cooperativa /

Mauricio Bueno Penteado. - - Piracicaba, 2004.

$109 \mathrm{p}$.

Dissertação (mestrado) - - Escola Superior de Agricultura Luiz de Queiroz, 2004.

Bibliografia.

1. Cooperativa florestal 2. Pesquisa florestal 3. Relação empresa-universidade I I. Título

CDD 634.9072 


\section{DEDICATÓRIA}

À minha esposa e filhos, pela paciência e compreensão, quando escolhi dar mais atenção a esta dissertação do que à família, a coisa mais importante que existe. 


\section{AGRADECIMENTOS}

A International Paper do Brasil, nas pessoas do Srs. João Comério e Julio Olhson, por apoiarem o desenvolvimento deste trabalho e pelo acesso às informações.

À Escola Superior de Agricultura Luiz de Queiroz, Universidade de São Paulo.

A todos os colegas da International Paper do Brasil, Fabiano Rodrigues, Rogério Silva, José Ferreira, Osmar Menegol, Dária Pimenta, Humberto Fantuzzi e Oswaldo Depieri, pela disposição para ajudar e pelo apoio crítico; principalmente a Kelly Oliveira, pela enorme ajuda.

Ao Sr. Manoel de Freitas, pelo carinho e orientação.

Aos meio amigos, pela compreensão e apoio nos momentos críticos.

Ao professor Luiz Carlos E. Rodrigues, pela orientação e suporte.

Aos professores Walter de Paula Lima, José Otávio Brito, Ricardo Shirota, Mário Ferreira e Luiz Ernesto Barrichelo, pela enorme contribuição crítica e sugestões.

A minha família pelo apoio incondicional. 


\section{SUMÁRIO}

Página

LISTA DE TABELAS …......................................................... vii

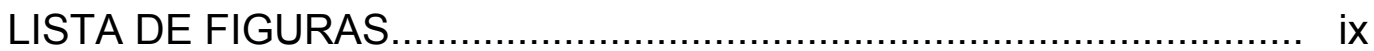

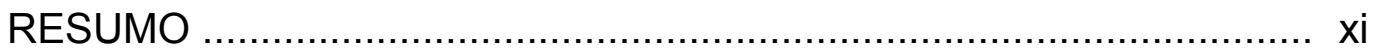

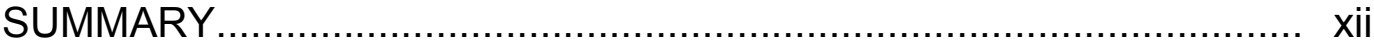

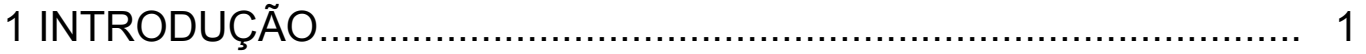

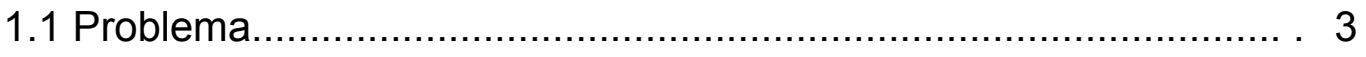

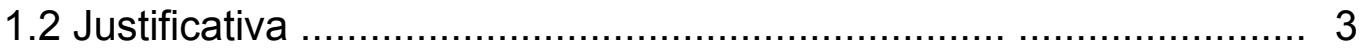

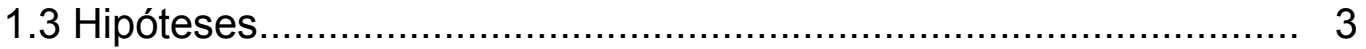

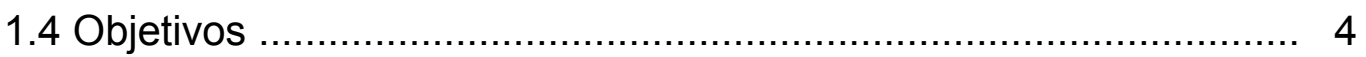

2 REVISÃO DE LITERATURA ….................................................. 5

2.1 Evolução da pesquisa florestal no Brasil ..................................... 5

2.2. A integração Universidade x Empresa......................................... 12

2.3 Instituto de Pesquisas Florestais - IPEF ....................................... 13

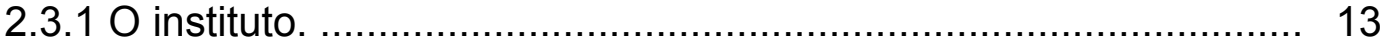

2.3.2 A contribuição do IPEF para o desenvolvimento florestal

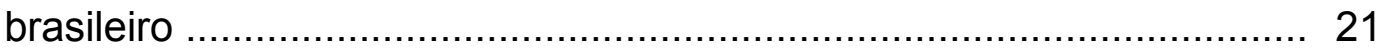

2.4 Evolução das pesquisas na International Paper do Brasil .............. 28

2.4.1 Melhoramento genético .................................................... 29

2.4.2 Manejo florestal ............................................................. 36

2.4.3 Tecnologia da madeira .................................................. 38

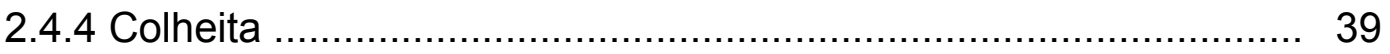




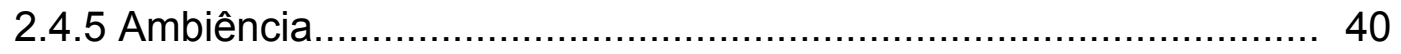

2.5 A Análise econômica do retorno em pesquisa............................... 40

3 MATERIAL E MÉTODOS ......................................................... 47

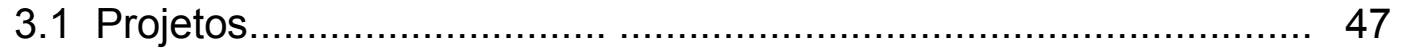

3.1.1 Levantamento dos projetos.............................................. 47

3.1.2 Classificação dos projetos....................................................... 48

3.2 Produtividade e qualidade ...................................................... 50

3.2.1 Levantamento das produtividades.......................................... 50

3.2.2 Outros levantamentos....................................................... 52

3.3 Levantamento dos valores investidos...................................... 54

3.4 Cálculo do retorno financeiro sobre o investimento em pesquisa..... 55

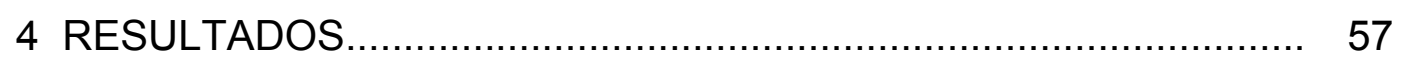

4.1 Benefícios da pesquisa para a produtividade e qualidade............... 57

4.2 Projetos apoiados pela integração UniversidadexEmpresa.............. 67

4.3 Valor do investimento em pesquisa............................................. 74

4.4 Análise dos benefícios financeiros.............................................. 83

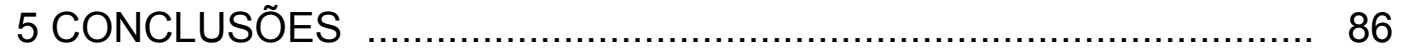

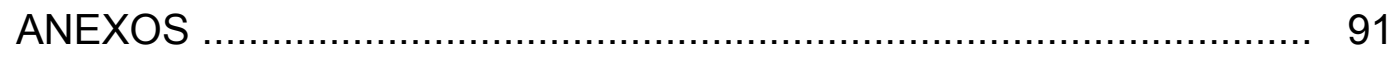

REFERÊNCIAS BIBLIOGRÁFICAS................................................. 102 


\section{LISTA DE TABELAS}

Página

1 Desenvolvimento das pesquisa florestais no Brasil

2 Evolução dos programas cooperativos e programas temáticos do IPEF

3 Base genética dos primeiros clones recomendados na empresa

4 Evolução da clonagem na International Paper do Brasil......... 32

5 Evolução do processo de produção de mudas na International Paper do Brasil

6 Evolução da Cultura de Tecidos na International Paper do Brasil.

7 Evolução da colheita florestal na International Paper do Brasil 39

8 Evolução dos rendimentos em produtividade de colheita florestal na International Paper do Brasil.................................. 39

9 Proposta de classificação de projetos por grupos e subgrupos

10 Classes de agrupamento de dados por período de 5 anos.

11 Levantamento dos valores investidos em pesquisa no IPEF entre os anos de 1996 a 2003.

12 Levantamento dos valores investidos médios (US\$) de 1996 a 2003 por período 
13 Composição dos valores investidos no IPEF (US\$) de 1999 a 2003 .......................................................................... 75

14 Valores bases para estimativa dos investimentos realizados.. 79

15 Levantamento das estimativas dos valores de investimento.... 81

16 Dados para elaboração do fluxo de caixa............................... 84

17 Fluxo de caixa para retorno em pesquisa na IPB.................... 84

18 Resultados da análise econômica para fluxo de caixa.............. 85

19 Levantamento de projetos do IPEF..................................... 100 


\section{LISTA DE FIGURAS}

Página

1 Composição dos projetos do IPEF em 1971 ............................. 15

2 Evolução do numero de empresas associadas ao IPEF.............. 19

3 Estrutura operacional do IPEF …....................................... 20

4 Esquema geral da estratégia clonal da International Paper do Brasil: (A) em 1996 e (B) em 2004 ......................................... 33

5 Curva de excedente de produção e consumo ............................. 43

6 Curva da função de produção ................................................. 44

7 Evolução da sobrevivência para as florestas plantadas............... 58

8 Evolução da produtividade para as florestas plantadas.............. 59

9 Evolução dos aumentos do incremento médio anual das

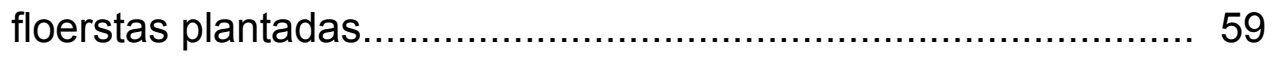

10 Evolução do rendimento em celulose na madeira......................... 60

11 Variação do consumo específico na fábrica............................... 61

12 Evolução do plantio clonal por ano $\mathrm{x}$ número de clones por ano na IPB

13 Evolução da participação de madeira de origem clonal na

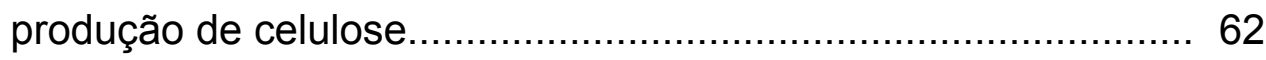

14 Evolução dos custos de madeira em pé US $\$ / \mathrm{m}^{3} \ldots \ldots \ldots \ldots \ldots \ldots \ldots \ldots . . . . . . . . .63$

15 Evolução da produção de celulose admt / ano para a fábrica da International Paper em Mogi Guaçu........................................ 64 
16 Variação da área necessária para abastecimento da fábrica em função da melhoria da qualidade de madeira............................ 65

17 Estimativa de autosuficiência em função da produtividade e da produção de celulose ......................................................... 66

18 Levantamento dos projetos do IPEF, em parceria com a IPB em função do grupos e classes de ano......................................... 67

19 Participação percentual dos grupos dos projetos do IPEF em

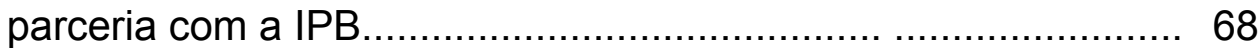

20 Temas do sub-grupo adubação ............................................. 69

21 Temas do sub-grupo melhoramento ……............................... 70

22 Aplicabilidade dos projetos por período ……........................... 71

23 Aplicabilidade total dos projetos ………….......................... 71

24 Aplicabilidade dos projetos por área …………..................... 72

25 Aplicabilidade dos projetos por sub-área ……........................ 73

26. Composição percentual dos valores investidos se 2000 a 2003.. 76

27 Composição dos valores investidos (US\$) de 1999 a 2003........ 77

28 Valor médio por projeto. ................................................ 78

29 Valores estimados para investimentos em projetos pela IPB..... 80

30 Valores totais investidos pela International Paper em pesquisa

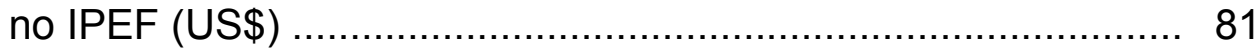

31 Valores totais investidos pela International Paper em pesquisa

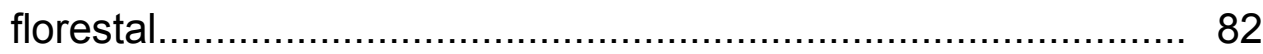

32 Percentual Investido no IPEF em relação ao total investido em pesquisa florestal........................................................... 82

33 Custo percentual da pesquisa na produção de celulose.............. 83 


\title{
EVOLUÇÃO DE UM PROGRAMA UNIVERSIDADE-EMPRESA DE PESQUISA FLORESTAL COOPERATIVA
}

\author{
Autor: MAURICIO BUENO PENTEADO \\ Orientador: Prof. Dr. LUIZ CARLOS E.RODRIGUEZ
}

\section{RESUMO}

Este trabalho analisa a evolução da pesquisa florestal conduzida pelo Instituto de Pesquisas Florestais - IPEF em parceria com a International Paper do Brasil. O IPEF foi criado em 1968, com a missão de promoção do desenvolvimento científico, tecnológico e sustentável do setor florestal, servindo de elo de ligação entre a universidade e a empresa. O trabalho discute os benefícios gerados por essa parceria em um estudo de caso, por meio da caracterização dos valores investidos e da análise dos resultados obtidos, tendo como base os projetos desenvolvidos em entre o IPEF e a IPB, no período de 1968 a 2004. A análise revela ganhos para a universidade, na captação de recursos na iniciativa privada, viabilizando projetos propostos no âmbito da ciência e tecnologia e para as empresas, utilizando os resultados gerados pelas pesquisas. Há evidências que justificam a manutenção de um modelo de pesquisa florestal cooperativo universidade-empresa como o preconizado pelo IPEF em convênio com a Universidade de São Paulo. 


\title{
EVOLUTION OF A UNIVERSITY-COMPANY COOPERATIVE FORESTRY PROGRAM
}

\author{
Author: MAURICIO BUENO PENTEADO \\ Adviser: Prof. Dr. LUIZ CARLOS E.RODRIGUEZ
}

\section{SUMMARY}

This work analyzes the evolution of the forest research lead by the Instituto de Pesquisas Florestais - IPEF in partnership with International Paper do Brasil. The IPEF was created in 1968 with the mission of promotion of the scientific, technological and sustainable development of the forest sector, serving as a link between the university and the company. The work discusses the benefits generated by this partnership in a case study, through the characterization of the invested values and the analysis of the obtained results, having as base the projects developed between IPEF and IPB in the period of 1968 to 2004. The analysis discloses profits for the university, through the obtainment of resources from the private initiative, enabling projects considered in the scope of science and technology and for the companies, using the results generated by research. There are evidences that justify the maintenance of a model of a universitycompany forest research cooperative as professed by IPEF in accord with the University of São Paulo. 


\section{INTRODUÇÃO}

O setor florestal brasileiro figura com destaque no cenário econômico nacional e tem, nos últimos anos, apresentado números significativos para a balança comercial brasileira.

A SBS(www.sbs.com.br), em 2001, afirma que o setor responde por:

- 5,4 bilhões de dólares em exportações (2002), aproximadamente $8 \%$ do total das exportações;

- cerca de $4 \%$ na formação do PIB Nacional;

- cerca de $3 \%$ de todo comércio mundial do setor;

- $28 \%$ do superávit da balança comercial brasileira (2002);

- 1,6 milhão de empregos diretos e 5,6 milhões de empregos indiretos;

- R\$ 3 bilhões de impostos em arrecadação; e

- 6,4 milhões de hectares de florestas plantadas, sendo 4,8 milhões com florestas de produção de Eucalyptus e Pinus.

No perfil do desenvolvimento florestal brasileiro ao longo dos anos, podem-se notar quatro principais eventos que contribuíram para a atual configuração do setor florestal brasileiro.

Primeiramente, deve-se destacar o trabalho do Dr. Navarro de Andrade, no início do século $X X$, responsável pela introdução de inúmeras espécies de Eucalyptus no estado de São Paulo. Por meio desse esforço, foram viabilizados os reflorestamentos com Eucalyptus para atender à demanda de madeira da época, principalmente para dormentes, postes e energia (Galvão, 1982). Atualmente, o Eucalyptus continua a ser plantado em grande escala, com as 
finalidades mais variadas, ainda que especialmente voltado para os mercados de celulose e papel, carvão, madeira serrada e chapa de fibras.

O segundo evento foi a lei de incentivos fiscais para o reflorestamento, a partir da década de 1960, criando as condições necessárias para a produção racional de madeira para energia e processamento mecânico, além de permitir a substituição de produtos importados como a celulose (Soresini, 1993). Essa condição possibilitou a incorporação de terras ao processo produtivo, até então marginais, aumentando o potencial produtivo nacional.

$\mathrm{O}$ terceiro evento que impulsionou o desenvolvimento das pesquisas florestais foi a criação das primeiras escolas de formação em Engenharia Florestal, a partir de 1960 (UFV, UFPR e ESALQ/USP) e a posterior criação dos institutos de pesquisa (IPEF, FUPEF e SIF), que promoveram a difusão de novos conhecimentos, possibilitando o aumento da produtividade e qualidade das florestas plantadas. Foram também criados institutos de pesquisa no âmbito federal (EMBRAPA) e estadual (Instituto Florestal), contribuindo para o avanço da pesquisa florestal brasileira.

$\mathrm{O}$ quarto ponto a se destacar foi o investimento em pesquisas, feito principalmente pelas grandes empresas de papel e celulose a partir dos anos 1970, apoiando financeiramente as instituições de pesquisa e universidades, por meio de convênios e associações e investindo na contratação de profissionais qualificados, laboratórios de pesquisa e equipamentos de análise.

Esses fatores, aliados a outros, como disponibilidade de terras, clima favorável, e mão-de-obra barata, fizeram com que a indústria florestal tivesse a importância mencionada, caracterizando-se pelo desenvolvimento por meio de tecnologias geradas no país e tendo reconhecimento mundial no domínio de tecnologia ligadas ao setor produtivo florestal. 


\subsection{Problema}

A difícil quantificação dos retornos líquidos obtidos com os investimentos realizados em pesquisa florestal faz com que muitas empresas tenham dificuldade para justificar a manutenção dos atuais níveis de investimento nos seus centros de pesquisa e em programa complementares. O modelo de integração universidade-empresa para pesquisa tem sido usado como estratégia complementar e, entretanto, poucos têm sido também os trabalhos de avaliação desses programas. Este trabalho procura amenizar essa carência.

\subsection{Justificativa}

A ausência de avaliações que justificam a integração de recursos, privados ou públicos, para o desenvolvimento da ciência e da tecnologia pode dificultar a continuidade de programas cooperativos atualmente existentes. Este trabalho procura avaliar os benefícios da cooperação que envolve a integração dos recursos científicos florestais disponíveis na universidade pública e na empresa privada, e se justifica pela contribuição que pode trazer para o futuro desenvolvimento de um modelo geral de avaliação dos retornos da pesquisa e da alocação de recursos por parte das empresas em programas cooperativos.

\subsection{Hipóteses}

Para nortear a avaliação proposta neste trabalho, foram formuladas quatro hipóteses, que são apresentadas a seguir:

a) o aumento da produtividade e da qualidade das florestas plantadas na IP é decorrente do investimento que foi realizado ao longo do tempo em pesquisa florestal;

b) o esforço de pesquisa da IP destinado ao modelo universidade-empresa organizou-se em torno de áreas específicas do conhecimento florestal ao longo do tempo; 
c) nos últimos anos, o modelo universidade-empresa vem sendo mais utilizado para desenvolver pesquisas que exigem um nível maior de investimento;

d) o retorno dos recursos investidos no modelo universidade-empresa para pesquisa florestal é maior que a taxa esperada de retorno dos investimentos da empresa.

\subsection{Objetivos}

Para corroborar as hipóteses formuladas, foram propostos os seguintes objetivos:

a) evidenciar o aumento da produtividade e da qualidade florestal;

b) identificar os temas de pesquisa florestal coordenados pelo IPEF, fazendo uma análise de sua evolução ao longo do tempo;

c) propor indicadores de avaliação quantitativos e qualitativos do desempenho das pesquisas;

d) interpretar e discutir os indicadores propostos;

e) calcular o retorno direto dos investimentos em pesquisa;

f) interpretar e discutir os retornos encontrados. 


\section{REVISÃO DE LITERATURA}

\subsection{Evolução da pesquisa florestal no Brasil}

Segundo Rodriguez et al. (2002), a pesquisa florestal brasileira tem seu marco inicial em 1860, com a criação da Secretaria da Agricultura, Comércio e Obras Públicas.

As primeiras plantações experimentais, baseadas em critérios técnicocientíficos, com espécies do gênero Eucalyptus, iniciaram-se em 1904. Os trabalhos de Navarro de Andrade serviram para introduzir a eucaliptocultura no Brasil, objetivando ampliar a oferta de madeira, atendendo às necessidades crescentes das estradas de ferro, produzir energia e matéria-prima para a fabricação dos dormentes. A criação do Serviço Florestal em 1921 estruturou, e passou a gerir de forma regular, a pesquisa voltada para o manejo e a produção de bens e serviços florestais.

A característica extrativista prevaleceu até a década de 1950, tendo como exemplo a extração de araucária (Araucaria angustifolia). A partir de 1960, a pesquisa florestal com espécies exóticas foi consolidada e expandida, culminando com a realização da $2^{\mathrm{a}}$ Conferência Mundial do Eucalipto, que viria a ter enorme repercussão nacional (Poggiani et al. ${ }^{1}$ ).

\footnotetext{
${ }^{1}$ POGGIANI, F.; FERREIRA, M.; LIMA, W.P. A silvicultura no Brasil: Contribuição do Departamento de Ciências Florestais. ESALQ: Piracicaba, 1996. 15p. (não publicado)
} 
Em 1960 surgiu também, na cidade de Viçosa, MG, a primeira instituição de ensino especializado, por meio de um convênio entre a Ministério da Agricultura, o Ministério da Educação e a Universidade Rural de Minas Gerais, sendo dois anos depois transferida para a Universidade Federal do Paraná, em Curitiba. Mais tarde, surgiram outros cursos de Engenharia Florestal, na Universidade Federal do Rio de Janeiro (UFRJ), em 1967 e na Escola Superior de Agricultura "Luiz de Queiroz" (ESALQ), em 1968.

Segundo Soresini (1993), os projetos florestais implantados na década de 1960 tinham, muitas vezes, a característica de pioneirismo. É o caso dos plantios da Jari Celulose, no Pará, que, de acordo com o manejo silvicultural da época, foram implantados com mudas de materiais não adaptados à região, pois não existiam pesquisas e nem sementes geneticamente melhoradas. Como resultado, os plantios obtidos possuíam características genéticas e fenotípicas não desejadas, além da baixa produtividade.

A silvicultura intensiva brasileira se caracterizava, na década de 1960, por:

a) utilização exclusiva das sementes produzidas e distribuídas pela Cia. Paulista de Estradas de Ferro;

b) produção de mudas baseadas nas embalagens "torrão paulista", "torronetes" e laminados (sul do Brasil);

c) adoção de sistemas de plantio que utilizavam o fogo, com preparo do solo pouco intenso e uso limitado da adubação; os espaçamentos de plantio eram fechados $(2 \times 2 \mathrm{~m})$, tendo-se 2.500 plantas/ha visando "garantir a maior sobrevivência nos três ciclos de corte", previstos para as curtas rotações e, finalmente, por rendimentos médios variando de 17 a $20 \mathrm{~m}^{3} /$ ha de madeira com casca. A condução da brotação após o corte era baseada nos trabalhos desenvolvidos pela Cia. Paulista de Estradas de Ferro (Andrade citado por Poggiani et al., 1996).

Data ainda dessa década, o Zoneamento Bioclimático do Sul do Brasil para o plantio de coníferas, primeiro trabalho desenvolvido para definir os 
parâmetro básicos de manejo, já com a perspectiva de produção de massa (Hosokawa, 1999).

Os primeiros trabalhos de adubação mineral em viveiros foram realizados por volta de 1965, em decorrência da produção de mudas em escala comercial, e dificuldades na obtenção de grandes quantidades daquele material visando à eliminação do uso dos componentes do substrato utilizado para a produção de mudas. Os trabalhos iniciais foram muito empíricos, sem bases científicas, restringindo-se à aplicação de doses de NPK (nitrogênio, fósforo e potássio) e da observação do nascimento das mudas sem estabelecerem-se critérios para a interpretação e previsão de resultados. No final da década de 1970, aprimoraram-se as pesquisas científicas, com a preocupação de conhecer as causas e respostas da planta aos diferentes níveis e tipos de adubação. Apenas a partir dos anos 1980 estudos voltados à adubação de campo foram intensificados.

Dada a inexistência de material genético básico apropriado, no início da década de 1970, iniciaram-se os programas de introdução de espécies e procedências, especialmente dos gêneros Eucalyptus e Pinus, visando à definição do material genético que se adapta melhor às diferentes condições edafoclimáticas de interesse econômico e social para o reflorestamento no Brasil.

O início das pesquisas florestais no Brasil foi marcado pela ausência de preocupações ambientais e ecológicas, que passaram a se intensificar somente a partir de 1970, principalmente aquelas relacionadas com a avaliação de possíveis impactos ambientais no solo e na água (Rodriguez et al., 2002).

Ainda segundo Rodriguez et al. (2002) e Poggiani et al. (1996), a escassez de petróleo e o receio de que a falta do produto pudesse afetar o crescimento do país fizeram com que, a partir de 1973, aumentasse o interesse por outras fontes de energia, em especial a oriunda da biomassa florestal e da produção de carvão. Os estudos envolveram também a avaliação de madeiras (nativas e de florestas plantadas) quanto à sua potencialidade para a produção 
de energia, desenvolvimentos de processos de produção de carvão em diferentes escalas e utilização de subprodutos do carvoejamento. Ainda naquela década, ocorreram algumas contribuições voltadas para a área de celulose e papel, principalmente na qualidade da madeira e na definição de parâmetros, tais com densidade para utilização no melhoramento florestal.

As pesquisas para a projeção ou predição de volume, até a metade da década de 1970, voltaram-se basicamente para a construção de tabelas de volume. Os estudos baseavam-se ou preocupavam-se com a árvore individual e não com o povoamento como um todo. As primeiras tabelas de volume foram construídas para essências florestais nativas, mas, à semelhança do que ocorreu com a ciência florestal como um todo, posteriormente foi dada mais ênfase às essências exóticas (Rezende, 1993).

No final dos anos 1970, foram estabelecidos os primeiros pomares clonais para a produção de sementes. Já no que tange aos plantios clonais comerciais, Alfenas \& Zauza (2002) relatam que os mesmos tiveram início na mesma década, tendo como principais objetivos a redução da heterogeneidade entre os plantios e a multiplicação massal de indivíduos resistentes ao cancro, sendo possível então, perpetuar e propagar as melhores combinações genotípicas (Andrade, 2002).

Concomitantemente ao desenvolvimento e divulgação das vantagens da utilização de clones, foram desenvolvidas técnicas de propagação vegetativa que tornaram viável a obtenção de milhões de indivíduos de uma mesma planta e, assim, atender à demanda de plantio para todas as empresas florestais (Campinhos \& Ikemori, 1983; Xavier \& Comério, 1996; Wendling et al., 2000).

As pesquisas sobre os tratamentos silviculturais realizados nas florestas tiveram grande impulso com os trabalhos de Fishwick (1974). Suas pesquisas sobre intensidade de desbaste foram as primeiras tentativas de se obter informações necessárias que permitissem o desenvolvimento de processos sistemáticos em tratamentos de povoamentos florestais do ponto de vista de produção volumétrica. 
Já na questão de viveiros, foram obtidos avanços significativos, principalmente em relação à propagação vegetativa por enraizamento de estacas. Na década de 1980, com a introdução dos tubetes e a mudança de substratos, iniciou-se uma nova fase de testes de adubação de mudas, em função da variação dos diferentes materiais (casca de Eucalyptus, vermiculita, casca de arroz e de Pinus carbonizada, etc.). Pesquisas foram realizadas não só a respeito da quantidade de nutrientes, como também na melhor taxa de liberação dos mesmos.

Segundo Rezende (1993), no final da década de 1970, a introdução de conceitos de modelagem matemática trouxe avanços para a pesquisa em manejo, voltada para a predição de crescimento e produção. Os primeiros artigos científicos e teses, usando técnicas de modelagem matemática, começaram a circular no meio científico florestal a partir da década de 1980, permitindo um avanço significativo, no sentido de permitir a verificação dos efeitos de tratamentos silviculturais como fertilização, espaçamento, desbastes, preparo do solo, dentre outros, sobre o desenvolvimento e estrutura dos povoamentos. A partir da década de 1990, ainda, por meio da modelagem matemática, as pesquisas da área associaram-se a outros fatores, tais como a aspectos econômicos e a prognose de multiprodutos.

A partir de 1976, com a redução dos incentivos fiscais para o setor florestal e o aumento da competição, as preocupações com os custos passaram a ser maiores. As empresas tiveram que produzir mais e melhor, com custos menores. A pesquisa florestal foi revista, passando, muitas empresas e instituições de pesquisa florestal, a reduzirem seus investimentos. $O$ novo ambiente para pesquisa é caracterizado pela busca da árvore superior. As pesquisas de competição entre espécies/procedências, pomares de produção de sementes, polinização controlada, hibridação e testes de progênie são reduzidas ou canceladas, tendo como foco as pesquisas em propagação vegetativa (Poggiani et al.,1996). 
Nos anos 1980, são categorizadas quatro grandes áreas temáticas para pesquisa: a ambiência, o manejo florestal, a silvicultura e a tecnologia de produtos florestais.

No final dos anos 1980, a mecanização florestal também foi destaque, tendo como principal objetivo a redução da mão-de-obra empregada e o aumento da produtividade (Freitas et al.,1993).

No início da década de 1990, iniciou-se a preocupação com os aspectos microambientais (Rezende, 1993).

Nessa mesma época, iniciaram-se os estudos sobre microestaquia, utilizando plantas rejuvenescidas "in vitro" como fonte de propágulos vegetativos, sendo esta uma importante ferramenta para a clonagem nas empresas, principalmente as de papel e celulose, que concentram esforços na seleção e recomendação de um número reduzido de clones. Os testes clonais, além das características silviculturais dos clones, incluem estudos de qualidade da madeira (Assis et al.,1996) e (Xavier et al., 1997).

Adicionalmente, também na década de 1990, observou-se a implementação de técnicas de cultivo mínimo, as quais implicam em redução substancial das perdas de solo por processos de erosão laminar. Essa técnica foi otimizada de forma a permitir a aplicação de um mínimo de insumos e a utilização menos intensiva da mecanização nos processos de plantio e reforma das áreas florestadas (Freitas \& Siqueira Júnior, 1993).

$\mathrm{Na}$ área de mecanização, atualmente, as pesquisas estão voltadas para o controle da compactação do solo pela exploração florestal, controle do impacto da construção de estradas, controle de impactos ambientais, estudos de sistemas altamente mecanizados, desenvolvimento de sistema de planejamento e controle de manutenção mecânica, planejamento e controle da exploração florestal, estabilização de solos de superfície de estradas com resíduos sólidos da indústria de celulose, desenvolvimento de máquinas e equipamentos para exploração florestal (Sousa et al., 1999). 
A Tabela 1 mostra a preocupação com os temas de pesquisa florestal e seu desenvolvimento ao longo dos anos.

Tabela 1. Desenvolvimento das pesquisas florestais no Brasil

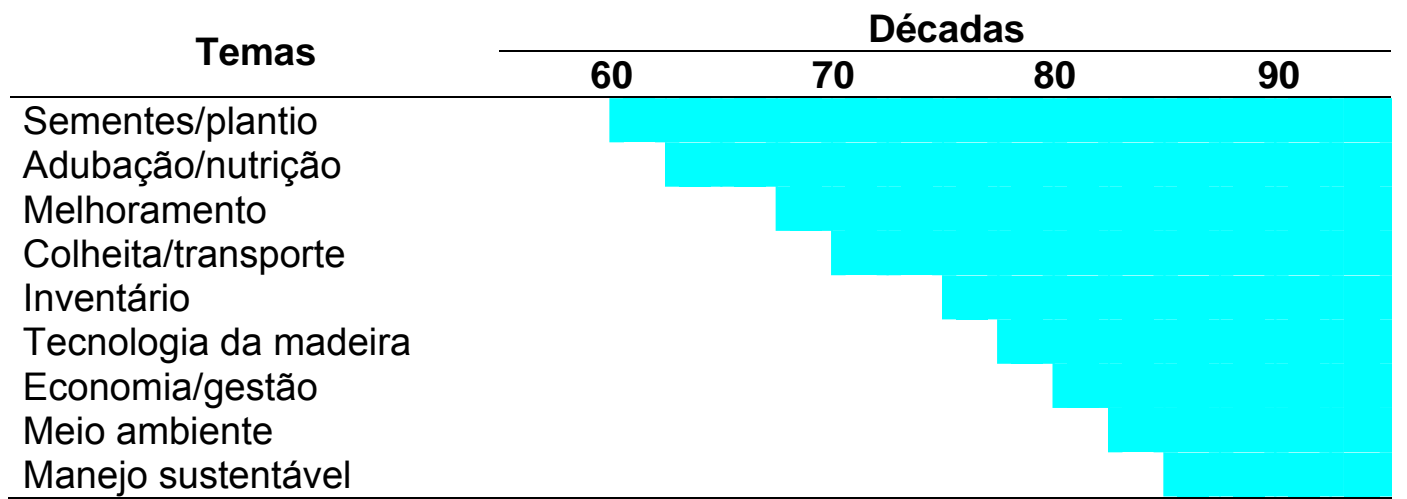

Fonte : (Ladeira, 2002)

Segundo Rodriguez et al. (2002), podem-se definir linhas prioritárias em pesquisa florestal atualmente no Brasil nas áreas de:

a) conservação dos recursos hídricos, por meio do estudo de microbacias e o ordenamento de espaços produtivos;

b) uso de sistemas integrados de produção;

c) criação de indicadores de sustentabilidade florestal, em face das necessidades da obtenção de registros e certificações;

d) desenvolvimento de novas técnicas e equipamentos, visando o aumento da produtividade e à redução dos impactos ambientais;

e) desenvolvimento de técnicas de construção e manutenção de estradas, visando minimizar impactos hidrológicos;

f) desenvolvimento de modelos ecofisiológicos de produção florestal e;

g) desenvolvimento de tecnologias de biotecnologia.

\subsection{A integração universidade $x$ empresa}


Segundo Segatto-Mendes (2001), a integração empresa-universidade representa um instrumento de pesquisa entre instituições empresariais públicas e privadas com instituições de pesquisa e universidades, com o objetivo de desenvolvimento de conhecimento.

O desenvolvimento de projetos de pesquisa em cooperação com universidades tem garantido a muitas organizações o acesso a inovações tecnológicas, assegurando a competitividade a um custo inferior ao do desenvolvimento privado da pesquisa, devido às condições de acesso ao conhecimento e à infra-estrutura de laboratórios que, em geral, os pesquisadores encontram em universidades e institutos de pesquisa financiados com recursos públicos. Assim, a cooperação é uma forma de reunir potencialidades e oportunidades, reduzindo as dificuldades para alcançar o desenvolvimento tecnológico tão necessário às empresas (Porto, 2000).

A pesquisa e o desenvolvimento (P\&D) podem envolver não apenas 0 aumento do conhecimento científico (pesquisa) ou o ajustamento e experimentação de novos conhecimentos (desenvolvimento), mas também atividades relacionadas ao apoio técnico e/ou serviços tecnológicos. Além disso, as pesquisas básicas, representando a busca por um entendimento fundamental do fenômeno natural (Rosenberg \& Nelson, 1994), não implicam numa total ausência de aplicabilidade prática.

Desse modo, como a investigação científica estimulada pelo setor produtivo inclui questões de pesquisa básica voltadas para o desenvolvimento de meios que expressem a sua aplicação, a integração universidade-empresa também pode resultar na realização de pesquisa básica e aplicada.

Outros pontos importantes em programas cooperativos devem ser mencionados:

a) servem como um foro de discussões de problemas, além da integração entre técnicos das universidades e empresas e professores;

b) permitem, por meio de experimentos, a modelagem de fenômenos e a solução eficaz de problemas e; 
c) são ferramentas de extensão para a transferência de tecnologia gerada nas universidades, institutos de pesquisa e empresas para a sociedade.

\subsection{Instituto de Pesquisas Florestais - IPEF}

\subsubsection{O Instituto}

O Instituto de Pesquisas Florestais, IPEF, criado em 1968, é uma sociedade civil sem fins lucrativos, cuja missão é a promoção do desenvolvimento científico, tecnológico e sustentável do setor florestal (IPEF, 2002).

Ainda segundo IPEF (2002), para cumprir sua missão, o instituto tem como objetivos:

a) promover a integração e a interação do meio científico e empresarial, a realização de pesquisas e a capacitação de recursos humanos;

b) manter estreito contato e colaboração com organizações congêneres nacionais e estrangeiras;

c) apoiar a manutenção de centros de pesquisa, laboratórios, bibliotecas especializadas e outras estruturas afins;

d) promover e ou apoiar a realização de simpósios, seminários, "workshops", cursos e atividades afins;

e) divulgar e ou apoiar trabalhos de natureza técnico-científica mediante publicações (livros, revistas, jornais, etc.) e mídia eletrônica (internet, cd-rom, etc.) e;

f) produzir e disponibilizar sementes florestais com qualidade genética, física e fisiológica comprovada para as empresas florestais, produtores rurais, entidades de pesquisa e sociedade em geral.

Segundo Leão (2000), o IPEF surgiu, pelas mãos do Srs. Helládio do Amaral Mello e Ronaldo Algodoal Guedes Pereira, da necessidade de interação entre a iniciativa privada e a universidade, baseando-se no tripé 
ensino/pesquisa/extensão. A concretização definitiva da idéia de se criar um instituto surgiu em 1967, na antiga Champion Papel e Celulose, em uma reunião com representantes 13 das principais indústrias em atividade no setor florestal, além do presidente do antigo Instituto Brasileiro de Desenvolvimento Florestal (IBDF), atual Instituto Brasileiro do Meio Ambiente e Recursos Naturais (Ibama), o general Silvio Pinto da Luz.

Essa reunião produziu um documento de seis páginas, relatando que a crescente demanda por matéria-prima de origem florestal exigia um planejamento de longo prazo de políticas públicas, trazendo a proposta de criação do Fundo de Pesquisas Florestais (FuPeF). De acordo com o documento, os trabalhos de pesquisa aprovados e financiados pelo FupeF teriam seus resultados publicados e pertenceriam a todos os participantes, sendo a idéia original da criação de um fundo posteriormente transformada em um instituto. Em 20 de dezembro de 1967, realizou-se outra reunião, agora com 18 empresas do setor, onde foi discutida a constituição do IPEF, já então com seu nome definitivo e estatutos sociais estabelecidos.

Sua estruturação como instituição sem fins lucrativos só foi possível graças a um convênio firmado com a Universidade de São Paulo (USP), por meio do Departamento de Silvicultura (hoje Ciências Florestais) da Escola Superior de Agricultura Luiz de Queiroz (ESALQ).

Baseando-se no modelo bem sucedido nos paises desenvolvidos, o instituto alicerçou-se, desde a criação, em uma parceria, tendo de um lado o suporte financeiro e apoio operacional das empresas e, de outro, a universidade, realizando pesquisa de vanguarda e divulgando os conhecimentos adquiridos para o aperfeiçoamento das atividades do setor (Leão, 2000).

No início da década de 1970 foi contratada uma equipe própria para o IPEF, que era composta por três engenheiros e dez funcionários, sendo o corpo docente do Departamento de Ciências Florestais responsável pela elaboração dos projetos de pesquisa e orientação técnica para sua execução. A Figura 1 
mostra que, em 1971, o instituto contava com 13 empresas participantes e 115 projetos em andamento.

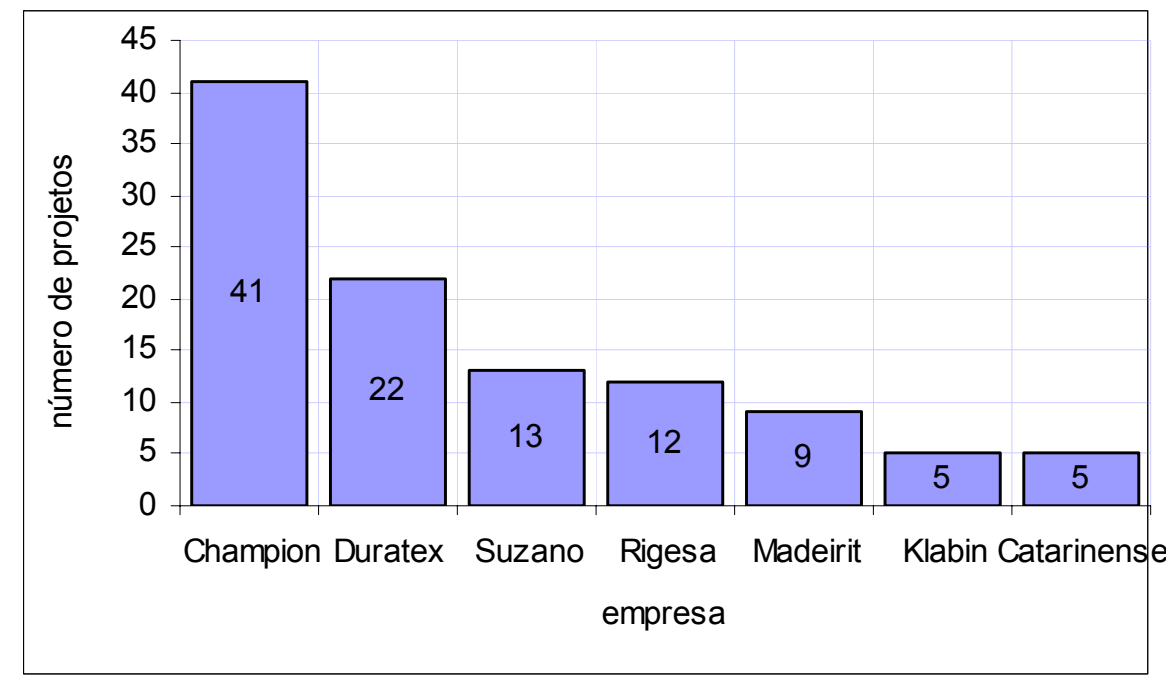

Figura 1 - Composição dos projetos do IPEF em 1971

Fonte: Barrichello (1993)

Nota-se que, na época (Figura 1), $36 \%$ dos projetos eram realizados na Champion Papel e Celulose, atual International Paper do Brasil.

A biblioteca Prof. Helládio do Amaral Mello foi fundada em fevereiro de 1973. Seu acervo bibliográfico, essencialmente florestal, serve para apoio à pesquisa, extensão e ensino realizado no curso de Engenharia Florestal da ESALQ/USP, em nível de graduação e pós-graduação.

A USP adquiriu simbolicamente, em maio de 1974, diretamente da Companhia Energética de São Paulo (CESP) uma área de 506,67 ha, situada no município de Anhembi, SP. A aquisição da área, segundo (1993), nada mais era do que um reconhecimento da CESP pelos trabalhos desenvolvidos pelo IPEF e pelo Departamento de Silvicultura na área florestal. A implantação da Estação Experimental de Anhembi nessa mesma área ocorreu em 1975, tendo como objetivo básico desenvolver pesquisas nas áreas de melhoramento 
genético, produção de sementes florestais, ecologia e manejo de áreas silvestres.

Para difundir a tecnologia gerada pela integração empresa- universidade, a partir de 1974, foram oficializadas reuniões conjuntas, reuniões técnicas regionais, cursos de atualização, seminários e simpósios e reuniões técnicas de interesse específico (Ferreira, 1993).

Segundo Leão (2000), o setor tinha suas linhas de atuação definidas como:

a) produção, critério e avaliação da qualidade, comercialização no mercado interno e externo, coleta, beneficiamento, tratamento e armazenamento de sementes;

b) pesquisa em biologia reprodutiva de espécies florestais, visando o setor de florestas nativas; dada a carência de informações, a ênfase foi dada para pesquisa básica em aspectos ligados a sementes em ecossistemas naturais. As linhas prioritárias eram:

- biologia floral (interação flor x polinizador: fluxo gênico);

- fenologia de crescimento e frutificação (efeito de clima: periodicidade);

- dispersão de sementes (padrões de dispersão, predação de sementes) e;

- dormência e armazenamento.

Em 1977, por meio do convênio efetuado entre a Ferrovia Paulista S/A (FEPASA) e a USP, o IPEF assumiu a responsabilidade sobre a Estação Experimental de Itatinga, área de 2.400 ha, pertencente ao Patrimônio do Estado de São Paulo, doada pelo governo do estado (Decreto Lei 1744 de 21 de agosto de 1978) para a USP. Nela são coletadas sementes de Eucalyptus que são comercializadas pelo IPEF. Nesse mesmo ano foi formada uma comissão especial para discutir e apresentar um relatório sobre a expansão do IPEF (Barrichello 1993). 
A partir de 1979, a estrutura organizacional do IPEF era composta por três diretorias, duas coordenadorias e onze setores técnicos. Estes setores agrupavam as empresas associadas em quatro regiões básicas e os critérios para divisão foram, basicamente, a área de atuação da empresa e os programas de pesquisa em desenvolvimento das associadas. Neste mesmo ano, o IPEF contava com 29 empresas associadas, 80 funcionários, sendo 12 próprios (IPEF, 1981).

Entre os anos de 1979 e 1981, o IPEF passou por um período de reavaliação de seus objetivos. Em fevereiro de 1981, os professores do Departamento de Silvicultura, DS/ESALQ, lançaram o documento "Algumas considerações sobre o relacionamento DS/IPEF" (Ferreira 1993).

Segundo Barrichello (1993), do começo dos anos 1980, destacaram-se os trabalhos nas áreas de:

a) interação genótipo-ambiente;

b) produção de híbridos;

c) planejamento florestal;

d) rotações sucessivas de eucalipto;

e) monitoramento de insetos em florestas;

f) CCGMPT (Centro de Conservação Genética e Melhoramento em Pinheiros Tropicais);

g) mecanização florestal;

h) rede científica USP/IPEF/informatização;

i) silvicultura de nativas.

Em meados de 1981, a estrutura do IPEF foi modificada, sendo que o diretor científico acumularia a vaga de diretor administrativo e o diretor técnico ficaria com a função adicional de assessor de pesquisa. Foi instituída uma comissão de desenvolvimento de pesquisa, formada por dois professores por setor, responsáveis por assessorar a diretoria científica (IPEF, 1982). 
Foram também consolidados, em 1982, os projetos cooperativos, que tinham por objetivo:

a) racionalizar as pesquisas entre associadas, minimizando o número de ensaios com os mesmos objetivos;

b) promover ações conjuntas de várias entidades para a resolução de objetivos comuns;

c) dar direcionamento às pesquisas prioritárias para as associadas e a universidade;

d) fornecer informações técnicas ou materiais para nivelamento para as associadas;

e) possibilitar a visão global das principais linhas de pesquisa desenvolvidas e;

f) apresentar novas filosofias de pesquisa a serem desenvolvidas.

Em 1984/85, o IPEF tinha como metas (IPEF, 1984) e (IPEF, 1985):

a) concentrar seus esforços em programas cooperativos de melhoramento genético e manejo florestal de pinheiros e eucaliptos;

b) redução do número de engenheiros do IPEF para três, que assumiriam as responsabilidades nas áreas de melhoramento, manejo e biometria e inventário florestal; o IPEF deixa de atender às associadas segundo a divisão regional e passa a fazê-lo por programas;

c) elaboração de um plano estratégico para o IPEF;

d) desenvolvimento do programa de manejo de brotações de Eucalyptus;

e) meio ambiente e qualidade (certificação florestal).

Em 1986, foram realizadas reuniões com o objetivo de direcionar as linhas de pesquisa. Os temas resultantes foram:

a) exportação de nutrientes;

b) segunda rotação (interação de espécie e espaçamento);

c) estudos sobre época e idade de corte;

d) implantação de métodos de padronização de análise e; 
e) tratos culturais, antes e pós-corte.

Já em 1992, foi alterado o estatuto social, criando-se o Conselho Técnico Científico e a Gerência Executiva, permitindo uma maior aproximação entre os professores e as empresas cooperadas. Foram também feitas mudanças no organograma, reduzindo os estágios hierárquicos. Nota-se, neste período, uma grande preocupação no desenvolvimento dos programas cooperativos.

No período de 1995/1996, destacam-se assuntos voltados para a área de ambiência florestal, tais como regeneração de áreas de preservação, monitoramento de bacias hidrográficas e indicadores de manejo sustentável.

Em 2000, começando a comemoração dos seus 35 anos, o IPEF lançou o livro "A Floresta e o Homem", que retrata a história do IPEF desde sua fundação em 1968. Nesse ano, o IPEF tinha 23 empresas associadas (Figura 2).

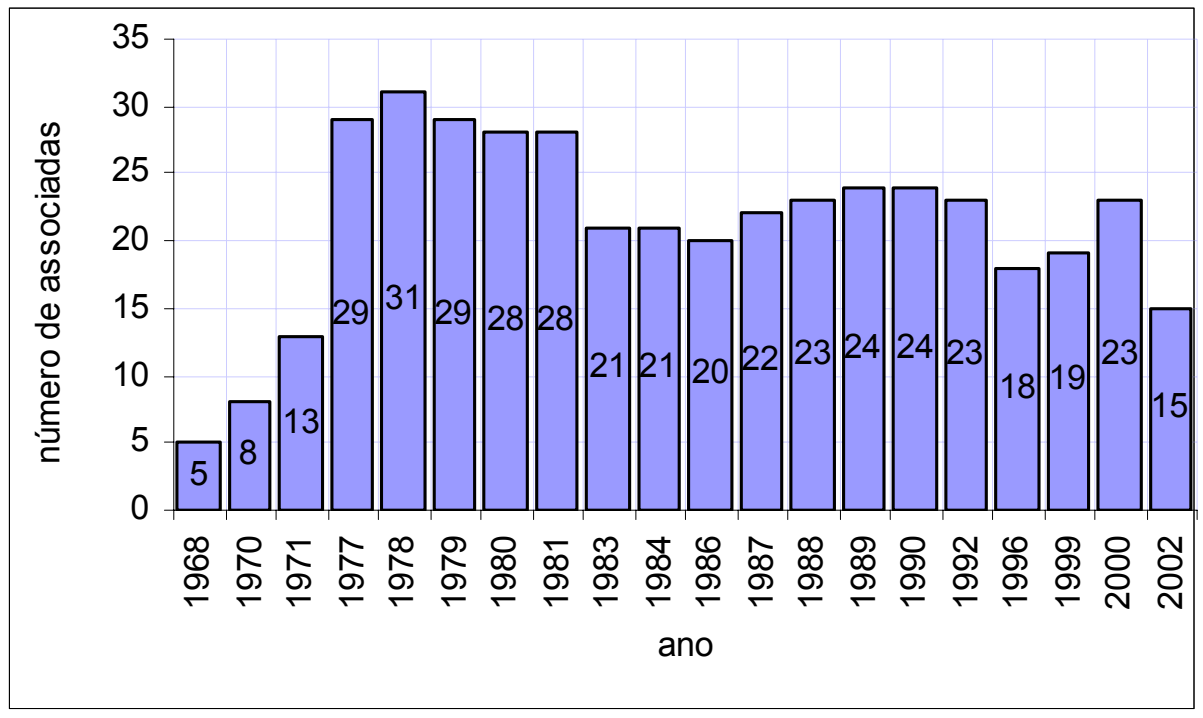

Figura 2 - Evolução do número de empresas associadas ao IPEF Fonte: Relatórios técnicos do IPEF 
Em 2002, o IPEF dividia suas atividades técnico-científicas em seis grandes áreas, que até hoje são responsáveis pelos projetos específicos e programas temáticos (IPEF, 2002):

a) silvicultura e manejo florestal

b) proteção florestal;

c) conservação, educação e legislação ambiental;

d) modelagem e monitoramento ambiental em bacias hidrográficas;

e) produtos florestais;

f) celulose e papel.

Leão (2000) descreve que a estratégia de atuação do IPEF está voltada atualmente para a difusão de informações, a formação de recursos humanos, o desenvolvimento de programas/projetos e o fornecimento de material genético.

A Figura 3 esquematiza a atual estrutura operacional do IPEF.

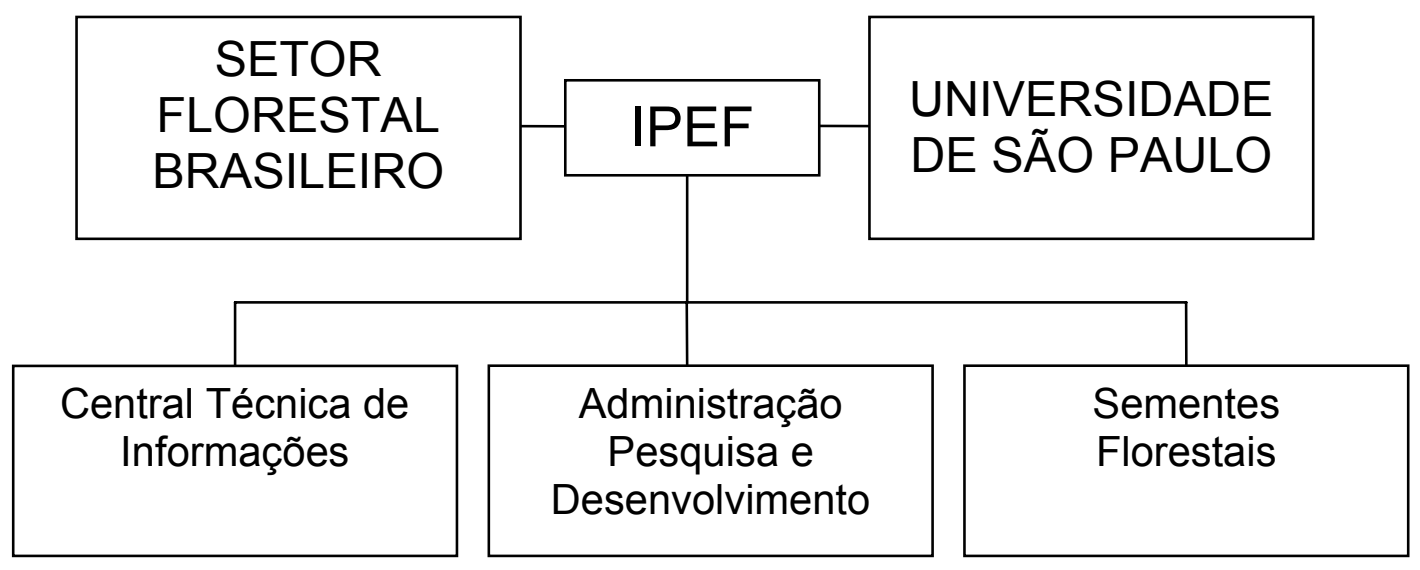

Figura 3 - Estrutura operacional do IPEF

Fonte: Leão (2000) 


\subsubsection{A contribuição do IPEF para o desenvolvimento florestal brasileiro}

O Instituto de Pesquisas Florestais (IPEF), desde a sua criação, vem interagindo com o setor florestal brasileiro e internacional, gerando e disseminando tecnologias que possibilitaram o aumento da produtividade e a qualidade das florestas.

O IPEF desempenhou um importante papel na distribuição do material genético de Eucalyptus proveniente do Horto Florestal de Rio Claro (Leão, 2000).

Em 1969, as empresas Champion Papel e Celulose Ltda e Duratex S.A., preocupadas com a qualidade genética e fisiológica das sementes produzidas pelo IPEF/FEPASA, trouxeram ao Brasil o professor australiano L.D. Pryor que, após tomar conhecimento dos problemas, sugeriu a introdução de novas procedências australianas das sementes para as principais espécies e a introdução de novas espécies e procedências visando à ocupação das novas áreas ecológicas para plantios. Os resultados obtidos pela Champion Papel e Celulose e pela Duratex S.A. com a introdução do E.grandis, procedência Coff's Harbour/New South Wales/ Austrália, ocasionaram:

a) a intensificação dos estudos das procedências das sementes das espécies de eucaliptos mais importantes e;

b) a criação do programa IBDF/ FAO/ PNUD/ PRODEPEF.

Também em 1969 foi implantado um programa de monitoramento de pragas, o qual permanece até os dias atuais, promovendo a conscientização e capacitação de profissionais nas empresas.

Nos anos 1970, tiveram início os estudos sobre melhoramento florestal em espécies de rápido crescimento, procurando detectar as espécies mais adequadas e as procedências mais produtivas. Como a base genética das florestas disponíveis era muito baixa, procurou-se, por meio de técnicas de melhoramento, o aumento da qualidade genética dessas populações, sendo, então, a base dos pomares de sementes montados pelas empresas. 
Segundo Poggiani et al. (1996), pode-se considerar que uma das grandes preocupações do IPEF na época foi a de estabelecer populações bases adequadas ao programa de melhoramento, por meio da análise de populações existentes, e da necessidade da importação e/ou coleta de material na região de ocorrência natural da espécie. No período de 1970 a 1984, cerca de 2.200 lotes de sementes de 55 espécies, envolvendo espécies/ procedências/progênies foram introduzidos no Brasil. $O$ material genético introduzido nesse período foi extremamente importante para a continuidade e estabilidade do programa de melhoramento.

No período de 1976 a 1990, foram comercializadas pelo IPEF/FEPASA 50 toneladas de sementes. Estima-se que, nesse período, tenham sido importadas outras 120 toneladas. A importação generalizada de sementes, sem nenhum controle ou certificação adequada, ocasionou o plantio de extensas áreas sem nenhum valor silvicultural. Em 1977, o IBDF (atual IBAMA) criou a "Comissão de Controle de Sementes" para os florestamentos e reflorestamentos incentivados, com o objetivo de controlar e certificar as áreas de produção de sementes. A certificação dessas áreas, em sua maioria, foi feita pelo IPEF, assessorado pelos professores do Departamento de Ciências Florestais da ESALQ (Poggiani et al., 1996). O IPEF também trabalhou no cadastramento de todas as populações de Eucalyptus implantadas no Brasil, por entidades privadas e estatais. Este trabalho foi disponibilizado para as associadas para auxílio no programa de melhoramento.

Os primeiros estudos sobre ciclagem de nutrientes em plantações de Pinus e Eucalyptus são da década de 1970. Eles foram instalados para responder a diversas críticas sobre o emprego destas espécies em plantios florestais. Por meio deles, verificou-se a real contribuição destas árvores para a recuperação da camada orgânica do solo. Posteriormente, devido à crescente preocupação com a manutenção da produtividade florestal na segunda rotação de Eucalyptus, os experimentos foram direcionados para a quantificação da exportação dos nutrientes por ocasião da exploração dos talhões e em manejos 
específicos para a segunda rotação, principalmente em florestas plantadas sobre solos arenosos e de baixa fertilidade, reduzindo o investimento em reforma destes povoamentos.

Outro tema estudado foi a adoção, por parte de algumas empresas, principalmente aquelas que usam o Eucalyptus como fonte energia, de rotações mais curtas e plantios mais adensados. Com este manejo, as empresas cortavam suas florestas em aproximadamente dois anos. O IPEF mostrou, por meio de experimentos instalados, que a retirada de nutrientes do solo era muito grande e a sustentabilidade dos plantios muito ameaçada. Em função disso, as empresas começaram a adotar rotações maiores e aumento do espaçamento.

A preocupação com a sustentabilidade das florestas provocou uma demanda por estudos na área de cultivo mínimo. O IPEF formou um grupo de estudos com o objetivo de entender a dinâmica dos nutrientes e do desenvolvimento de novos processos.

Os primeiros avanços na área de cultura de tecidos para clonagem de Eucalyptus obtidos pelo IPEF datam de 1974, tendo, em 1976, sido introduzidas técnicas de micropropagação e cultura "in vitro", hoje largamente utilizadas por grandes empresas do setor de papel e celulose. No setor de produção de mudas, introduziu-se a utilização dos sacos plásticos como embalagens para as mudas. Ao mesmo tempo, mostraram-se as vantagens da semeadura direta nas embalagens plásticas em relação à repicagem e à semeadura direta em torrão paulista. O período de formação das mudas foi drasticamente reduzido. Novos aparelhos para a semeadura direta (semeadores) foram desenvolvidos, visando reduzir o consumo de sementes e a necessidade da eliminação de mudas excedentes por embalagem.

Os estudos dos aspectos ambientais envolvidos na produtividade florestal e na manutenção do equilíbrio biológico tiveram, em 1979, seu efetivo começo, tendo o IPEF papel importante de conscientização das associadas sobre a importância do tema (IPEF, 1979). 
Nos anos de 1980, a preocupação com qualidade passou a ter mais importância, sendo um dos maiores problemas a ausência de estudos para avaliar a qualidade da madeira. Passou-se, então, a adotar a densidade como o mais importante fator para analisar a qualidade da madeira. Com o passar dos anos, outras variáveis vêm sendo adotadas para medir a qualidade, tais como a quantidade de fibras por grama, as características químicas da madeira e da própria fibra. A necessidade da indústria de padronização das características da madeira fez o IPEF investir em um grande número de trabalhos técnicos e científicos nesta linha na década de 1980.

Os estudos efetuados a partir de 1977 mostraram a viabilidade tecnológica de aproveitamento, na indústria, de painéis compensados de Eucalyptus, desde que fossem efetuados estudos para diminuir as rachaduras de topo, ocasionadas pelas tensões internas provenientes do rápido crescimento destas árvores.

Foram também realizados pelo IPEF os primeiros ensaios físicomecânicos para avaliação das qualidades do Eucalyptus, na obtenção de valores de referência em comparação com as tradicionais madeiras de lei.

A preocupação ambiental voltou à cena na década de 1990, com os estudos de monitoramento ambiental e a procura por indicadores de sustentabilidade ambiental. O IPEF teve um importante papel nestas áreas, acompanhando e estudando o maior complexo de microbacias implantado no Brasil e ajudando na quebra de valores com relação ao uso da água pelas essências exóticas, principalmente o Eucalyptus.

O IPEF contribuiu também para a utilização de resíduos decorrentes do processo de produção de celulose. Foram estudadas as dosagens e a forma de aplicação destes resíduos no campo, reduzindo o custo final e promovendo uma maior conservação do solo, além do destino racional destes resíduos, reduzindo-se o impacto ambiental.

Nos dias atuais, destacam-se os trabalhos conduzidos nas áreas de modelos ecofisiológicos, objetivando o entendimento dos aspectos físicos, 
biológicos e fisiológicos que governam a produtividade florestal e dos trabalhos de certificação de cultivares. A obtenção do primeiro certificado do Brasil para o gênero Eucalyptus foi feita numa parceira do IPEF com a International Paper do Brasil.

A Tabela 2 resume os projetos cooperativos e programas temáticos do IPEF, com os respectivos objetivos.

Tabela 2. Evolução dos programas cooperativos e programas temáticos do IPEF

\begin{tabular}{|c|c|c|}
\hline Ano & Projeto & Principais objetivos \\
\hline 1987 & $\begin{array}{l}\text { Centro de Conservação } \\
\text { Genética e Melhoramento de } \\
\text { Pinheiros Tropicais -CCGMPT }\end{array}$ & $\begin{array}{l}\text { - Conservação de material genético na } \\
\text { forma de bancos clonais; } \\
\text { - Melhoria da produtividade e qualidade da } \\
\text { madeira; } \\
\text { - Obtenção de sementes melhoradas pela } \\
\text { transformação dos testes de progênie em } \\
\text { pomar de sementes por muda. }\end{array}$ \\
\hline 1987 & Interação Genótipo/Ambiente & $\begin{array}{l}\text { - Estudos da interação genótipo ambiente } \\
\text { para utilização no programa de } \\
\text { melhoramento. }\end{array}$ \\
\hline 1987 & Produção de Híbridos & $\begin{array}{l}\text { - Estudos do comportamento e produção de } \\
\text { híbridos intra e interespecíficos. }\end{array}$ \\
\hline 1988 & Planejamento Florestal & $\begin{array}{l}\text { - Discussão e aprimoramento de técnicas } \\
\text { de planejamento florestal. }\end{array}$ \\
\hline 1989 & $\begin{array}{l}\text { Rotações Sucessivas de } \\
\text { Eucalyptus }\end{array}$ & $\begin{array}{l}\text { - Estudar os fatores edáficos e operacionais } \\
\text { que afetam a brotação de Eucalyptus. }\end{array}$ \\
\hline 1988 & $\begin{array}{l}\text { Monitoramento de Insetos em } \\
\text { Floresta (PCMIF) }\end{array}$ & $\begin{array}{l}\text { - Estudar a dinâmica populacional e } \\
\text { controle dos principais insetos. }\end{array}$ \\
\hline 1989 & $\begin{array}{l}\text { Programa Cooperativo de } \\
\text { Mecanização Florestal }\end{array}$ & $\begin{array}{l}\text { - Treinamento e Desenvolvimento de } \\
\text { equipamentos para colheita. }\end{array}$ \\
\hline 1992 & $\begin{array}{l}\text { Silvicultura de Espécies Nativas } \\
\text { (PCNAT) }\end{array}$ & $\begin{array}{l}\text { - Promover o desenvolvimento científico e } \\
\text { tecnológico da silvicultura de espécies } \\
\text { nativas. }\end{array}$ \\
\hline 1993 & $\begin{array}{l}\text { Programa Temático de } \\
\text { Qualidade da Madeira }\end{array}$ & $\begin{array}{l}\text { - Proceder a uma ampla avaliação das } \\
\text { características da madeira e suas } \\
\text { correlacõos com os processos industriais. }\end{array}$ \\
\hline 1995 & $\begin{array}{l}\text { Programa Temático sobre } \\
\text { Cultivo Mínimo (PTCM) }\end{array}$ & - Manutenção da produtividade florestal. \\
\hline 1995 & $\begin{array}{l}\text { Programa Temático de } \\
\text { Desenvolvimento do Programa } \\
\text { SPRING-FORXCEL }\end{array}$ & - Utilização de SIG na área florestal. \\
\hline
\end{tabular}


Tabela 2. Evolução dos programas cooperativos e programas temáticos do IPEF

\begin{tabular}{|c|c|c|}
\hline Ano & Projeto & Principais objetivos \\
\hline 1996 & $\begin{array}{l}\text { Programa Temático de Manejo } \\
\text { Integrado de Pragas - (PCMIP) } \\
\text { (ex PCMIF) }\end{array}$ & $\begin{array}{l}\text { - Estabelecer o manejo integrado de } \\
\text { pragas nas empresas do setor florestal. }\end{array}$ \\
\hline 1997 & $\begin{array}{l}\text { Programa Temático de } \\
\text { Silvicultura e Manejo (PTSM) }\end{array}$ & $\begin{array}{l}\text { - Embasar científica e tecnicamente as } \\
\text { tomadas de decisões operacionais } \\
\text { necessárias para aumentar e manter a } \\
\text { produtividade florestal. }\end{array}$ \\
\hline 1989 & $\begin{array}{l}\text { Rede de Monitoramento } \\
\text { Ambiental em Microbacias - } \\
\text { (ReMAM) }\end{array}$ & $\begin{array}{l}\text { - Estabelecer indicadores hidrológicos de } \\
\text { manejo sustentável; estabelecer modelos } \\
\text { de funcionamento de microbacias. }\end{array}$ \\
\hline 1996 & $\begin{array}{l}\text { Programa Temático Boro em } \\
\text { Eucalyptus (PTBORO) }\end{array}$ & $\begin{array}{l}\text { - Estudar a relação do boro com a } \\
\text { produtividade florestal. }\end{array}$ \\
\hline 1996 & $\begin{array}{l}\text { Programa Temático de } \\
\text { Educação, Conservação e } \\
\text { Legislação ambiental (PTECA) }\end{array}$ & $\begin{array}{l}\text { - Desenvolver projetos na área de } \\
\text { educação, conservação e legislação. }\end{array}$ \\
\hline 1992 & $\begin{array}{l}\text { Programa Temático em } \\
\text { Silvicultura Clonal e Viveiros } \\
\text { Florestais (PTCLONE) }\end{array}$ & $\begin{array}{l}\text { - Desenvolvimento de tecnologia aplicada à } \\
\text { clonagem. }\end{array}$ \\
\hline 1994 & $\begin{array}{l}\text { Programa de Engenharia de } \\
\text { Sistemas de Qualidade (PESQ) }\end{array}$ & - Desenvolvimento operacional \\
\hline 1998 & $\begin{array}{l}\text { Programa Temático em Produtos } \\
\text { Florestais (PRODFLOR) }\end{array}$ & $\begin{array}{l}\text { - Desenvolvimento de projetos na área de } \\
\text { produtos florestais. }\end{array}$ \\
\hline 2000 & $\begin{array}{l}\text { Programa de Proteção Florestal } \\
\text { (PROTEF) (ex PCMIP) }\end{array}$ & $\begin{array}{l}\text { - Atender à demanda das empresas nas } \\
\text { áreas de proteção, pragas e doenças. }\end{array}$ \\
\hline 2000 & $\begin{array}{l}\text { Programa de Monitoramento e } \\
\text { Modelagem de Bacias } \\
\text { Hidrográficas (PROMAB) (ex } \\
\text { ReMAM) }\end{array}$ & $\begin{array}{l}\text { - Estabelecer indicadores hidrológicos de } \\
\text { manejo sustentável; estabelecer modelos } \\
\text { de funcionamento de microbacias. }\end{array}$ \\
\hline 2001 & $\begin{array}{l}\text { Brasil Eucalyptus Potencial } \\
\text { (BEPP) }\end{array}$ & $\begin{array}{l}\text { - Desenvolver projetos para descrever e } \\
\text { testar os fatores que determinam o } \\
\text { crescimento das plantações de } \\
\text { Eucalyptus. }\end{array}$ \\
\hline
\end{tabular}

Fonte: Relatórios Técnicos do IPEF

Além de benefícios indiretos, como acesso a tecnologias e transferência de conhecimento dos pesquisadores e de servir de fórum para discussão de problemas específicos, podem ser destacados os principais benefícios gerados por estes programas:

- desenvolvimento de sistemas, técnicas de controle e manejo de pragas florestais, como formigas e Scolytidae;

- aprimoramento de práticas silviculturais que visam ao aumento e à sustentabilidade da produtividade florestal; 
- estudo de manejo em talhadia de Eucalyptus;

- estudos voltados para a ciclagem de nutrientes, fertilização, absorção de nutrientes, matocompetição e modelagem da água em povoamentos florestais;

- desenvolvimento e adaptação de equipamentos;

- utilização de resíduos na fertilização;

- demonstração dos efeitos ambientais do Eucalyptus para a sociedade;

- inclusão de parâmetros hidrológicos nos sistemas de monitoramento da sustentabilidade;

- desenvolvimento de conceitos para análise da biodiversidade;

- estudo de manejo para regeneração e recuperação das áreas de preservação permanente;

- definição de protocolos e treinamento de técnicas de propagação "in vitro" e manejos alternativos para multiplicação de clones;

- definição de estratégias clonais;

- desenvolvimento de técnicas de extração e beneficiamento da matériaprima;

- estudos do potencial de produção de madeira para serraria e manejo específico para serraria;

- conservação de material genético na forma de bancos clonais;

- produção de híbridos.

Mantendo sua missão de agente difusor do conhecimento e extensão, o IPEF vem, ao longo dos anos, promovendo inúmeros eventos, cursos, reuniões, "workshops", simpósios e seminários, envolvendo técnicos do Instituto e profissionais ligados às empresas.

Entretanto, uma das maiores contribuições do Instituto até hoje foi o envolvimento entre professores e técnicos da universidade e das empresas florestais, fazendo um elo de ligação entre o conhecimento e a aplicação. Fez 
também com que houvesse uma necessidade constante de aperfeiçoamento técnico, profissional e empresarial.

\subsection{Evolução das pesquisas na International Paper do Brasil}

A International Paper do Brasil é uma empresa produtora de papéis de imprimir e escrever e produtos de madeira utilizando sua base reflorestada como fonte de matéria-prima ou como geradora de recursos. Com matriz nos Estados Unidos, a empresa iniciou suas atividades no Brasil no município de Mogi Guaçu, SP, em 1960, tendo expandido seus negócios para outras regiões do país. Em 1988, iniciou um grande projeto florestal na região de Três Lagoas, MS; em 1996 adquiriu o controle acionário da Amapá Florestal e Celulose S/A (Amcel), no estado do Amapá, produtora de cavacos de pinus para o mercado externo e, em 1998, passou a controlar a Indústria de Papel Arapoti Ltda. (Inpacel), única empresa da América Latina a produzir papel revestido de baixa e média gramatura, para suprir o mercado gráfico nacional e internacional.

A Empresa começou a investir em pesquisa florestal na segunda metade da década de 1960, tendo sido uma das fundadoras do IPEF. Em 1994 criou o Departamento de Tecnologia Florestal visando o aumento da produtividade e qualidade de suas florestas.

Gerencia, hoje, cerca de 210.000 ha de florestas plantadas e 320.000 ha de florestas naturais nos estados de São Paulo, Paraná, Amapá, Mato Grosso do Sul e Minas Gerais.

Atualmente, a Pesquisa Florestal desenvolve trabalhos nas áreas de biotecnologia, melhoramento genético, clonagem, proteção e manejo florestal em todas as áreas de atuação da empresa, tendo como estratégia o desenvolvimento de pesquisas utilizando sua estrutura de pessoal e laboratórios e a parceria com diversos centros ou institutos de pesquisa, tais como o IPEF, a Fundação de Pesquisas Florestais (FUPEF) e a Sociedade de Investigações Florestais (SIF). 


\subsubsection{Melhoramento genético}

Segundo Freitas et al. (1983), o programa sexuado de Eucalyptus, no qual a semente é o elemento de propagação, teve início na empresa em 1967, com a importação dos primeiros lotes de semente de E. grandis provenientes de Bonville Coff's Harbour, Austrália. Esta população deu origem às áreas produtoras de sementes (APS) dos municípios de Aguaí (2) e Mogi Guaçu (2), ambos no estado de São Paulo. As APSs foram formadas (desbastadas) em 1972, utilizando-se os critérios e as orientações do IPEF. Para continuar o programa com E. grandis, 140 árvores superiores foram selecionadas. Em 1978, foi estabelecido um pomar de sementes no município de Mogi Guaçu com enxertos das árvores selecionadas. Os primeiros ensaios de progênie de polinização livre mostraram variações genéticas expressivas para o crescimento e retidão do tronco, permitindo a predição de ganhos genéticos significativos. A variação da densidade básica da madeira no âmbito de árvores superiores e de progênie indicou a possibilidade de inclusão desta característica no segundo ciclo de seleção.

Já o programa de melhoramento de E. urophylla teve início em 1969, por meio de uma parceria com o IPEF, selecionando 30 árvores superiores no Horto Florestal de Rio Claro (SP). Neste período, foram realizadas enxertias por borbulhia e, com os enxertos resultantes, o pomar de sementes foi instalado no município de Casa Branca, SP. A enxertia por borbulhia não foi bem sucedida, havendo perda de enxertos da maioria dos clones, restando somente quatro clones com número variável de enxertos. Devido aos problemas de perda de material genético, o pomar foi enriquecido, em 1973, com enxertos de 10 árvores das trinta previamente selecionadas, utilizando-se, agora, o método de enxertia por garfagem de fenda cheia. Em função dos bons resultados com o método de enxertia por garfagem, o pomar foi novamente reinstalado em 1974/1976, com as trinta árvores originais. Este trabalho foi realizado em convênio com a ESALQ/IPEF. Os novos clones foram introduzidos ao lado do material anterior, formando um único pomar, instalado em duas etapas. Ao 
mesmo tempo, prevendo-se problemas de incompatibilidade entre cavalo e cavaleiro, ao lado do pomar, foi instalado o "Banco Clonal de E. urophylla", com enxertos das trinta matrizes selecionadas na população original de Rio Claro.

A formação dessa grande base genética propiciou o desenvolvimento de vários estudos, tais como os aspectos relacionados com a dispersão de pólen, de Pacheco et al. citado por Freitas et al. (1983), em um trabalho desenvolvido pela Champion em convênio com o Centro Energia Nuclear em Agricultura (CENA) e a USP. Os resultados mostraram que a dispersão de pólen foi muito longa, atingindo distâncias acima de $300 \mathrm{~m}$. Entretanto, a maior concentração foi observada numa faixa de $100 \mathrm{~m}$.

Os estudos sobre florescimento começaram em 1979 e foram feitos em convênio com a USP e a Universidade Estadual Paulista (UNESP). De acordo com Aguiar \& Kageyama ${ }^{2}$, os resultados mostraram que a frutificação e a produção de sementes nas áreas da empresa ocorrem durante todo o ano, sendo a maior freqüência de julho a janeiro, com picos em agosto e dezembro. Mora \& Ferreira (1980) obtiveram resultados similares com E. urophylla.

Paralelamente, em testes experimentais, foram realizados estudos envolvendo pomares de sementes, nos quais uma área de produção de sementes foi implantada utilizando-se diretamente as árvores superiores selecionadas para a produção de pólen. O resultado foi o estabelecimento de 40 grupos de produtores de sementes, em que cada árvore superior recebia pólen de cinco árvores dominantes próximas.

Estudos de seleções em testes de progênie têm sido conduzidos desde 1976. Basicamente, os testes procuram por estimativas da capacidade de combinação das árvores selecionadas (permitindo re-seleção de clones e instalação de pomares de 1,5 geração) e conhecimento da estrutura da população por meio da determinação dos parâmetros genéticos.

\footnotetext{
${ }^{2}$ AGUIAR, I.B.; KAGEYAMA,P.Y. Estudos sobre florescimento e frutificação em Eucalyptus grandis. Piracicaba: ESALQ/USP, 1980. p.12-40.
} 
A densidade básica da madeira foi outra característica estudada. As análises feitas em $E$. grandis com o IPEF mostraram resultados satisfatórios, não encontrando correlações significativas entre densidade básica e vigor das árvores selecionadas, mostrando a independência destas variáveis. A partir destes resultados, a densidade básica foi estudada no âmbito da progênie, procurando a inclusão no segundo ciclo de seleção.

O programa de hibridação na International Paper teve início em 1974, sob a orientação do Professor Mário Ferreira (Brigatti et al., 1983). O principal objetivo era a obtenção de híbridos inter e intraespecíficos. Para isso, foram desenvolvidas pesquisas nas linhas de (Gava \& Vieira, 1988):

a) armazenamento de pólen;

b) testes de germinação e;

c) métodos para polinização controlada.

A propagação assexuada (clonagem) foi um grande diferencial no processo produtivo florestal. Apesar de caracterizar-se por um método de multiplicação em que não há recombinação genética entre indivíduos, o uso da técnica permite compatibilizar os possíveis riscos com os benefícios inerentes da uniformidade. Segundo Viera et al. (1992) e Comério (1994), o programa de propagação vegetativa começou em 1981, quando os primeiros Eucalyptus foram enraizados. A primeira seleção de matrizes que considerava características silviculturais (crescimento e forma) foi feita em 1983, nos municípios de Mogi Guaçu, Aguaí e Brotas, totalizando 11.000 indivíduos selecionados para a clonagem. Esta seleção foi intensificada nos anos seguintes, incluindo variáveis como brotação e enraizamento, o que reduziu o número de árvores selecionadas para 2.600 indivíduos, que foram plantados em um banco clonal. Em 1985 foram instalados testes clonais usando 529 clones que apresentavam bom desenvolvimento volumétrico e forma, além de bons aspectos fitossanitários. Já em 1990 foram plantados, em escala comercial, os primeiros clones testados. Foram utilizados 88 clones diferentes, os quais eram provenientes de diferentes bases genéticas (Tabela 3). Nos anos 
seguintes, observou-se um aumento expressivo na área plantada com clones na empresa, principalmente devido à homogeneidade apresentada na madeira e à uniformidade dos plantios clonais.

Tabela 3. Base genética dos primeiros clones recomendados comercialmente pela empresa

\begin{tabular}{lcc}
\hline \multicolumn{1}{c}{ Material genético } & Número de clones & \% de plantio \\
\hline E. grandis & 31 & 35 \\
E. urophylla & 18 & 20 \\
E. saligna & 3 & 4 \\
Híbridos & 36 & 41 \\
Total & $\mathbf{8 8}$ & $\mathbf{1 0 0}$ \\
\hline
\end{tabular}

Fonte: Comério (1994)

A Tabela 4 mostra resumidamente a evolução da clonagem na International Paper do Brasil.

Tabela 4. Evolução da clonagem na International Paper do Brasil

\begin{tabular}{|c|c|}
\hline Período & Atividade \\
\hline $1983 / 1985$ & Seleção de 11.000 árvores superiores nos plantios comerciais \\
\hline $1985 / 1986$ & Propagação de 2.600 árvores - implantação de testes clonais \\
\hline \multirow[t]{2}{*}{$1986 / 1988$} & Análise dos testes clonais - seleção de 350 clones \\
\hline & Início das atividades de micropropagação \\
\hline \multirow[t]{3}{*}{$1988 / 1993$} & Plantios monoclonais macropropagados \\
\hline & Instalação de testes clonais macro e micropropagados \\
\hline & Instalação do projeto de análise tecnológica de clones \\
\hline \multirow[t]{3}{*}{$1993 / 1994$} & Aumento de testes clonais \\
\hline & Plantios monoclonais macro e micropropagados \\
\hline & Nova seleção de árvores superiores \\
\hline \multirow[t]{2}{*}{$1994 / 2004$} & Recomendação baseada em características tecnológicas \\
\hline & Consolidação do plantio clonal em grande escala \\
\hline
\end{tabular}




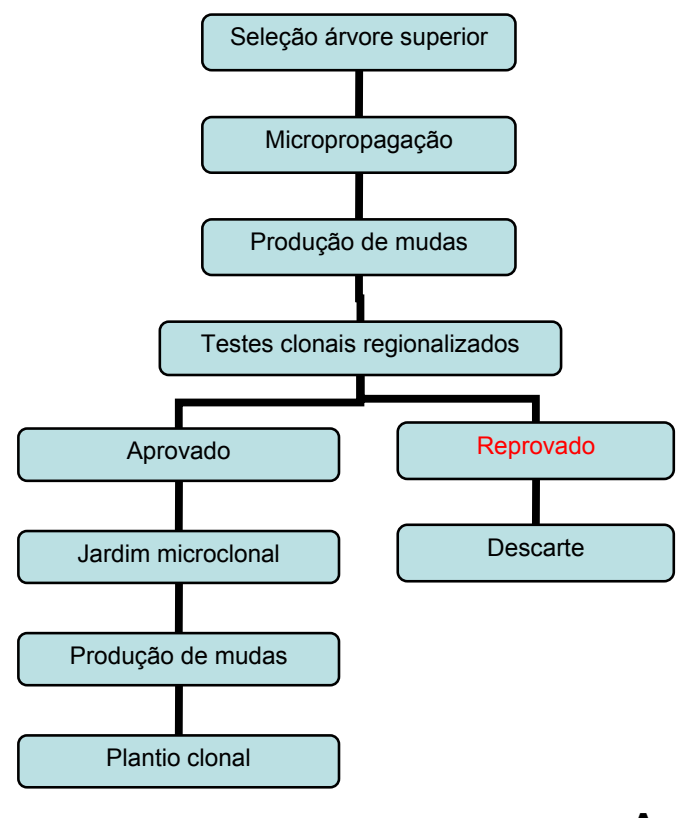

A

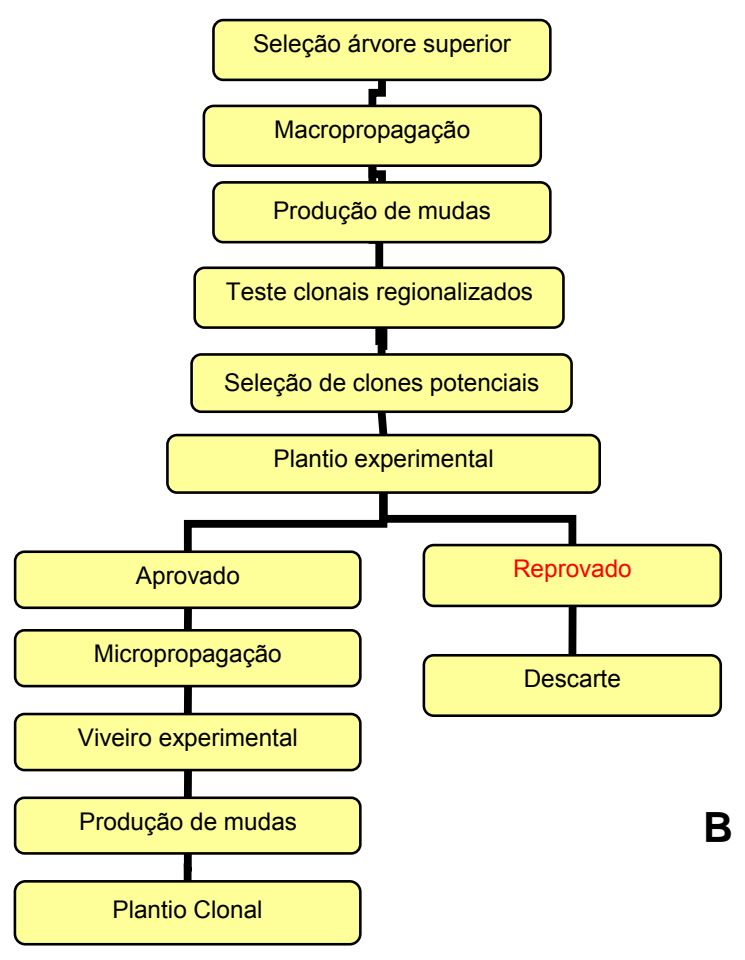

Figura 4 - Esquema geral da estratégia clonal da International Paper do Brasil (A) em 1996 e (B) em 2004

Fonte: Departamento de Tecnologia International Paper do Brasil 
A estratégia clonal da International Paper passou por várias modificações como apresentado na Figura 4.

A produção de mudas com alta qualidade para o plantio sempre foi um dos principais objetivos da empresa. Para a obtenção desse objetivo, foi criado um departamento responsável por desenvolver pesquisas no viveiro, o qual promoveu uma evolução no processo de produção de mudas. A Tabela 5 descreve esta evolução.

Tabela 5. Evolução do processo de produção de mudas na International Paper do Brasil.

\begin{tabular}{lll}
\hline Períodos & \multicolumn{1}{c}{ Método } & \multicolumn{1}{c}{ Propagação } \\
\hline $1965 / 1974$ & Torronete e torrão paulista & Semente \\
$1975 / 1979$ & Torrão paulista & Semente \\
$1980 / 1984$ & Torrão paulista e saco plástico & Semente \\
$1985 / 1989$ & Tubetes plásticos & Semente/clonagem \\
$1990 / 1994$ & Tubetes plásticos & Clonagem (jardim clonal) \\
$1995 / 1999$ & Tubetes plásticos & Clonagem (microjardim) \\
$2000 / 2004$ & Tubetes plásticos & Clonagem (hidroponia) \\
\hline
\end{tabular}

Apesar dos avanços obtidos na produção de mudas, muitas empresas deixaram em segundo plano a propagação vegetativa. Os grandes ganhos selecionando novos clones não eram mostrados quando multiplicados por estacas. Este efeito foi chamado de efeito "c", atribuído à falta de rejuvenescimento dos materiais.

A cultura de tecidos se torna uma ferramenta indispensável neste processo, permitindo, por meio de subcultivos, o rejuvenescimento dos materiais usados. Esta técnica visa à manipulação "in vitro", pela técnica da cultura de tecidos em frascos, de plantas de eucalipto. Pela cultura de tecidos, segmentos das plantas são desenvolvidos, transformando-se em novas plantas em meios de cultura apropriados. Plantas obtidas pela cultura de tecidos, denominadas clones, são geneticamente iguais às plantas que forneceram os 
segmentos cultivados "in vitro". Essa particularidade permite que a empresa estabeleça seus plantios clonais, formando uma floresta homogênea com características de interesse.

Campinhos et al. (1999) citam algumas vantagens da estaquia:

a) aceleração do programa de melhoramento, devido ao menor tempo para recomendação clonal;

b) maior facilidade de enraizamento de estacas e maior aproveitamento final;

c) redução do tempo de formação da muda no viveiro;

d) eliminação do jardim clonal;

e) maior homogeneidade dos plantios e;

f) eliminação de problemas ligados ao não rejuvenescimentos dos materiais.

A evolução da cultura de tecidos dentro da empresa pode ser observada na Tabela 6.

Tabela 6. Evolução da cultura de tecidos na International Paper do Brasil

\begin{tabular}{|c|c|c|c|c|}
\hline Ano & Enraizamento & Objetivo & $\begin{array}{c}\text { Aproveitamento } \\
(\%)\end{array}$ & $\begin{array}{c}\text { Custo } \\
\text { (US\$/mil) }\end{array}$ \\
\hline $1886 / 1993$ & "In vitro" & $\begin{array}{c}\text { Testes } \\
\text { Plantio } \\
\text { comercial }\end{array}$ & 34 & 800 \\
\hline $1993 / 1994$ & $\begin{array}{c}\text { Casa de } \\
\text { vegetação }\end{array}$ & $\begin{array}{l}\text { Testes } \\
\text { Jardim } \\
\text { Plantio } \\
\text { comercial }\end{array}$ & 60 & 430 \\
\hline 1994/ 1996 & $\begin{array}{c}\text { Casa de } \\
\text { vegetação }\end{array}$ & Microjardim & 75 & 135 \\
\hline $1997 / 2002$ & $\begin{array}{c}\text { Casa de } \\
\text { vegetação }\end{array}$ & Hidroponia & 90 & 120 \\
\hline $2003 / 2004$ & $\begin{array}{c}\text { Casa de } \\
\text { vegetação }\end{array}$ & $\begin{array}{c}\text { Área de } \\
\text { formação } \\
\text { de matrizes }\end{array}$ & 90 & 100 \\
\hline
\end{tabular}

Fonte: Departamento Tecnologia e Informações International Paper do Brasil 


\subsubsection{Manejo florestal}

Segundo Freitas et al. (1991), até a década de 1970, o uso de técnicas avançadas de manejo florestal, como a utilização de fertilizantes, redução do número de rotações e outras medidas silviculturais na condução de povoamentos de Eucalyptus, eram consideradas aplicações de baixo retorno e, portanto, dispensáveis.

Isso, evidentemente, podia ser explicado pela alta disponibilidade de terras, baixo preço da madeira, baixo índice de melhoramento genético e pelo pouco desenvolvimento de tecnologias silviculturais na época.

$\mathrm{Na}$ década de 1980 passou-se a adotar um manejo mais intensivo, verificado principalmente pela reforma dos povoamentos (Freitas, 1983). A limpeza da vegetação e dos resíduos da colheita é realizada pela queima e encoivara. O preparo de solo é feito com os implementos grade "bedding" e arado reformador. A fertilização passa a ser implementada e formulações de adubos NPK são aplicadas no plantio (250kg/ha de 10:20:10). Utiliza-se também a fosfatagem (yoorim, fosmag e faaps) em cobertura, aos três meses após o plantio e o NPK (150kg/ha de 15:00:15) em cobertura, aos 12 meses após o plantio. O controle de plantas daninhas é realizado por meio de gradagens sucessivas e manualmente, por capinas com enxada. O plantio é alinhado na direção do declive, de modo a facilitar a retirada da madeira colhida e o espaçamento praticado é de $2 \mathrm{~m} \times 2 \mathrm{~m}$.

A partir de 1982, passou-se a utilizar cinza nos solos arenosos, proveniente da caldeira para produção de energia a partir de casca e lenha fina de Eucalyptus da indústria, a partir de um trabalho com o IPEF (Freitas, 1985).

De 1990 a 1994 foram implementadas algumas tecnologias ou inovações:

a) Redução do número de rotações:

A queda da produção a partir da segunda rotação (23\%) e o aumento do número de falhas (22\%), associado à menor disponibilidade de madeira em 
áreas próximas às fontes consumidoras e ao surgimento de matérias mais produtivos e adaptados, viabilizaram reformas de povoamentos;

b) Uso de adubação orgânica, por meio da utilização de resíduos industriais

Utilizou-se a cinza da caldeira de biomassa como complemento nutricional em dose de 10 toneladas/ha aos 18 meses após o plantio;

c) Concentração de plantios na época de inverno

Observações de experimentos mostraram que os plantios realizados na época de verão apresentaram índice de falhas de 30\%. Já os plantios realizados no inverno apresentam um percentual de $10 \%$, reduzindo os custos de operação de plantio. Notou-se também que, neste período, houve uma menor infestação por ervas daninhas. Em média, esta decisão reduziu os custos de plantio em aproximadamente $6 \%$ (Freitas et al., 1991);

d) Aumento do espaçamento de plantio:

Os sítios mais produtivos passaram a ser plantados com espaçamento de $3 \mathrm{~m} \times 2 \mathrm{~m}$;

e) As operações de implantação eram gradagem, sulcamento e adubação e a reforma com arado reformador e bedding.

f) A fosfatagem aos três meses após o plantio é retirada, permanecendo apenas as adubações de plantio e aos 12 meses de idade.

g) O controle de ervas daninhas é realizado por gradagens sucessivas e capina manual. É iniciado o uso do herbicida como ferramenta de controle préemergente de ervas daninhas (2 litros/ha de Oxyflurfen).

A partir de 2004, os ambientes de produção passaram a ser subdivisões mais abrangentes, relativas a clima e relevo das áreas florestais. Foram criadas também as unidades de manejo, que são subdivisões dos ambientes de produção e se distinguem pelas diferentes produtividades encontradas nas florestas. As fertilizações passaram a ser específica para cada unidade de manejo e variam de acordo com as exportações de nutrientes, balanço nutricional e características físicas, químicas e físico-químicas de cada unidade. 
$\mathrm{Na}$ área de ordenamento, investimentos têm sido feitos desde a década de 1990, com o objetivo de criar ferramentas de apoio à tomada de decisão. Em 2003, a empresa começou a utilizar operacionalmente ferramentas de programação linear no ordenamento da produção florestal.

\subsubsection{Tecnologia da madeira}

Dentro do processo de aumento da competitividade no mercado de celulose e papel no Brasil e no mundo, torna-se cada vez maior a necessidade de produtos de alta qualidade, visando atender, cada vez, mais as necessidades dos clientes e, ainda, com preços mais competitivos no mercado.

A empresa usa, desde a década de 1980, informações de qualidade da madeira utilizadas no programa de melhoramento clássico e clonagem, porém, apenas em 2001 investiu na construção de um laboratório, visando obter informações para utilização em seu programa de melhoramento florestal. Para isso, o laboratório está equipado com equipamentos capazes de analisar densidade básica das madeiras, teores de extrativos, teores de lignina, teores de holocelulose das árvores e de rendimento de celulose dos materiais selecionados, e ainda realizar análise morfológica de fibras, como comprimento de fibra, largura de parede celular, espessura de fibra, largura de lúmen, entre outras.

Essas análises são de grande importância para os processos industriais, já que as informações geradas darão suporte à seleção de árvores que possuam, além de uma performance silvicultural satisfatória por meio da verificação dos níveis de produtividade no campo, performance industrial requerida, por meio de altos níveis de rendimento de polpa, baixo consumo de químicos durante os processos de deslignificação, seja durante o cozimento ou no branqueamento, e que produzam fibras com resistências e características morfológicas adequadas para a produção de papéis. 


\subsubsection{Colheita}

A empresa, preocupada com a disponibilidade de mão-de-obra específica para as operações de colheita florestal e a elevação dos custos das mesmas, vem, desde 1989, desenvolvendo um sistema mecanizado para a colheita de Eucalyptus (Freitas et al. 1993).

Segundo Freitas (1985), já em 1984 a colheita representava 23\% dos custos da madeira na fábrica. A Tabela 7 resume a evolução da colheita florestal na empresa ao longo dos anos.

Tabela 7. Evolução da colheita florestal na International Paper do Brasil

\begin{tabular}{cccc}
\hline Operação & 1960-1989 & Período & 1990-2000 \\
\hline Derrubada & $\begin{array}{c}\text { Machado/ } \\
\text { Moto-serra }\end{array}$ & $\begin{array}{c}\text { Feller Bell triciclo } \\
\text { Baldeio }\end{array}$ & $\begin{array}{c}\text { Feller esteira - braço } \\
\text { móvel }\end{array}$ \\
Traçamento & Carros de boi & Mini Skidders & $\begin{array}{c}\text { Skidders de grande porte } \\
\text { Garras traçadoras de } \\
\text { grande porte }\end{array}$ \\
Carregamento & Moto-serra & Garras traçadoras & $\begin{array}{c}\text { Mecânica de grande } \\
\text { porte }\end{array}$ \\
\hline
\end{tabular}

Fonte: Departamento de Colheita Florestal

Esta evolução pode ser constatada pelo aumento da produtividade na colheita, conforme Tabela 8.

Tabela 8. Evolução dos rendimentos de colheita florestal na International Paper do Brasil

\begin{tabular}{lc}
\hline Equipamento & Produtividade (arv/dia) \\
\hline Machado & 25 \\
Moto-serra & 100 \\
Feller Bell triciclo & 2.400 \\
Feller pneu - braço fixo & 4.480 \\
Feller esteira - braço móvel & 9.450 \\
\hline Fonte: Departamento de Colheita Florestal.
\end{tabular}

Fonte: Departamento de Colheita Florestal. 


\subsubsection{Ambiência}

Segundo Colli et al. (1989), já em 1989 a ambiência tinha as seguintes linhas de pesquisa dentro da empresa:

- recomposição das áreas degradadas de cerrado;

- recomposição de várzeas;

- plantio de essências nativas nas linhas de alta tensão para corredores de fauna.

O Departamento de Ambiência da empresa foi criado em 1993, com o objetivo de desenvolver projetos de educação ambiental e pesquisas nas áreas de floresta natural e de fauna. Para subsidiar pesquisas institucionais e científicas, o departamento conta com uma estrutura de laboratório e equipe técnica treinada. Em 2000, a empresa recebeu, para a fábrica de Mogi Guaçu, a certificação ISO 14000 (International Standardization for Organization) e, em 2002, foi criada a Reserva Particular do Patrimônio Natural (RPPN), numa área de 187 hectares.

Desde a sua criação, o departamento desenvolveu importantes pesquisas em parcerias com universidade, institutos de pesquisa, órgãos governamentais e não governamentais para melhores práticas de conservação. Recebeu também mais de 45.000 pessoas em seu programa de educação ambiental.

\subsection{A análise econômica do retorno à pesquisa}

Muitos governos e empresas vêm procurando critérios sistemáticos para definição e alocação dos recursos em pesquisa (Hellstrom \& Palo, 1994). A agricultura tem uma longa tradição em avaliar o retorno econômico do investimento em pesquisa. Bengston (1985), por exemplo, cita 83 avaliações econômicas em pesquisa agronômica. São ainda importantes os estudos feitos por Peterson (1969), Bengston (1984), Seldon (1987), Jakes \& Risbrudt (1988), 
Haygrenn et al. (1986), Hyde et al. (1992), Mckenney et al. $(1993,1997)$ e Davis et al. (1994).

Fishel (1981) identificou três usos para a avaliação de retorno da pesquisa na área florestal: (1) educação, (2) realocação de recursos e (3) desenvolvimento de políticas públicas. Callaham (1981) relata ainda os objetivos a serem atingidos pela pesquisa florestal:

a) reduzir os custos de produção;

b) aumentar a qualidade dos produtos e serviços;

c) reduzir incertezas de produção ou consumo;

d) aumentar a quantidade por unidade de tempo, recursos, etc;

e) aumentar a variedade ou oportunidade de acesso (novos produtos);

f) prevenir perdas (manutenção da produtividade);

g) aumentar a estabilidade da produção ou sistema de consumo e;

h) redistribuir custos ou benefícios da atividade florestal.

Bergston (1985) cita os principais métodos para avaliação de retornos em pesquisa. Os métodos são divididos em dois grandes grupos: pré-análise (avaliam as proposta de pesquisa) e pós-análise (pesquisas já efetuadas).

a) Pré-análises :

- Custo benefício

Método relativamente novo para análise de retorno usado por Fishel citado por Bengston (1985). Modelo baseado em computação, geralmente estruturado para coletar e processar informações relevantes para a alocação de recursos sobre situações consideradas como alto grau de incerteza. Este método é parecido com o de excedente de produção e consumo, sendo diferenciado apenas pelo fato de os estudos dos efeitos na produtividade serem estimados e projetados para o futuro com base nos dados passados. Estas projeções são freqüentemente obtidas com entrevistas e questionários dados aos pesquisadores com informações básicas de probabilidade de sucesso, 
tamanho do benefício, nível de adoção da tecnologia e custos. O óbvio problema deste método é que as respostas podem conter altas expectativas.

- Modelos de simulação

Em uma típica simulação de modelos, mudanças em produtividade são atribuídas a valores de investimentos públicos em pesquisa e outros fatores que podem afetam a produtividade. Os coeficientes usados nas variáveis do modelo geralmente vêm de estudos de funções de produção. Estimativas subjetivas das variáveis, como o tempo dos pesquisadores envolvidos, custos, probabilidade de sucesso e nível de adoção, devem alimentar o modelo. A validação dos resultados do modelo dependerá da acurácia destas estimativas. Um grande número de variáveis deve ser incorporado ao modelo, o que dificulta a implementação do mesmo.

\section{- Programação matemática}

A utilização desta técnica vem sendo limitada para investigação de alocação ótima de fundos de pesquisa. Utilizando-se as informações de ganhos esperados de custos e benefícios de pesquisa, o resultado obtido geralmente é a maximização dos resultados de alocação de recursos. Russel (1975) utilizou este método na pesquisa agrária.

- Modelos de ganho

Oferece um ranking de pesquisas alternativas ou áreas problemáticas. Esta técnica é usada primeiramente como uma ferramenta de gerenciamento, gerando uma básica alocação de recursos em diferentes níveis.

b) Pós-análises:

- Excedente de produção e consumo

O retorno ao investimento em pesquisa é medido pelas variações nos excedentes do consumidor e do produtor, bem como no excedente econômico. Tais variações são resultados do deslocamento (para baixo) da curva de oferta do produto, originada pelo deslocamento (para cima) da função de produção.

A análise é feita considerando que os custos ou benefícios correspondem às perdas ou ganhos de excedentes resultantes dos desvios em 
preços e quantidades, em relação àqueles que teriam ocorrido na ausência dos ganhos advindos da pesquisa. Essa relação é mostrada na Figura 5.

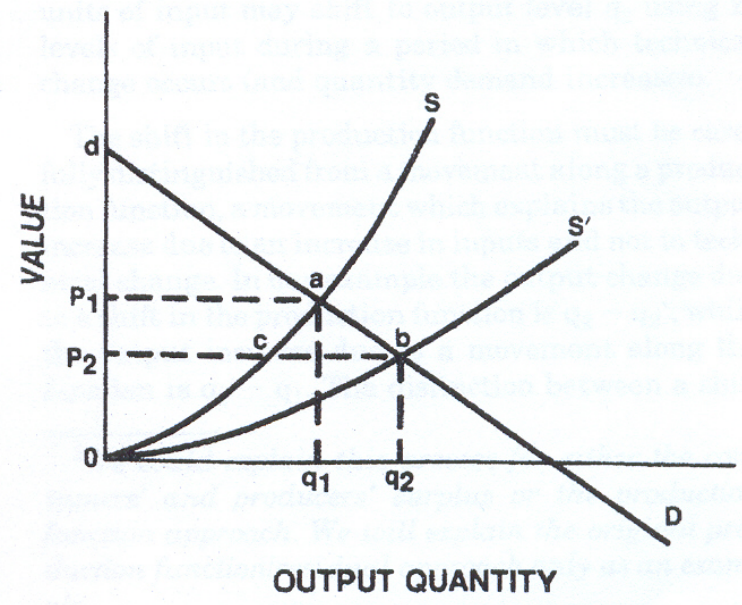

Figura 5 - Curva de excedente de produção e consumo Fonte: Bergston (1985)

O modelo mostrado na Figura 5 pode ser utilizado para mostrar os efeitos da mudança tecnológica sobre a quantidade produzida, os preços pagos pelos consumidores e os preços percebidos pelos produtores. As medidas de excedente econômico podem identificar o incremento da eficiência econômica (benefícios líquidos totais), assim como as distribuições dos benefícios entre consumidores e produtores (Alencar, 1999).

- Função de produção

A idéia é que as pesquisas podem produzir um aumento na quantidade de bens produzidos com uma quantidade fixa das tradicionais entradas. A contribuição das pesquisas para aumento da produtividade é estimada por uma função de produção em que as pesquisas são a variável independente. Análises de regressão tornam possível isolar os efeitos da pesquisa na produção, ao mesmo tempo em que as outras variáveis que afetam a produtividade são controladas (Figura 6). 
Este modelo mostrou-se útil para distinguir diferentes influências da investigação na produção agrária (Norton \& Davis 1981). Três principais aproximações vêm sendo utilizadas para especificar a variável pesquisa: o investimento anual em pesquisa, o nível de adoção ou inovações resultantes das pesquisas e o número de publicações encontradas.

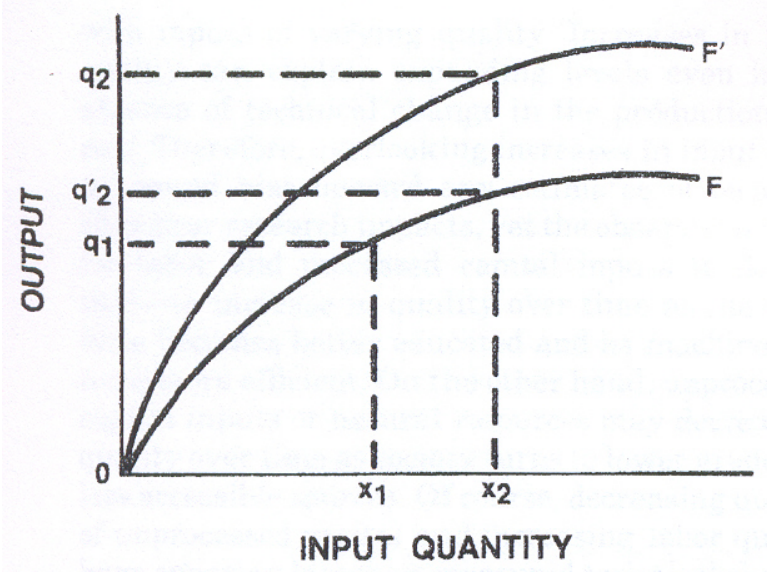

Figura 6 - Curva da função de produção

Fonte: Bergston (1985)

- Eficiência (adoção de tecnologias)

Usado para avaliar o aumento das informações resultantes da extensão em agricultura. O método é capaz de analisar a adoção de novas tecnologias produzidas por pesquisa. A descoberta do modelo é que o ajuste do coeficiente especificado é um vetor das variáveis ambientais, incluindo extensão, permitindo testar hipóteses que a extensão na agricultura é importante para mudanças nos níveis de investimento.

Apesar do grande número de alternativas para análise de retorno em pesquisa, os métodos de excedente de produção e consumo e função de produção são utilizados em $3 / 4$ dos trabalhos publicados (Bengston, 1985).

A enorme diferença deve-se a alguns fatores (Bengston, 1985): 
a) esses métodos foram usados nas primeiras avaliações de retorno em pesquisa na agricultura, sendo mais experimentados e desenvolvidos que os outros;

b) ambos os métodos são baseados em teoremas fundamentados e métodos de análise econômica aplicados;

c) existe um senso comum entre os pesquisadores de que os resultados destes métodos são consistentes e o tipo de informação produzida é importante para a tomada de decisões.

Bengston (1984), trabalhando com retorno à pesquisa em produtos estruturais de madeira e utilizando o método de produção e consumo, encontrou taxa de retorno de 18\%-22\%. Haygreen et al. (1986), para madeiras serradas e processo (papel e celulose), utilizando o mesmo método, encontraram taxas de retorno de $14 \%-36 \%$.

Porém, apesar dos modelos existentes, Jakes \& Risbrudt (1988), descrevem os seguintes problemas na avaliação de retornos sobre pesquisa:

a) o primeiro é que, em diversas áreas de pesquisa, é freqüentemente difícil, vincular de forma direta as mudanças dos recursos florestais com as inovações em pesquisa. Isso, em parte, é ocasionado em função do longo período de maturação de um projeto florestal, sendo difícil mensurar ou fazer prognose de ganhos antes do corte da floresta ou da influência de outras variáveis climáticas, biológicas e edafológicas. Observa-se também a dificuldade de extrair dos modelos de produção a causa do aumento de produtividades, existindo uma forte interação de diversas variáveis, não sendo o ganho somente fruto da adoção de uma determinada tecnologia;

b) produtos florestais têm diferentes destinos, sendo que a nova tecnologia pode não influir em um produto específico, ou como usualmente acontece sobre redução dos custos de produção;

c) uma vez detectado o impacto da inovação, será difícil atribuir-lhe rapidamente um valor; 
d) uma enorme quantidade de pesquisas é feita visando à manutenção dos atuais níveis de produtividade;

e) identificação dos potenciais usuários da nova tecnologia e projeções de adoção desta tecnologia. Prever níveis de adoção da nova tecnologia é um dos maiores desafios em avaliação de retorno para pesquisa;

f) existência de programas cooperativos entre os setores público e privado, no qual existem, além dos recursos financeiros, vários níveis de recursos humanos envolvidos;

g) inovações produzidas em outras empresas ou institutos são incorporadas ao modelo de produção sem investimento direto e;

h) a inexistência de dados confiáveis para os modelos propostos é fator de risco na aplicação dos modelos e na comparação dos resultados.

Apesar dos pontos descritos, evidenciam-se os enormes esforços sobre trabalhos com o objetivo de evidenciar ou mensurar o retorno ao investimento à pesquisa. 


\section{MATERIAL E MÉTODOS}

O trabalho procura avaliar os benefícios da pesquisa florestal realizada num modelo de integração universidade-empresa. A avaliação usa como referência o programa cooperativo de pesquisa mantido pela Universidade de São Paulo e pela International Paper do Brasil, no âmbito do convênio firmado entre a USP e o Instituto de Pesquisas Florestais (IPEF). Esta seção é desenvolvida em quatro diferentes partes. Essas partes são detalhadas a seguir e os resultados obtidos são apresentados na próxima seção deste trabalho.

\subsection{Projetos}

Neste item, descreve-se o processo de levantamento e classificação dos projetos realizados pela IP no âmbito do convênio IPEF/USP.

\subsubsection{Levantamento dos projetos}

A International Paper do Brasil (antiga Champion Papel e Celulose) foi uma das fundadoras do IPEF, em 1968. Possui quatro unidades industriais no Brasil, sendo objeto deste estudo a unidade de Mogi Guaçu, produtora de papéis de imprimir e escrever. Foram levantados todos os projetos de pesquisa coordenados pelo IPEF que envolveram a IP, no período de 1968 e 2003.

As fontes de dados para esse levantamento foram:

a) Biblioteca do IPEF

- publicações: dados publicados em alguns dos periódicos científicos do IPEF e ou outros eventos em que o IPEF estivesse representado; 
- relatórios do IPEF: relatórios editados pelo Instituto.

b) Acervo da empresa (acervo técnico): a empresa implantou, desde 2000, um acervo técnico para o armazenamento de todas as publicações, trabalhos, relatórios e projetos da área florestal. Foram levantados os materiais nas áreas técnicas, elaborando-se um sistema eletrônico de controle para inclusão e busca de informações. O trabalho está em fase de finalização dos cadastros.

A não padronização das informações na fonte permitiu apenas a coleta de informações básicas sobre cada projeto, contendo, no mínimo, título do projeto. área do projeto e data de início declarada do projeto. As informações completas com os dados obtidos encontram-se no item ANEXOS (Tabela 19).

\subsubsection{Classificação dos projetos}

Para uma análise mais profunda dos temas trabalhados e sua evolução no tempo, foi proposto um agrupamento dos projetos em grupos e subgrupos conforme sua área de atuação. Essa proposta está descrita na Tabela 9. 
Tabela 9. Proposta de classificação de projetos por grupos e sub grupos

\begin{tabular}{|c|c|c|}
\hline Grupos & Subgrupos & Áreas \\
\hline Ambiência & Conservação & $\begin{array}{l}\text { Ecologia, fauna, botânica, conservação, dendrologia } \\
\text { Educação ambiental, extensão, sociologia } \\
\text { Manejo de unidades de conservação, parques e } \\
\text { arborização }\end{array}$ \\
\hline \multirow[t]{4}{*}{ Manejo Florestal } & Produtividade & $\begin{array}{l}\text { Biometria, bioestatística, experimentação e inventário } \\
\text { Economia, política e legislação } \\
\text { Ordenamento, administração e análise de projetos }\end{array}$ \\
\hline & & $\begin{array}{l}\text { Fotointerpretação, SIG, geoprocessamento e } \\
\text { informática }\end{array}$ \\
\hline & $\begin{array}{l}\text { Adubação } \\
\text { Brotação } \\
\text { Desrama } \\
\text { Matocompetição } \\
\text { Espaçamento } \\
\text { Resíduos }\end{array}$ & Nutrição, fisiologia, fertilização, solos \\
\hline & Sistemas & $\begin{array}{l}\text { Consorciação, sistemas agroflorestais e } \\
\text { agrosilvipastoris }\end{array}$ \\
\hline Melhoramento & $\begin{array}{l}\text { Biotecnologia } \\
\text { Melhoramento } \\
\text { Testes clonais } \\
\text { Proteção } \\
\text { Sementes } \\
\text { Viveiro }\end{array}$ & $\begin{array}{l}\text { Biotecnologia, genética molecular, OGMs } \\
\text { Procedência e progênie } \\
\text { Entomologia, fitopatologia e incêndios } \\
\text { Produção, propagação, hibridação }\end{array}$ \\
\hline Mecanização & $\begin{array}{l}\text { Colheita } \\
\text { Mecanização }\end{array}$ & $\begin{array}{l}\text { Transportes, logística, operações silviculturais, } \\
\text { ergonomia }\end{array}$ \\
\hline $\begin{array}{l}\text { Tecnologia de } \\
\text { Produtos } \\
\text { Florestais }\end{array}$ & $\begin{array}{l}\text { Qualidade da } \\
\text { madeira } \\
\text { Tecnologia da } \\
\text { madeira }\end{array}$ & $\begin{array}{l}\text { Energia, carvão vegetal, química da madeira, óleos } \\
\text { essenciais e resinas, papel e celulose } \\
\text { Chapas, secagem, tratamento, processamento } \\
\text { mecânico }\end{array}$ \\
\hline
\end{tabular}

Para excluir possíveis erros na avaliação, em função do pequeno número de dados gerados, os mesmos foram ainda classificados em função da data de início do projeto, em períodos de cinco anos, como descrito na Tabela 10. 
Tabela 10. Classes de agrupamento de dados por períodos de cinco anos

\begin{tabular}{cl}
\hline Classes & Períodos \\
\hline 1 & $1965 / 1969$ \\
2 & $1970 / 1974$ \\
3 & $1975 / 1979$ \\
4 & $1980 / 1984$ \\
5 & $1985 / 1989$ \\
6 & $1990 / 1994$ \\
7 & $1995 / 1999$ \\
8 & $2000 / 2003$ \\
\hline
\end{tabular}

Para as bases que se mostrarem muito pequenas (poucas informações ou poucos anos), os dados permanecerão no formato original (ano a ano).

\subsection{Produtividade e qualidade}

Neste item, descreve-se como foram obtidas as informações de produtividade e qualidade da madeira.

\subsubsection{Levantamento das produtividades}

Para evidenciar o efeito dos avanços tecnológicos sobre a produtividade florestal, optou-se pelo levantamento das produtividades da floresta da empresa, por meio da composição de diversas séries temporais contínuas. Essas séries foram formadas com base em dados históricos de inventário florestal.

As parcelas de inventário usadas pela IP têm formato retangular $20 \times 20$ metros e são distribuídas aleatoriamente por todas as áreas de produção da empresa. De cada parcela são coletadas informações dendrométricas, as quais possibilitam a estimativa do volume produzido por hectare, além de informações de qualidade dos fustes, sobrevivência e outras. Essas parcelas são revisitadas a cada dois anos, possibilitando o acompanhamento de crescimento de diversos materiais em diferentes locais e épocas. Foram utilizadas, para a 
composição das séries, 16.142 parcelas de inventário de povoamentos em primeira rotação.

As séries temporais produziram tabelas de volume por hectare e de sobrevivência. Essas informações foram separadas por data de plantio e agrupadas em períodos de cinco anos, desde 1965 até 1995, com uma série extra de áreas plantadas em 1997, último período de dados para rotações completas. Para cada série foram ajustados dois modelos lineares simples, o primeiro utilizando como variável independente a idade e como variável resposta o volume por hectare de árvores sadias, o segundo tem como variável independente a idade e como variável resposta o percentual de sobrevivência, dado pela equação:

$$
\text { Sobrevivên cia }=\frac{\text { Fustes _ ha _ medição }}{\text { Fustes _estimados _totais }}
$$

onde :

$$
\begin{aligned}
& \text { Fustes_ha_medição }=\text { número de fustes vivos na medição; } \\
& \text { Fustes_estimados_totais }=\text { número potencial de fustes dado o espaçamento usado. }
\end{aligned}
$$

Os modelos lineares permitem estimar a taxa média de crescimento volumétrico e de sobrevivência. Essa taxa pode ser diretamente lida a partir do coeficiente angular do modelo (inclinação da tendência estimada). É a partir dessas taxas, obtidas para cada qüinqüênio de plantio, que se procurará evidenciar os efeitos dos avanços tecnológicos sobre a produtividade florestal.

Os valores foram gerados pelo Departamento de Planejamento e Inventário Florestal da IP. Foram utilizadas para cálculo do benefício apenas as variações positivas das produtividades, calculadas pela diferença entre a produtividade de um período e a produtividade no período anterior. 


\subsubsection{Outros levantamentos}

Foram levantadas, ainda, outras variáveis que podem evidenciar o aumento da produtividade e qualidade das florestas plantadas:

a) produção fabril no período de 1968 a 2003: produção em toneladas de celulose por ano (admt) ou (tonelada seca ao ar) obtida na área fabril da empresa;

b) histórico de plantio clonal: percentuais de plantios clonais efetivamente plantados na empresa por ano, obtido no Departamento de Tecnologia Florestal da IPB;

c) consumo específico: definido como a quantidade de madeira com casca necessária para a produção de 1 ton admt (air dry metric ton, ou tonelada seca ao ar) de celulose. Estes valores serão obtidos na área fabril da empresa;

d) aplicabilidade dos projetos: índice proposto para avaliação da aplicabilidade e ou adoção dos projetos desenvolvidos. Com base no levantamento dos projetos, foram classificados, pelos pesquisadores responsáveis da International Paper do Brasil (IPB), os projetos como aplicáveis (com alguma utilização e ou geração de conhecimento) e não aplicáveis (sem utilização ou geração de conhecimento);

e) rendimento em celulose: para a avaliação do desempenho da pesquisa na qualidade da madeira (madeira para processo de fabricação de celulose), será utilizado o rendimento em celulose, sendo este uma das variáveis pouco afetadas pelas mudanças de processo na fábrica. O rendimento do processo de produção de celulose é obtido pela razão percentual entre 0 peso absolutamente seco da polpa de celulose e o peso absolutamente seco da madeira utilizada.

$$
R \%=\frac{\text { Peso da polpa absolutamente seca }}{\text { Peso da madeira absolutamente seca }} x 100
$$


f) Preço da madeira: os custos levantados e utilizados são referentes aos valores reais de madeira pagos pela International Paper do Brasil a sua subsidiária florestal Chamflora Agroflorestal. Estes valores são compostos por madeiras provenientes de três diferentes fontes:

- áreas próprias: madeira proveniente de áreas próprias da empresa;

- parceria/fomento: madeiras provenientes de área de terceiros sob contrato de arrendamento ou participação e;

- mercado: madeiras provenientes do livre mercado.

Os valores são formados pela composição dos percentuais de abastecimento das três fontes acima citadas, podendo ocorrer variações de ano para ano, em função da composição de abastecimento.

g) custo pesquisa IP: metodologia empregada para estimar o custo médio por projeto, com base numa tabela de composição de custo com as seguintes informações:

- área;

- subárea;

- número de anos do experimento;

- número de medições do experimento;

- número de diárias gastas;

- custos de implantação;

- custos de manutenção;

- valor de administração.

Com base nos valores médios fornecidos pelos técnicos da empresa e assumindo-se que estes valores representam os experimentos efetuados por área e subárea, serão então quantificados, para cada experimento levantado, qual o valor investido pela empresa.

O resultado deste levantamento define a tendência de investimento ao longo dos anos. Esse valor será usado para cálculo dos valores investidos no 
IPEF em uma série maior de anos, utilizando como base os percentuais históricos de investimento em projetos

\subsection{Levantamento dos valores investidos}

Neste item são relacionados os levantamentos dos valores investidos no convênio e sua classificação, bem como os pagamentos feitos pela IPB ao IPEF com outros fins.

Os levantamentos dos valores foram obtidos na empresa (controladoria) e no departamento de contabilidade do IPEF.

Em função da legislação vigente, são arquivados pela empresa somente os valores pagos pela IPB ao IPEF nos últimos oito anos. Da mesma forma, o IPEF só dispõe desses valores para os últimos quatro anos. O registro do IPEF permitiu a classificação desses valores em:

a) projetos: valores relativos aos projetos firmados entre a International Paper do Brasil e o IPEF. Foram também atribuídos a esta classe todos os valores relacionados à execução dos projetos, tais como visitas, análise de dados, coleta de dados, outras análises etc;

b) treinamento: todos os valores associados à participação, por funcionários da empresa, de eventos no IPEF (treinamentos, cursos, palestras, congressos, simpósios etc.);

c) consultoria: valores destinados a pagamento de consultoria dos profissionais e professores do IPEF e que não estão no escopo de um projeto específico;

d) serviços: serviços prestados, tais como uso de laboratórios, análises, xerox etc;

e) sementes: valores pagos na compra de sementes e;

f) mensalidades: valores mensais relativos à manutenção do instituto.

Foram também levantados, na empresa, todos os valores investidos em pesquisa florestal nos últimos cinco anos. Esses valores permitiram o agrupamento em: 
a) salários e benefícios: gastos com pessoal, encargos, premiações, férias etc;

b) despesas gerais: despesas inerentes à administração do departamento de pesquisa, tais como manutenção, limpeza, material de escritório etc;

c) depreciação: investimentos na construção de laboratórios e salas, compra de carros, equipamentos etc;

d) treinamento: treinamento dos funcionários próprios.

\subsection{Cálculo do retorno financeiro sobre investimento em pesquisa}

Visando atender ao objetivo de se propor um método de avaliação do retorno aos investimentos em pesquisa florestal na IP, serão necessários os seguintes levantamentos:

a) Alocação dos investimentos na área de pesquisa cooperativa

Os valores totais investidos em pesquisa no Brasil são marcados pela sua abrangência nacional, ou seja, o Departamento de Pesquisa tem função coorporativa dentro da empresa, respondendo pelas atividades nos quatro estados em que ela atua. Nesse sentido, os investimentos são responsáveis pelo retorno não só na unidade do estudo de caso, mas em todas as áreas da empresa. Foram estabelecidas, pelos seus gerentes, prioridades para a alocação de tempos e recursos. Com base nesta tabela serão calculados proporcionalmente os valores investidos.

b) Cálculo do retorno

Para cálculo dos valores investidos foram utlizadas bases com as seguintes informações:

- valores estimados totais para investimentos em pesquisa, utilizando como base os valores estimados por projeto já descrito no item anterior;

- variação dos incrementos médios anuais, multiplicados pela rotação média da empresa (sete anos);

- preço da madeira, conforme levantamento já descrito; 
- receita total obtida por meio da multiplicação da variação da produtividade pela área plantável da empresa. (30.000 ha) e pelo preço da madeira representando a receita total do aumento da produtividade;

Receita $=(\Delta$ Produtividade $) \times 30.000$ ha $\times$ Preço da madeira

- Saldo, sendo a diferença entre a receita e os valores investidos;

Saldo $=($ Receita - Valores investidos $)$

- Valor Presente Líquido (VPL)

O VPL pode ser definido com a soma algébrica dos valores descontados do fluxo de caixa a ele associado. (REZENDE,2001)

$$
V P L=\sum_{j=0}^{N}(R j-C j)(1+i)^{-j}
$$

em que :

$\mathrm{Rj}=$ receita no final do ano $\mathrm{j}$;

$\mathrm{C} \mathrm{j}=$ custo no final do ano $\mathrm{j}$;

$\mathrm{i}=$ taxa de desconto;

$\mathrm{N}=$ duração do projeto.

- Taxa interna de retorno

Pode ser definida como a taxa anual de retorno do capital investido que iguala o valor atual das receitas futuras ao valor atual dos custos futuros do projeto. (Rezende,2001).

$$
\sum_{j=0}^{N}(R j-C j)(1+T I R)^{-j}=0
$$

em que :

$\mathrm{TIR}=$ taxa interna de retorno. 


\section{RESULTADOS E DISCUSSÕES}

Os resultados são apresentados em quatro partes: benefícios da pesquisa para a produtividade e qualidade, projetos apoiados pela integração universidade-empresa, valor do investimento em pesquisa e análise dos benefícios financeiros.

\subsection{Benefícios da pesquisa para a produtividade e qualidade}

Neste item, são apresentados os resultados obtidos por meio da análise dos dados coletados sob á ótica do aumento de produtividade e qualidade das florestas.

O aumento da produtividade florestal é resultado de uma série de fatores, dentre eles, o percentual de sobrevivência (Figura 7). A variação do percentual de sobrevivência das florestas pode estar ligada a alguns fatores:

a) problemas operacionais no plantio ou manutenção da floresta;

b) falta de qualidade das mudas provenientes do viveiro ou campo;

c) falta de adaptabilidade dos materiais genéticos; e,

d) fatores abióticos, como ventos, pragas, doenças e excesso ou falta de chuvas.

Além da redução do volume em função do menor número de árvores por hectare, outros problemas podem estar associados à mortalidade:

a) maiores problemas com matocompetição, em função do não fechamento das copas (incidência de sol) e, conseqüentemente, maior custo de manutenção das florestas; 
b) maior heterogeneidade de plantio, acarretando uma maior competição entre plantas. Estudos vêm sendo conduzidos dentro da empresa, associando a redução da produtividade com o aumento da heterogeneidade das florestas;

c) aumento da suscetibilidade a problemas de origem abiótica, como ventos ou pragas e doenças.

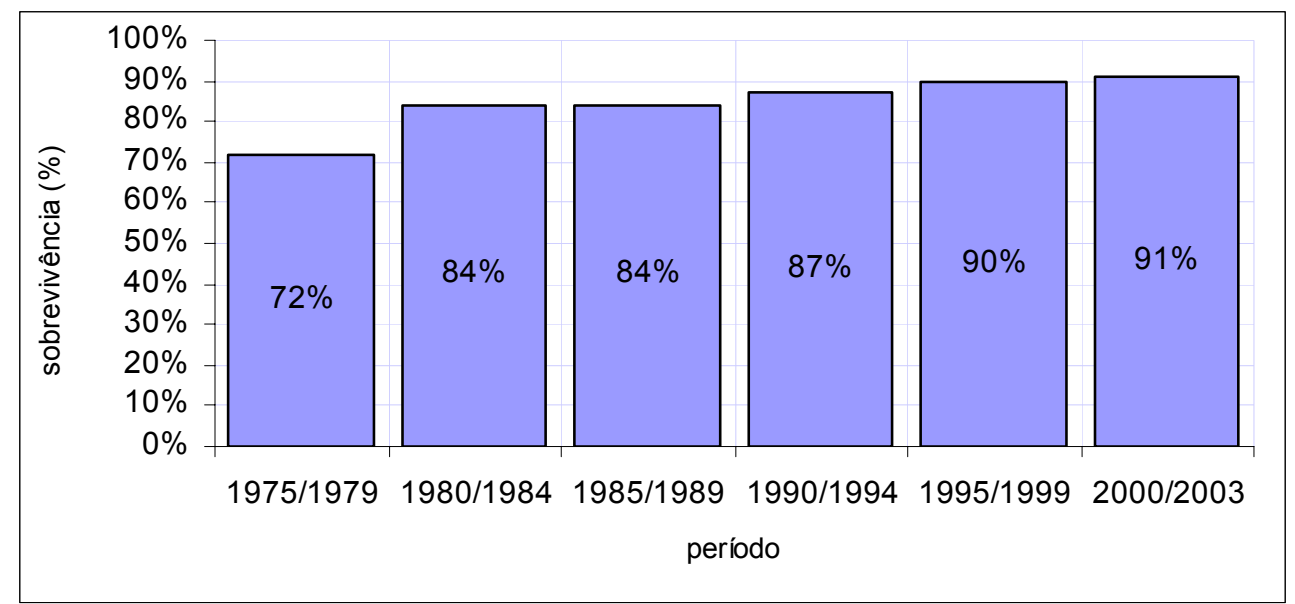

Figura 7 - Evolução da sobrevivência das florestas plantadas Fonte: Departamento de Planejamento e Inventário Florestal - IPB

Observou-se uma melhora em $26 \%$ se comparados os períodos de 1975/1979 a 1999/2003. A melhoria deste índice pode estar correlacionada a alguns fatores, tais como:

a) melhoramento: obtenção de materiais mais adaptados e a utilização de plantios clonais com clones recomendados baseado em característica de solo, relevo e clima (especificidade);

b) manejo: melhoria das práticas silviculturais empregadas e;

c) silvicultura: geração de cultura (tecnologia) de plantio ou no desenvolvimento de equipamentos e técnicas mais modernas, promovendo uma maior homogeneidade de plantio. 
Um dos impactos da melhoria na sobrevivência das florestas plantadas está representado na Figura 8, que diz respeito à evolução da produtividade (incremento médio anual) das florestas plantadas.

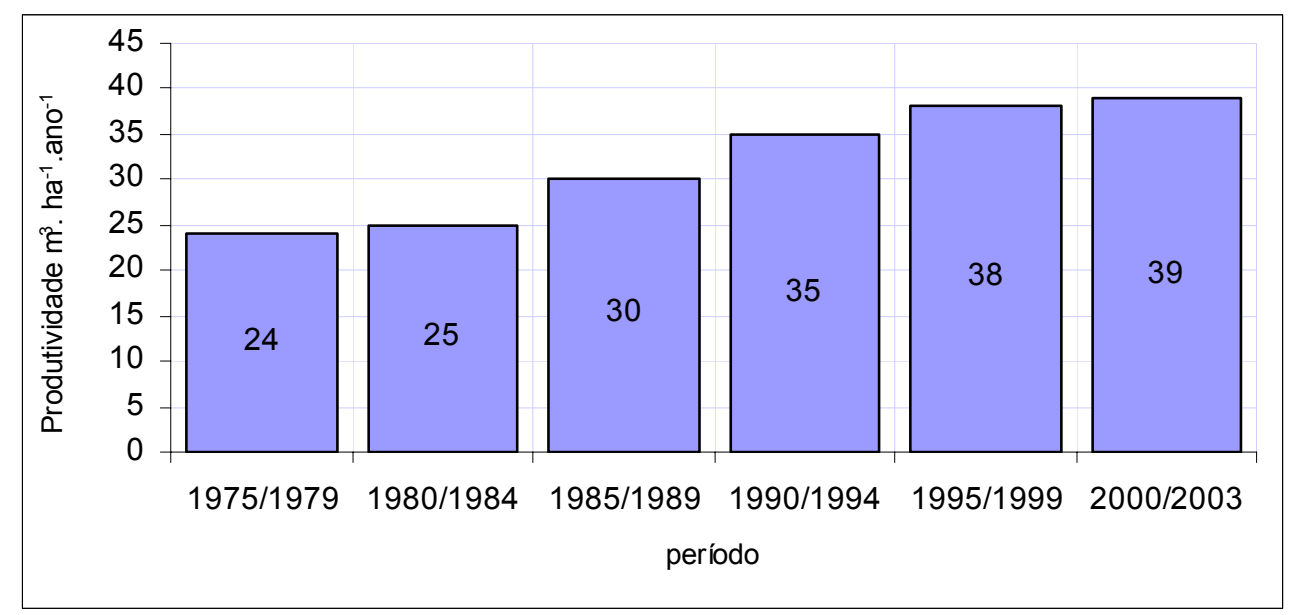

Figura 8 - Evolução da produtividade (incremento médio anual) para as florestas plantadas

Fonte: Departamento de Planejamento e Inventário Florestal - IPB

A evolução da produtividade pode também ser representada pela variação dos incrementos de produtividade, conforme Figura 9.

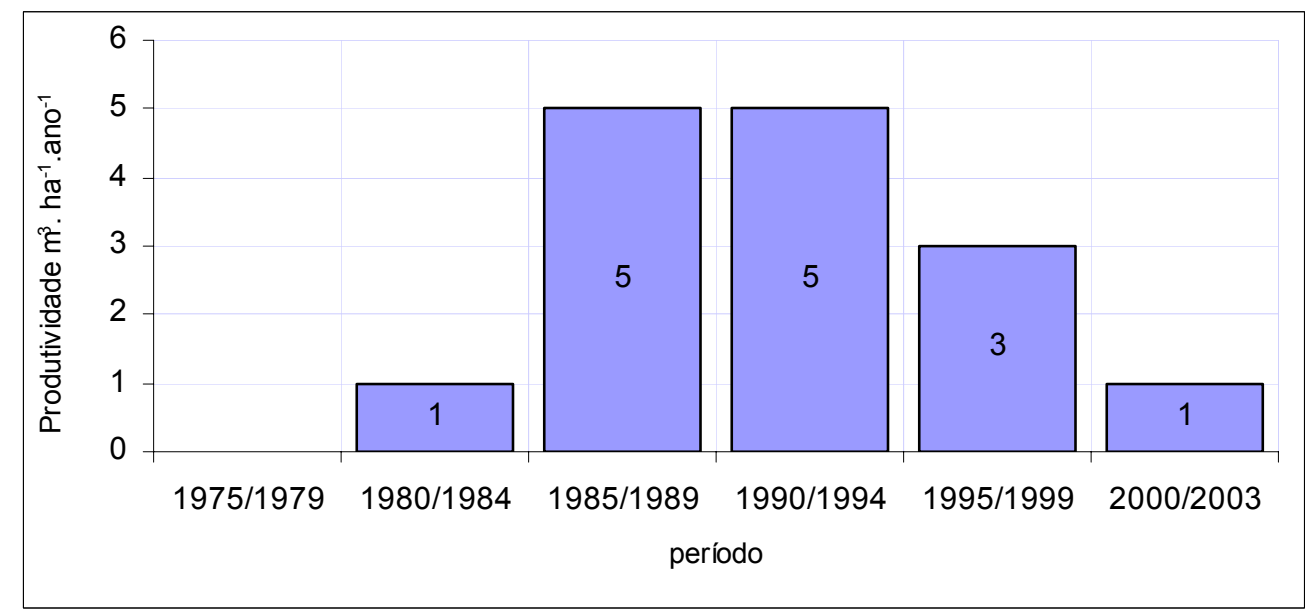

Figura 9 - Evolução dos aumentos do incremento médio anual das florestas plantadas 
Na Figura 9, observa-se, entre os anos de 1985/1999, variação mais expressiva, reduzindo para os outros períodos. Isto pode mostrar que os grandes ganhos de produtividade na área florestal já foram obtidos, fazendo com que os pesquisadores comecem a se interessar por temas que venham a garantir ganhos de qualidade na madeira e, principalmente, manutenção da produtividade atingida (sustentabilidade).

Uma prova dessas afirmações são os resultados das análises de rendimento em celulose das florestas da empresa (Figura 10).

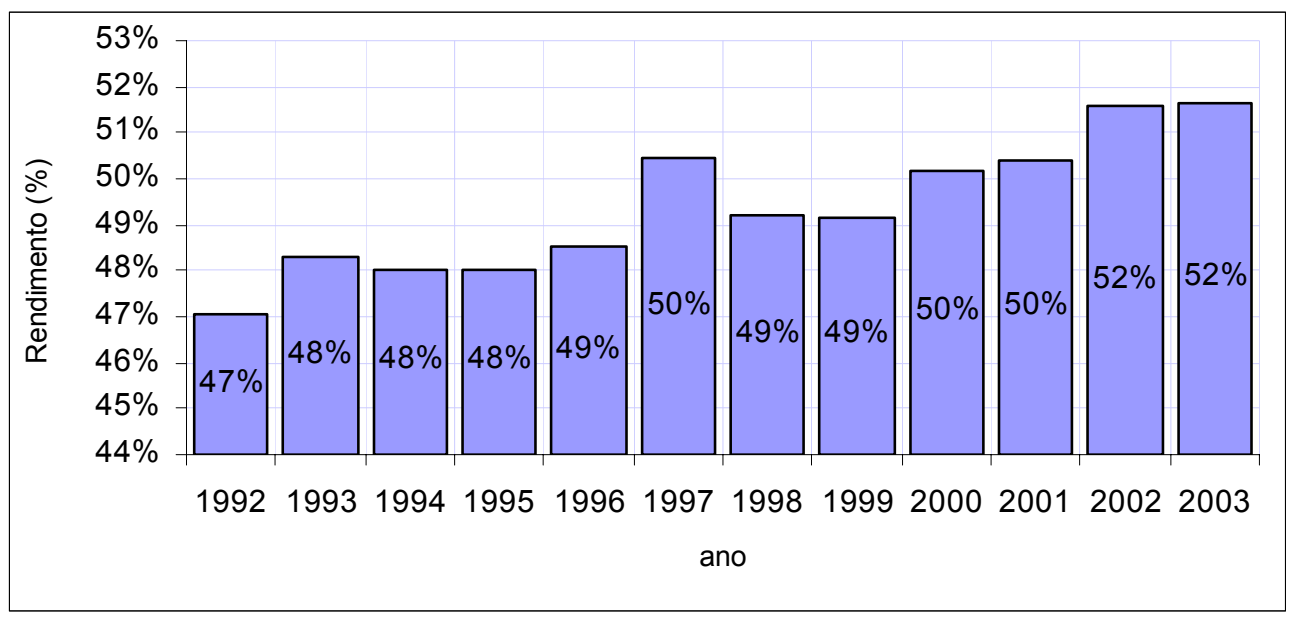

Figura 10 - Evolução do rendimento em celulose na madeira Fonte: Área fabril da IP

Os resultados mostrados na Figura 10 são marcados por um aumento considerável do rendimento da matéria-prima (madeira) na fábrica. Esses materiais, selecionados dentro do programa de melhoramento genético, possuem maior rendimento se comparado a materiais não melhorados.

Na Figura 11 é mostrada, ainda, a evolução do consumo específico dentro da fábrica. 


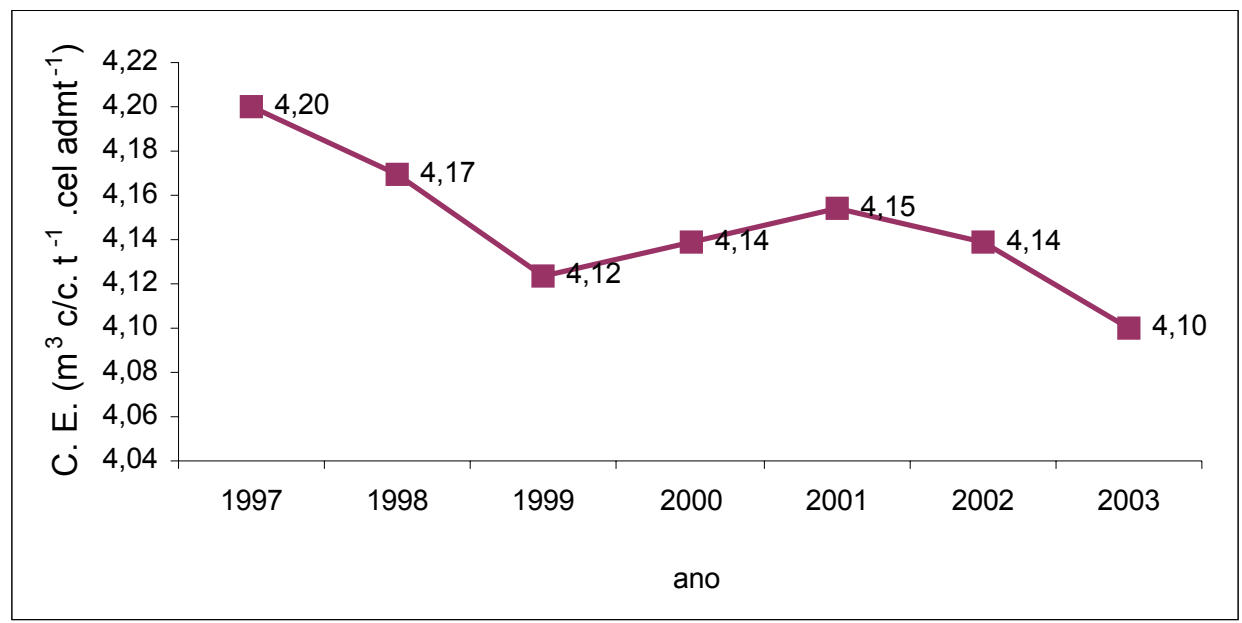

Figura 11 - Variação do consumo específico medido na fábrica Fonte: Área fabril da International Paper do Brasil

Apesar da base de dados não representar um período longo, observouse uma tendência de queda nos número de consumo específico.

Uma das causas desta melhoria observada na Figura 11, e representada pelo aumento da produtividade e da qualidade das florestas já mencionado neste capítulo, está ligada ao aumento da área plantada com materiais de origem clonal pela empresa (Figura 12).

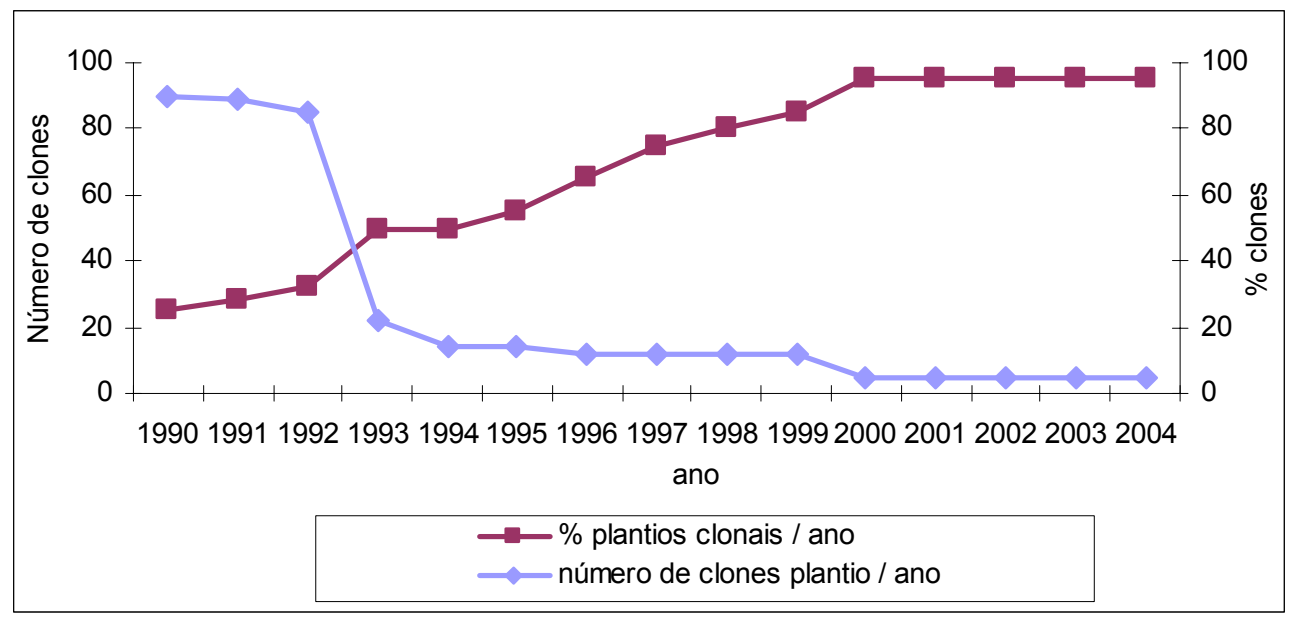

Figura 12 - Evolução do plantio clonal por ano x número de clones plantados por ano na IPB

Fonte: Comerio (1994) 
Na Figura 12 observa-se que a introdução dos materiais clonais começou no início dos anos 1990, utilizando-se aproximadamente $25 \%$ de clones dentro do programa de plantio comercial da empresa, evoluindo até atingir a estabilidade em torno de $95 \%$ da área plantada por ano. Observa-se também a estratégia da empresa na redução de número de clones plantados, passando de um total de 88 clones plantados por ano, em 1990 para cinco novos clones anuais nos últimos anos. Para alguns autores isto representa um risco controlado, pois, de um lado, têm-se materiais genéticos produtivos e com qualidade requerida ao processo; por outro lado, aumenta-se o risco de novas pragas, doenças ou outros fatores afetarem não só a produtividade, mas também a própria atividade florestal.

Um dos problemas na avaliação de projetos florestais pode ser notado na Figura 13, que mostra o percentual de clones abastecendo a fábrica e o grande período de tempo entre a realização da pesquisa e a sua recomendação para utilização final na fábrica. Observa-se que os primeiros materiais para a produção clonal foram selecionados em 1983, porém, o resultado só pôde ser observado na fábrica em 1997.

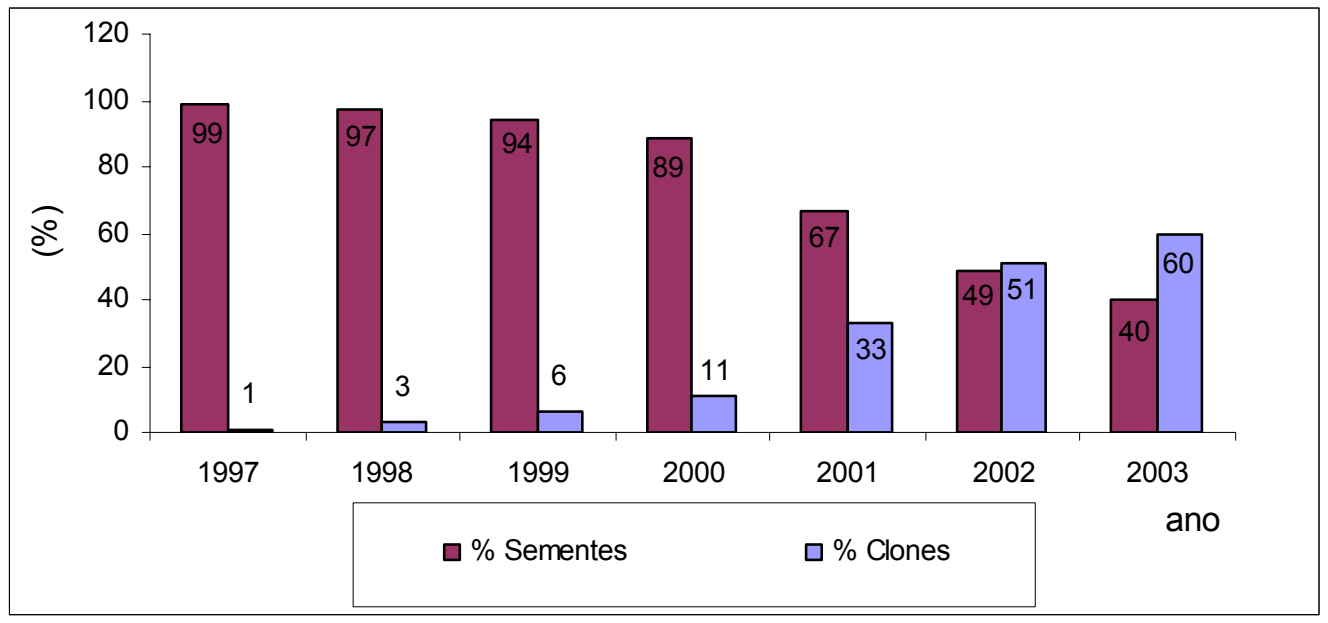

Figura 13 - Evolução da participação de madeiras de origem clonal na produção de celulose 
Na Figura 13 observa-se um aumento percentual de madeiras oriundas de florestas clonais. Entretanto, apenas em 2002 os percentuais de madeira de origem clonal ultrapassam o percentual de madeira oriunda de florestas de semente.

É interessante notar que o aumento da produtividade das florestas não foi suficiente para uma redução do custo da madeira para a IPB. Observa-se, de fato, um aumento no custo unitário dessa matéria-prima (Figura 14). Esse fato pode ser explicado pela composição final do abastecimento, que não é totalmente constituído por madeira proveniente de florestas próprias, existindo ainda uma dependência média, ao longo dos últimos anos, de 30\% do mercado. Nesse mercado, o preço do produto tem aumentado em termos reais.

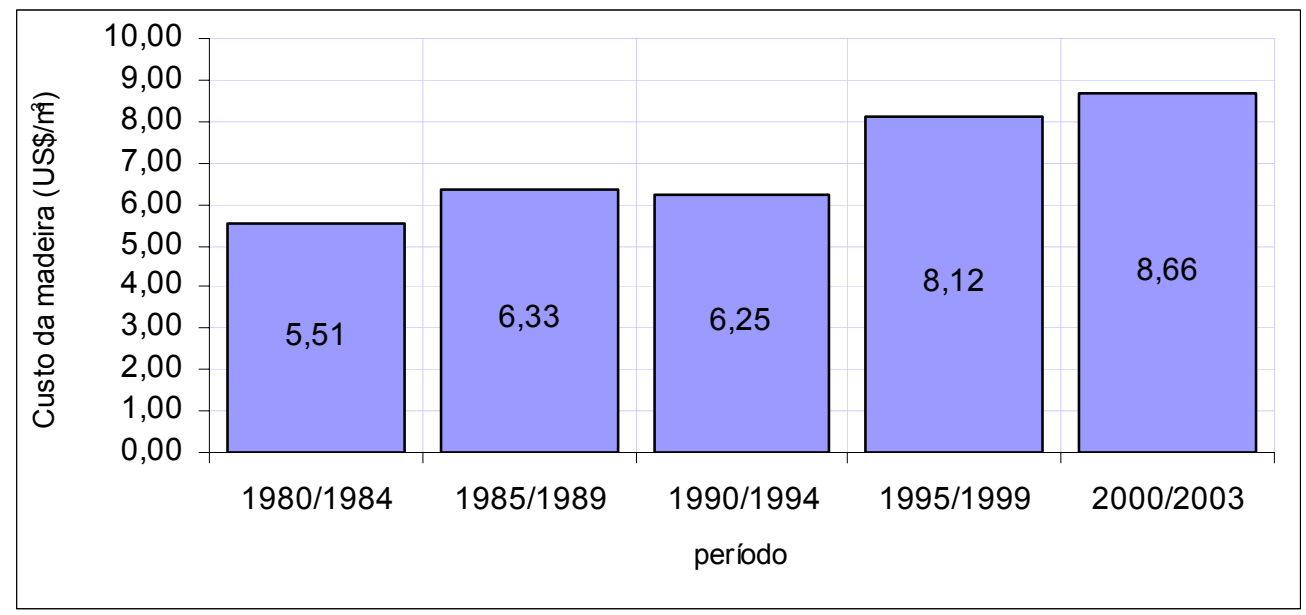

Figura 14 - Evolução dos preços de madeira em pé, US $\$ / \mathrm{m}^{3}$

Fonte: Departamento de Colheita IP

$\mathrm{O}$ aumento da produtividade e a qualidade da madeira afetaram $\mathrm{O}$ desempenho na fábrica e o rendimento por $\mathrm{m}^{3}$ de madeira consumida. $\mathrm{Na}$ Figura 15 está representada a evolução da produção de celulose na fábrica. 


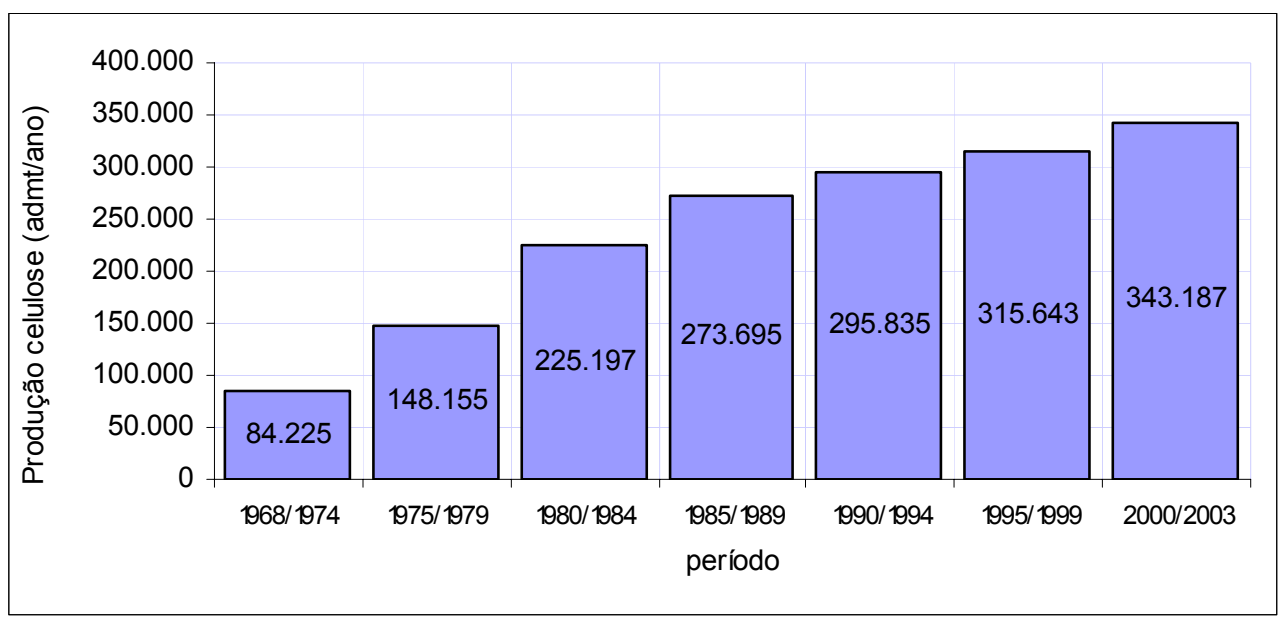

Figura 15 - Evolução da produção celulose admt/ano, para a fábrica da International Paper em Mogi Guaçú

Pela Figura 15, observa-se uma grande evolução da produção da fábrica, principalmente nos períodos de 1975/1979 e 1980/1984, devido, principalmente, aos investimentos em equipamentos (digestores e caldeiras). Com esses equipamentos, a fábrica, a partir de 1985, estabilizou sua capacidade de produção, passando a ter apenas ganhos de produtividade devido a pequenas mudanças no processo de fabricação.

Com base nas informações geradas e apresentadas, pode-se calcular, como forma de diagnosticar os benefícios do aumento da produtividade, os seguintes índices/valores:

a) Necessidade de área plantada em função do aumento da produtividade:

Pode-se estimar, em função da melhoria na taxa de conversão madeiracelulose, o impacto sobre a área total necessária para abastecer a fábrica (Figura 16). 


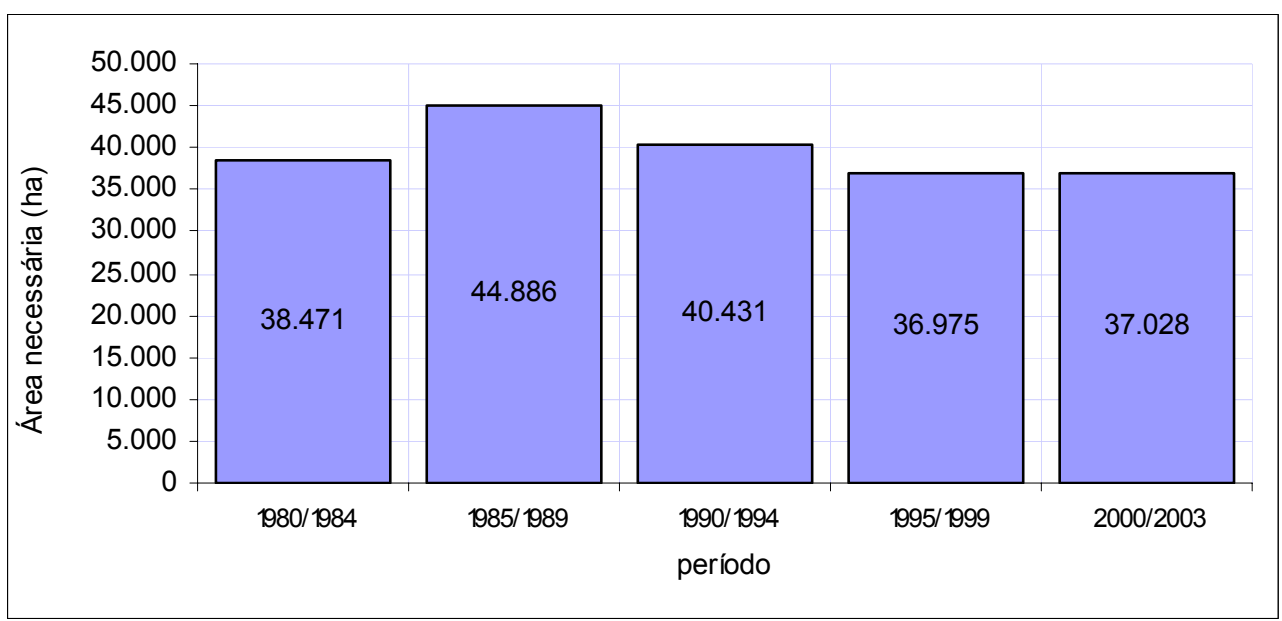

Figura 16 - Variação na área necessária para abastecimento da fábrica em função da melhoria da qualidade da madeira

Os dados da Figura 16 mostram que seriam necessários, no período 1980/1984, 38.471 ha para abastecer a fábrica com 100\% da necessidade de celulose. Porém, este valor representa um período com baixa produção de celulose. Quando observados os períodos em que a produção de celulose foi mais constante (1990 em diante) e, apesar de existirem pequenos aumentos de consumo, não considerados nesta análise, observou-se que o aumento da produtividade proporcionou uma redução da área necessária para abastecer a fábrica.

Pode-se, então, calcular financeiramente o impacto que uma redução de produtividade pode causar, por meio de:

- não aquisição de novas áreas, sujeitas ao valor da terra na localidade e percentual de aproveitamento de plantio. As aquisições de novas áreas representam aumentos nos ativos da empresa e, conseqüentemente, reduções nos índices de rentabilidade;

- redução de impactos ambientais, uma vez que a utilização das áreas é menor; 
b) percentual de auto-suficiência no abastecimento de madeira: a empresa manteve historicamente um percentual de abastecimento de madeira proveniente de três fontes:

- própria: oriunda de áreas próprias da empresa;

- parceria/fomento: plantios em áreas arrendadas, em que o pagamento pelo arrendamento é feito indexado ao valor da madeira e;

- mercado: compra de madeira no mercado.

Para a produção de 1 (uma) tonelada de celulose admt são necessários, em média, $4,2 \mathrm{~m}^{3} \mathrm{c} / \mathrm{c}$ (consumo específico), isto representa que, para produzir 350.000 admt ano, são necessários $1.470 .000 \mathrm{~m}^{3}$ de madeira. Considerandose que os dados de produtividade refletem a data de plantio das florestas e não sua entrada na fábrica, pode-se assumir que a produtividade de um período ( 5 anos) irá refletir no consumo do próximo período. Considerando ainda que a empresa dispõe de 30.000 de florestas para efetivo plantio, apresentam-se as estimativas de percentuais de abastecimento próprio da empresa (Figura 17).

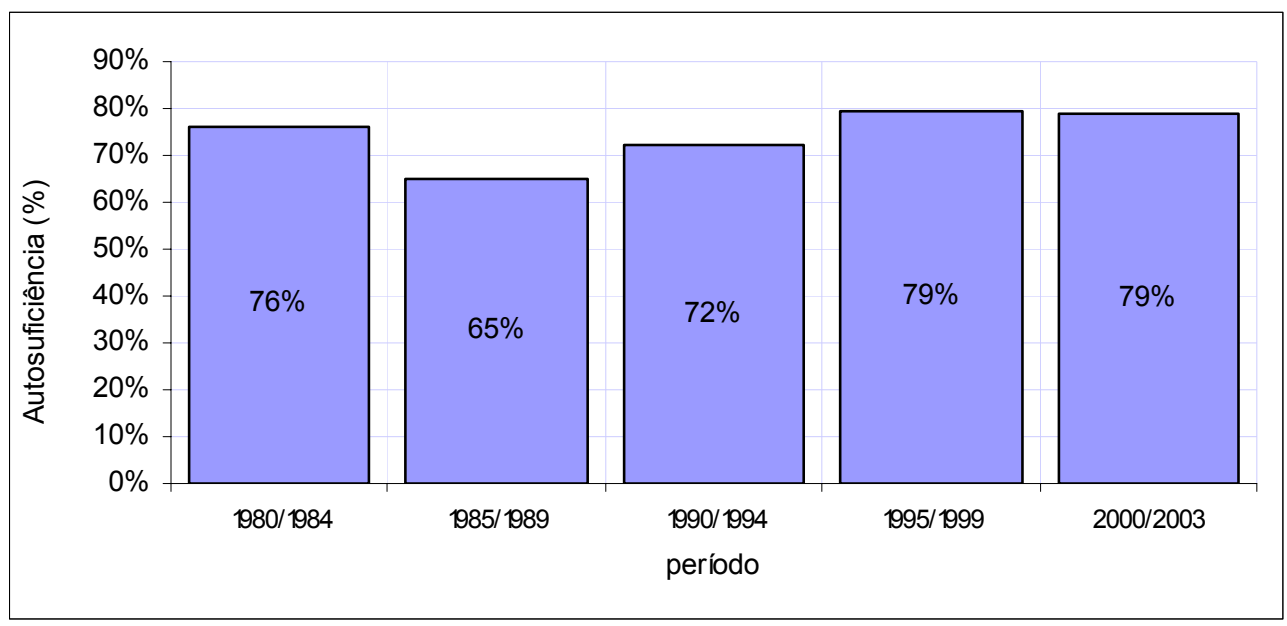

Figura 17 - Estimativa de auto-suficiência em função da produtividade e da produção de celulose

Observa-se, na Figura 17, que no período de 1980/1984, em função da baixa produção de celulose (Figura 15) e, conseqüentemente, baixo consumo 
de madeira, o impacto no abastecimento é menor, mesmo considerando produtividade na ordem de $24 \mathrm{~m}^{3} / \mathrm{ha}$ /ano. Porém, quando analisam-se os outros períodos, nota-se que a necessidade de madeira de outras fontes (parcerias, fomento e mercado) é menor. Isto pode representar uma redução do custo na produção de celulose, uma vez que as madeiras de outras fontes são notadamente mais caras e com qualidade inferior às produzidas pela empresa nas áreas próprias.

\subsection{Projetos apoiados pela integração universidade-empresa}

O modelo de integração universidade-empresa usado pela IP, no âmbito do convênio USP-IPEF, no desenvolvimento do seu programa de pesquisa florestal, resultou no desenvolvimento de 203 projetos durante o período de 1965 a 2004. Os dados são apresentados em função da sua distribuição dentro dos grupos temáticos básicos e do período de tempo (Figura 18 e 19).

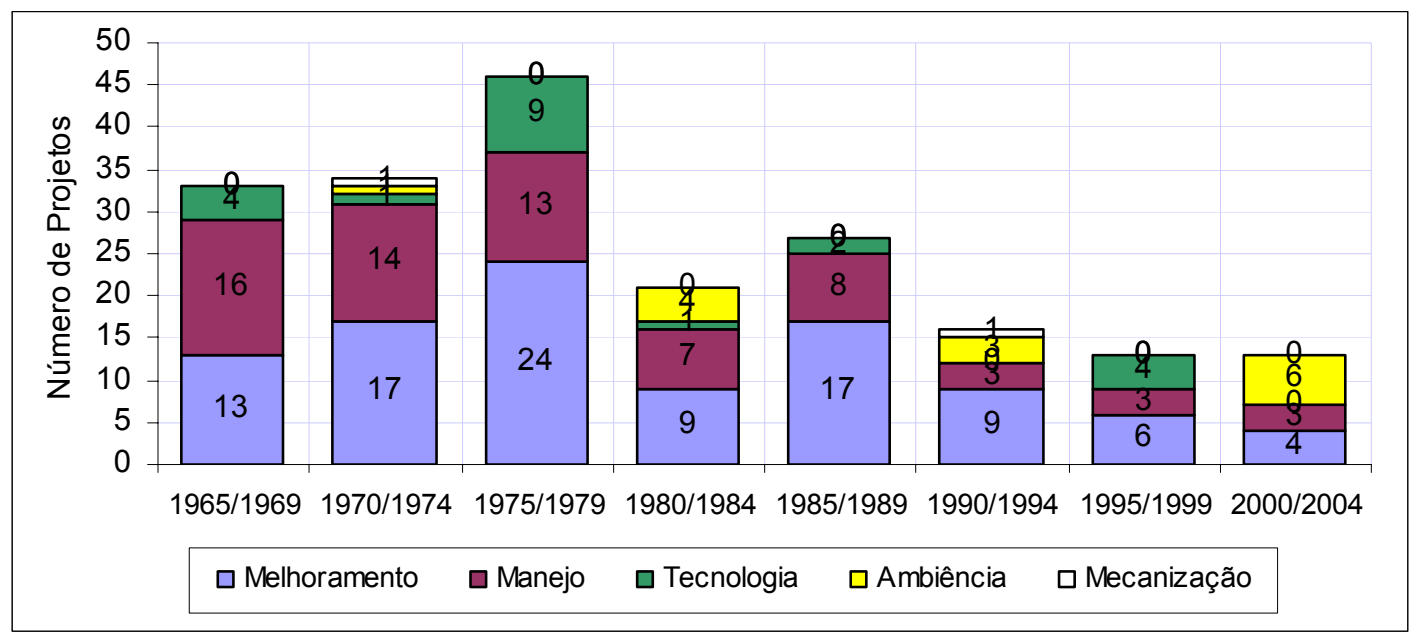

Figura 18 - Levantamento dos projetos do IPEF, em parceria com a IPB, em função dos grupos e períodos 


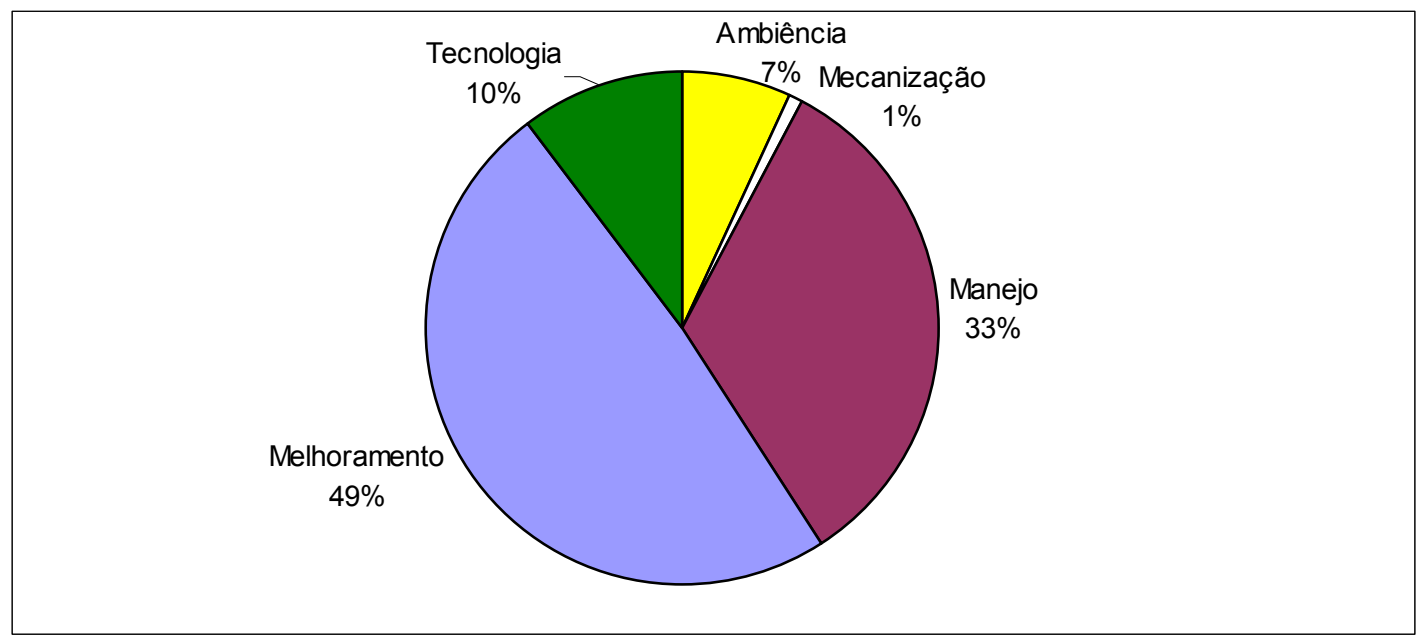

Figura 19 - Participação percentual dos grupos dos projetos do IPEF em parceria com a IPB

Com base nas Figuras 18 e 19, é possível afirmar que:

a) houve uma grande redução no número de projetos nos últimos anos, sendo a média dos últimos 10 anos de 2,6 projetos/ano;

b) as áreas mais pesquisadas foram as de melhoramento, com $49 \%$ do total de projetos e a de manejo, com $33 \%$ do total de projetos, seguidas das áreas de tecnologia (10\%), ambiência (7\%) e colheita/mecanização (1\%);

c) nas décadas de 1960 e 70 ocorreu quase que uma predominância dos temas de melhoramento (seleção de árvores para produção de sementes, introdução de novas espécies/procedências) e manejo (adubação e espaçamento). Essas áreas representavam 101 projetos de um total de 113, (89\% do total). Foi nesse período também que teve início a inclusão de variáveis de qualidade da madeira (principalmente densidade) em programas de melhoramento;

d) nas décadas de 1960 e 70, a ênfase em trabalhos na área de ambiência é pequena, só passando receber mais atenção na década de 1980, como requisito para a obtenção de certificações de órgãos ambientais e organismos certificadores como a ISO; 
e) poucos trabalhos foram desenvolvidos na área de mecanização, acredita-se, em função da empresa manter pessoal qualificado para estudar e implementar os programas de mecanização;

f) a partir da década de 1980, três fatos marcaram a redução do número de projetos: o desenvolvimento de áreas de pesquisa internamente, a redução dos investimentos em função do fim dos incentivos fiscais e a estratégia do IPEF de atuar mais efetivamente em programas cooperativos e temáticos;

g) a partir de 1990 houve uma estabilização no número de projetos realizados;

h) existe demanda por trabalhos nas áreas de qualidade de madeira, visto o pouco conhecimento da relação entre fatores genéticos e variáveis ambientais das variáveis de interesse, e de genômica, tais como trangênicos, marcadores moleculares e embriogênie somática.

Numa análise mais profunda, e utilizando o levantamento por subgrupos, observa-se uma grande predominância de dois temas principais: adubação e melhoramento clássico. Estes temas, somados, representam $34 \%$ de todos os projetos realizados pelo IPEF (Figuras 20 e 21).

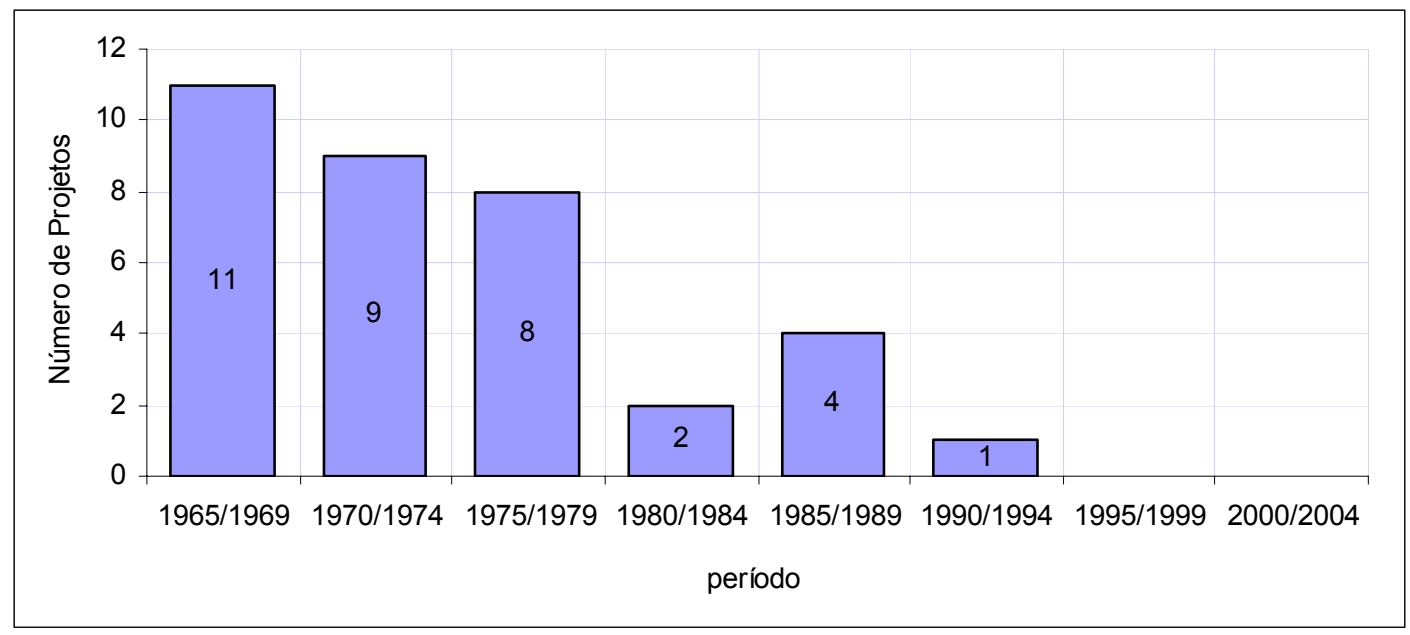

Figura 20 - Temas do subgrupo adubação

O subtema Adubação foi encontrado 34 vezes (Figura 20), representando $17 \%$ dos temas estudados. Se for analisado apenas o período 
de 1965 a 1969, o tema é encontrado 11 vezes, ou 33\% dos projetos efetuados. Isto demonstra a grande preocupação da época com o tema e a mudança na preocupação do mesmo nos anos seguintes, tendo muitos trabalhos nessa área migrado para o desenvolvimento interno de pesquisa.

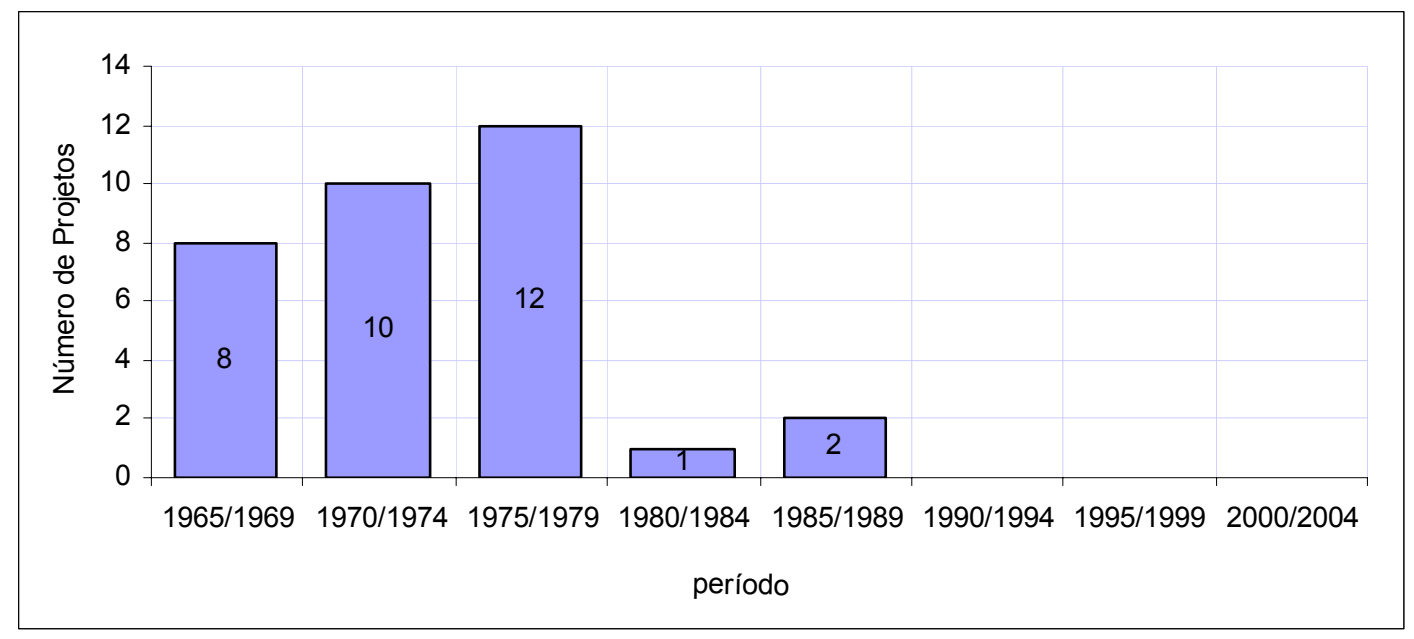

Figura 21 - Temas do subgrupo melhoramento

A mesma constatação é feita sobre o subtema Melhoramento (Figura 21), destacando-se o grande número de projetos no período de 1975 a 1979 (26\% dos projetos totais). Isto pode ser explicado pela grande quantidade de introdução de novos materiais de E. urophylla e E. grandis. O número cai sensivelmente nos próximos períodos, em função da estratégia da empresa de selecionar indivíduos dentro dessas populações para o programa de clonagem e hibridação, reduzindo-se a introdução de novos materiais. Porém, observouse uma carência de pesquisa nesta área do conhecimento florestal, preocupação essa também observada pela empresa, tendo este tema ocupando lugar de destaque dentro do plano diretor de pesquisas da empresa.

Além da análise quantitativa dos projetos, propõe-se uma avaliação de adoção das tecnologias geradas pelos trabalhos realizados. Por ser uma variável de caráter subjetivo, ela deve ser analisada com o devido 
conhecimento dos fatos e sua origem (pesquisa). Apresenta-se a aplicabilidade dos projetos de quatro formas:

- aplicabilidade dos projetos por período (Figura 22);

- aplicabilidade total dos projetos (Figura 23);

- aplicabilidade dos projetos por área (Figura 24);

- aplicabilidade dos projetos por subáreas (Figura 25).

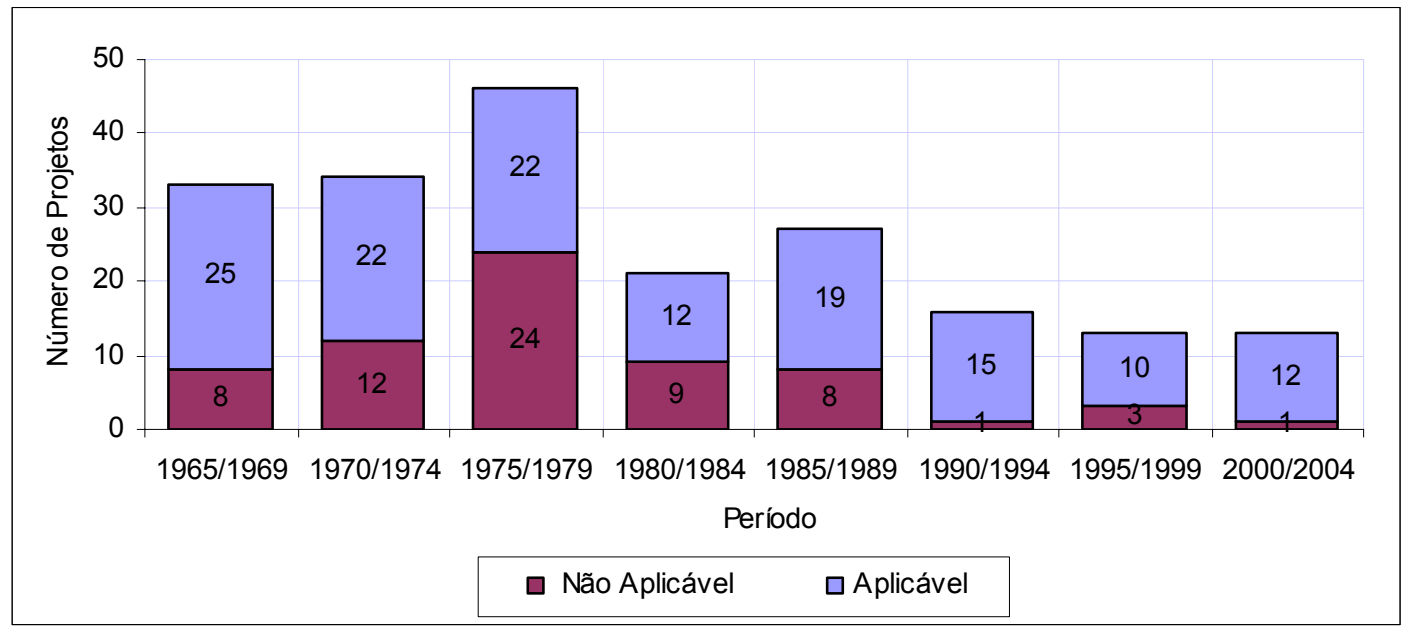

Figura 22 - Aplicabilidade dos projetos por período

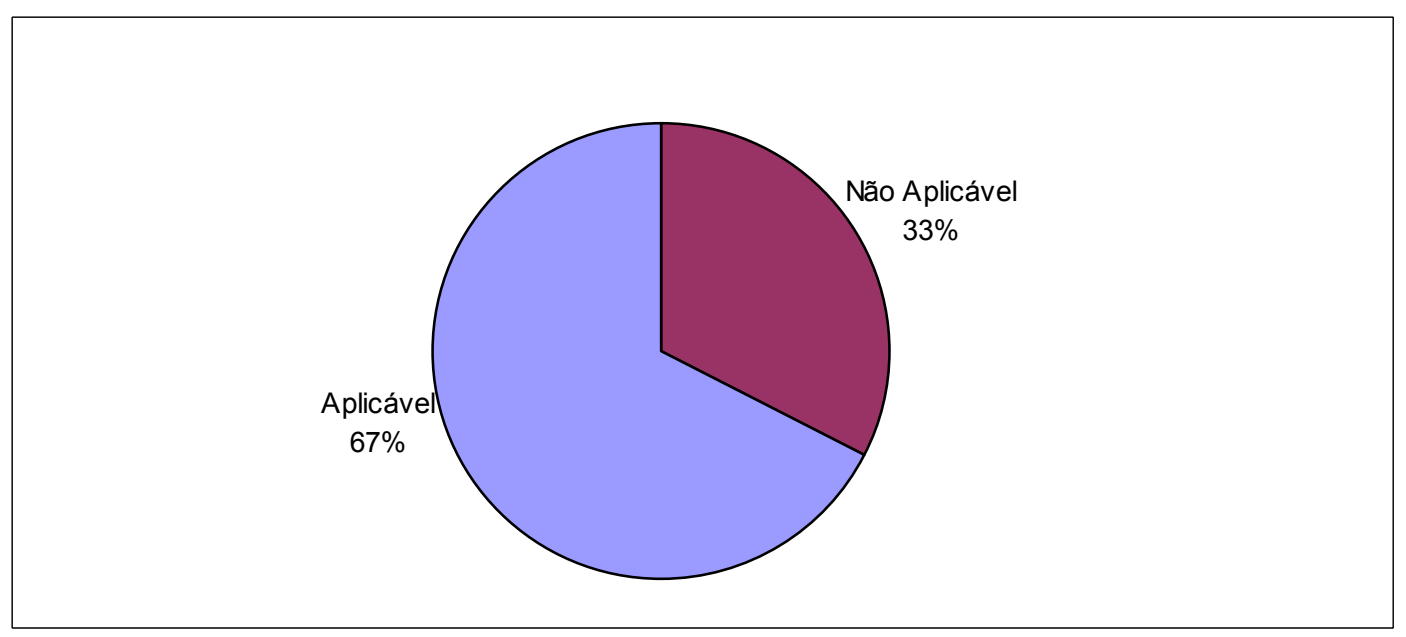

Figura 23 - Aplicabilidade total dos projetos 


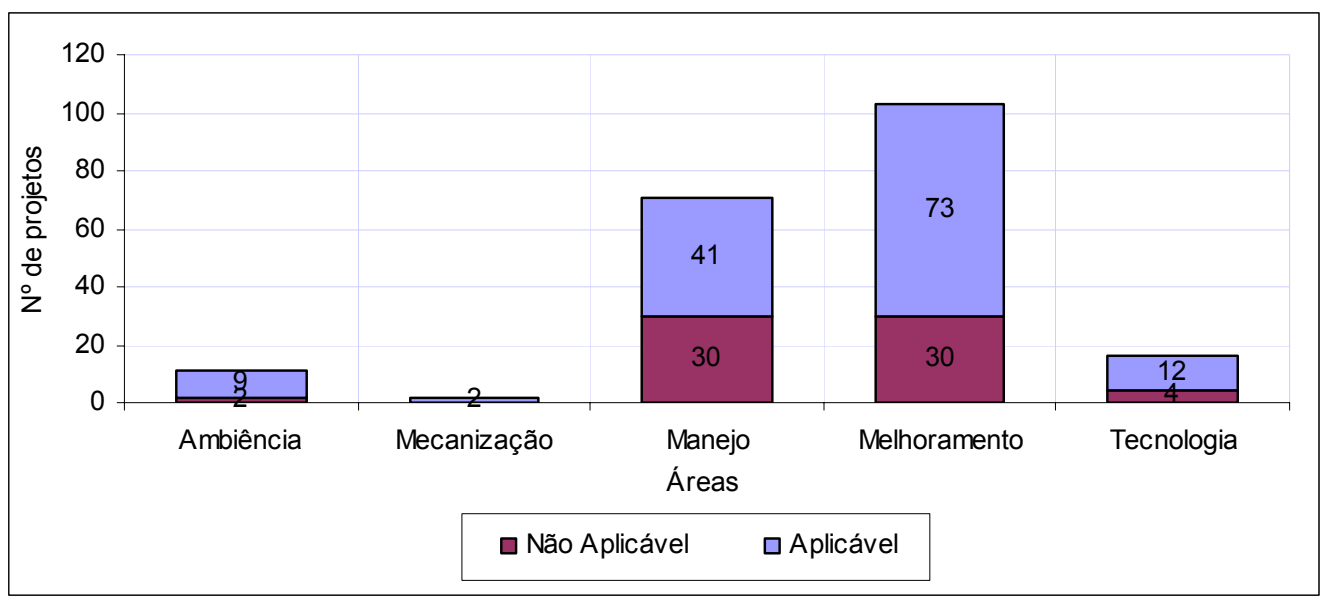

Figura 24 - Aplicabilidade dos projetos por área

Com base nas Figuras 22, 23 e 24, pode-se afirmar que:

a) $67 \%$ dos projetos foram classificados como aplicáveis, entretanto, um número bastante alto de projetos (33\%) poderiam ser evitados ou conduzidos de outra forma;

b) no período de $1975 / 1979,52 \%$ dos projetos foram classificados como não aplicáveis, sendo o ponto em que esta variável atingiu seu valor mais alto coincidindo com o momento de reestruturação e redefinição das estratégias de pesquisa do Instituto;

c) nos últimos anos, os percentuais de não aplicabilidade vêm diminuindo. Isso demonstra uma preocupação na elaboração de demandas para os associados, como o relatório com a pesquisa de demandas preparada pelo IPEF junto às associadas no ano de 2002, visando definir as principais linhas de atuação do Instituto;

d) o índice de aplicabilidade pode representar o índice de adoção de novas tecnologias, tendo o resultado apresentado mostra altos índices de eficiência das pesquisas realizadas;

e) os responsáveis pela pesquisa na empresa, ao responderem os questionários de aplicabilidade, podem ter encontrado dificuldades devido: 
- às mudanças nos objetivos, se comparados com os inicialmente propostos;

- à definição incorreta de objetivos no início do projeto, se consideradas as questões e os problemas que deveriam estar sendo priorizados.

Vale lembrar que o levantamento realizado indica que os resultados podem ser obtidos a partir de um produto ou conhecimento gerado, não tendo necessariamente o objetivo de verificar a utilização dos resultados das pesquisas. Problemas de percepção podem ter ocorrido, principalmente em áreas onde os resultados não são claramente observados ou medidos, como nas áreas de ambiência e manejo com temas voltados para a manutenção da produtividade e sustentabilidade.

O gráfico da Figura 25 analisa os dados gerados pelos questionários de aplicabilidade em subáreas.

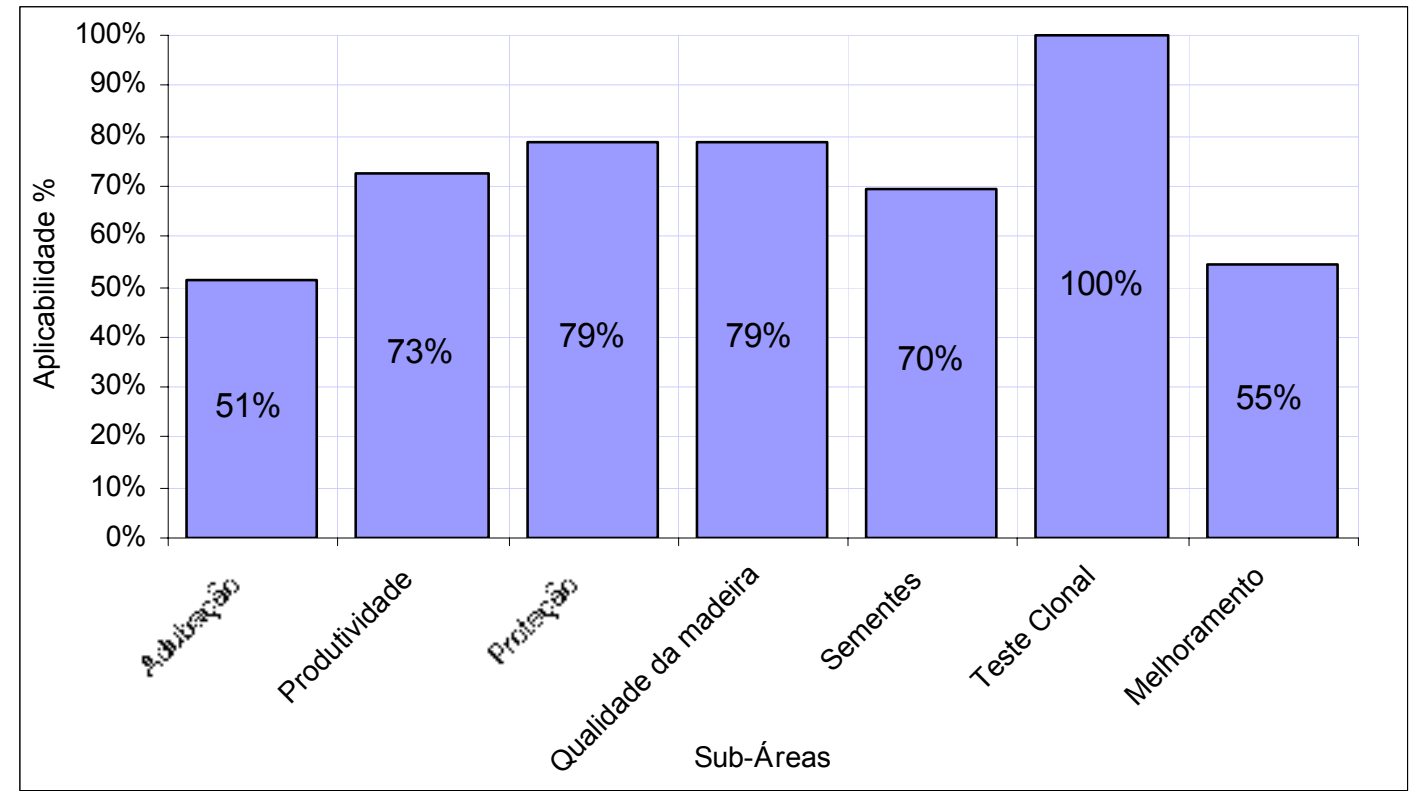

Figura 25 - Aplicabilidade dos projetos por subáreas

Deve-se considerar, na Figura 25, o número de projetos por subáreas. Nota-se, para as subáreas mais estudadas (adubação e melhoramento, Figuras 
20 e 21), um baixo percentual de aplicabilidade (51\% e 55\%, respectivamente). Isso pode significar que existiram muitas tentativas (sem sucesso) de estudos para tecnologias alternativas ou que existe uma necessidade da revisão dos objetivos e produtos das pesquisas efetuadas nestas áreas específicas.

\subsection{Valor do investimento em pesquisa}

Na Tabela 11 está representado o resultado dos levantamentos dos valores investidos no IPEF, entre os anos de 1996/2003.

Tabela 11. Levantamento dos valores investidos em pesquisa no IPEF entre os anos de 1996 a 2003

\begin{tabular}{ccc}
\cline { 2 - 3 } Ano & US\$ \\
\cline { 2 - 3 } 1996 & 34.231 \\
1997 & 33.885 \\
1998 & 31.875 \\
1999 & 26.882 \\
2000 & 27.433 \\
2001 & 33.218 \\
2002 & 50.787 \\
2003 & 55.432 \\
Total & 293.742
\end{tabular}

Fonte : Controladoria IP e Departamento fiscal IPEF

Agrupando-se esses valores novamente, são obtidos os resultados da Tabela 12. 
Tabela 12. Levantamento dos valores investidos médios (US\$) de 1996 a 2003 por período

\begin{tabular}{ccc}
\hline Ano & US\$ & CV \\
\hline $1996 / 1999$ & 31.718 & $9 \%$ \\
$2000 / 2003$ & 41.717 & $28 \%$ \\
\hline Média & $\mathbf{3 6 . 7 1 8}$ & $\mathbf{2 7 \%}$
\end{tabular}

Os valores apresentados na Tabela 12 representam a média aritmética por ano. O coeficiente de variação para cada classe é também apresentado.

Notou-se um considerável aumento dos valores de 1996/1999 para $2000 / 2003$. Porém, o coeficiente de variação do período de 2000/2003 indica uma grande diferença entre os valores dentro da classe.

Analisando-se os valores classificados pelo destino dos recursos, têm-se os dados apresentados na Tabela 13.

Tabela 13. Composição dos valores investidos no IPEF (US\$), de 1999 a 2003

\begin{tabular}{cccccccc}
\hline Ano & Projetos & Treinamento & Consultoria & Serviços & Sementes & Mensalidade & Total geral \\
\hline $\mathbf{2 0 0 0}$ & 1.530 & 3.645 & 2.890 & 6.252 & 1.313 & 11.803 & 27.433 \\
$\mathbf{2 0 0 1}$ & 5.348 & 3.064 & 2.794 & 8.718 & 4.103 & 9.191 & 33.218 \\
$\mathbf{2 0 0 2}$ & 25.091 & 485 & 1.484 & 13.081 & 3.249 & 7.397 & 50.787 \\
$\mathbf{2 0 0 3}$ & 43.287 & 1.781 & 1.298 & 1.602 & 451 & 7.013 & 55.432 \\
\hline Total & $\mathbf{7 5 . 2 5 6}$ & $\mathbf{8 . 9 7 4}$ & $\mathbf{8 . 4 6 6}$ & $\mathbf{2 9 . 6 5 3}$ & $\mathbf{9 . 1 1 6}$ & $\mathbf{3 5 . 4 0 5}$ & $\mathbf{1 6 6 . 8 7 0}$
\end{tabular}

Fonte: Departamento Fiscal IPEF 
Analisando-se os valores na forma gráfica, por percentuais, apresenta-se a Figura 26.

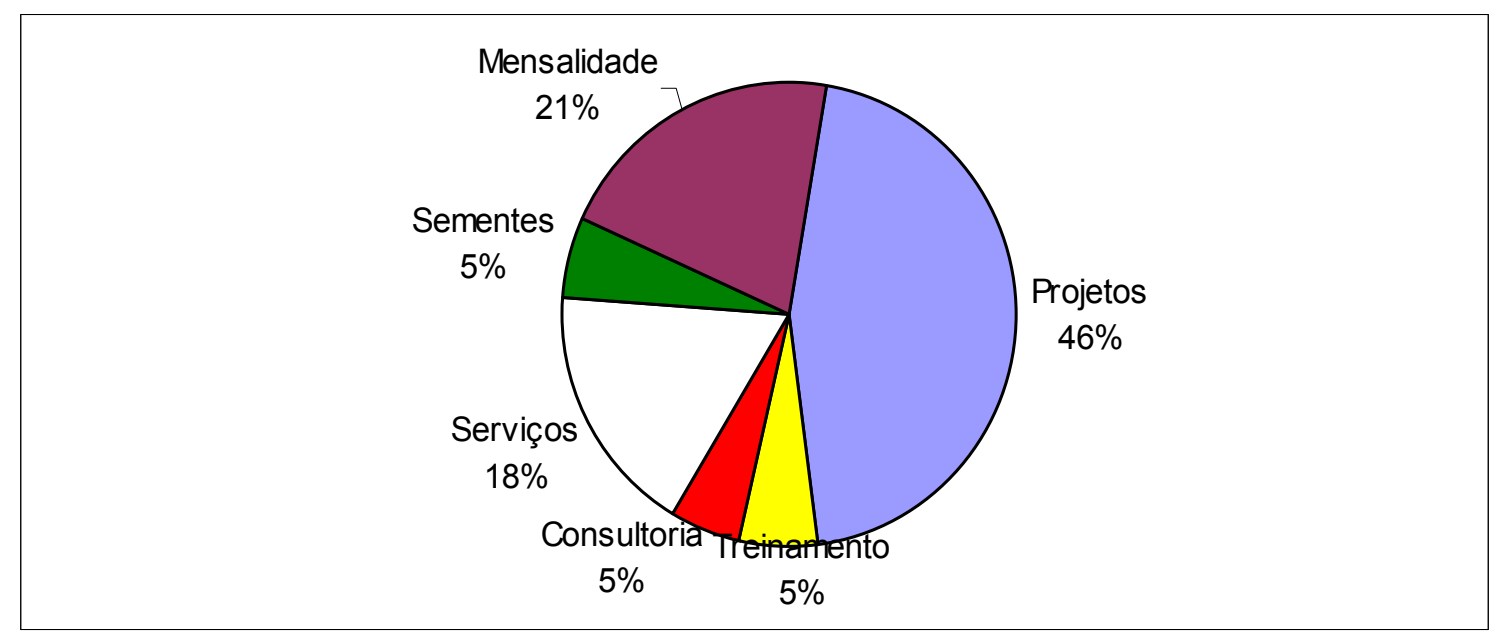

Figura 26 - Composição percentual dos valores investidos de 2000 a 2003 Fonte: Departamento fiscal IPEF

Analisando-se a Figura 26, pode-se afirmar que:

a) $18 \%$ dos valores foram destinados à obtenção de serviços, mostrando a importância dos laboratórios do IPEF na prestação de serviço de apoio às empresas associadas. Esses serviços são basicamente para o atendimento de pesquisas e necessidades desenvolvidas internamente nas associadas, uma vez que serviços associados a projetos do IPEF estão classificados como projetos;

b) no percentual relativo a sementes florestais, observou-se que a quase totalidade desse valor é representada pelas sementes de nativas, tendo as sementes de exóticas para reflorestamento (principalmente do gênero Eucalyptus) sido importantes apenas no começo do programa de melhoramento das empresas;

c) os números referentes a treinamento (transferência de tecnologia, extensão) representam apenas $7 \%$ do total investido e; 
d) o valor correspondente a mensalidades corresponde a $21 \%$ do total investido no IPEF, porém, houve uma redução percentual na participação dessa classe nos últimos anos (Figura 27).

A Figura 27 representa a movimentação, nos últimos cinco anos, dos percentuais destinados às diferentes classes de valores.

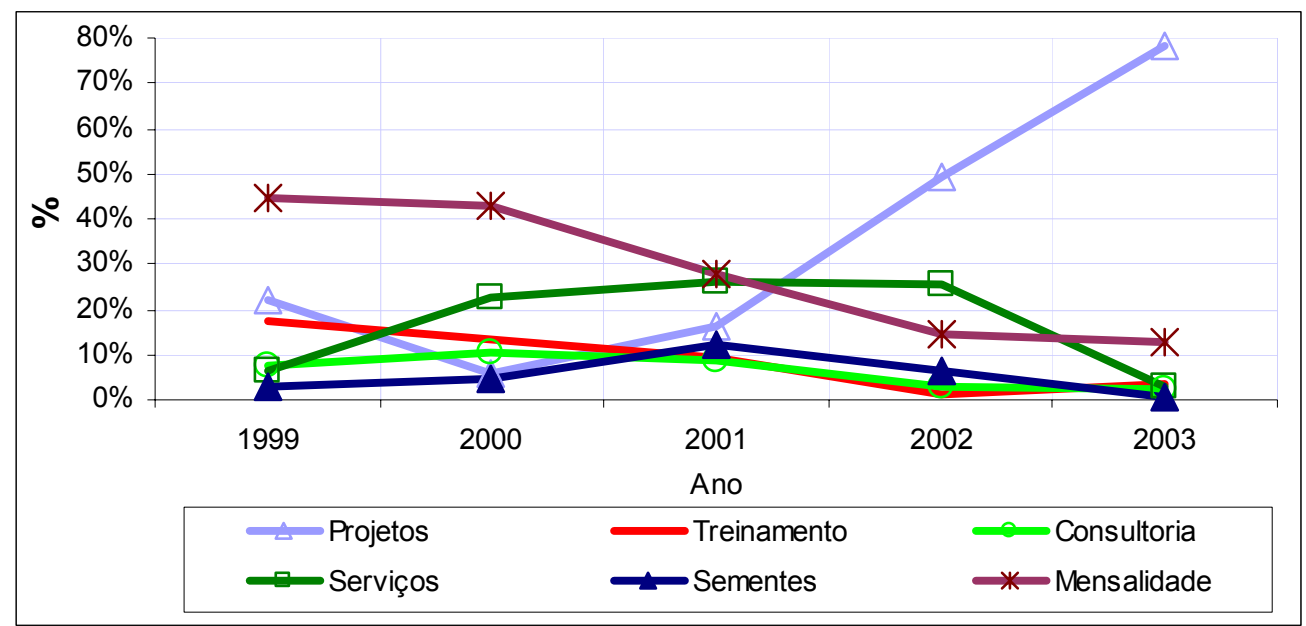

Figura 27 - Composição dos valores investidos no IPEF, de 1999 a 2003

Como mencionado no parágrafo anterior, a participação do item mensalidades, representa, hoje, $12 \%$ do total investido.

Verificou-se um aumento expressivo da participação percentual do item projetos. Isso pode ser explicado não pelo aumento do número de projetos, mas pelo aumento do custo por projeto. Este valor pode ser obtido dividindo-se o valor correspondente ao item projetos pelo número de projetos realizados por ano. Os resultados encontram-se na Figura 28. 


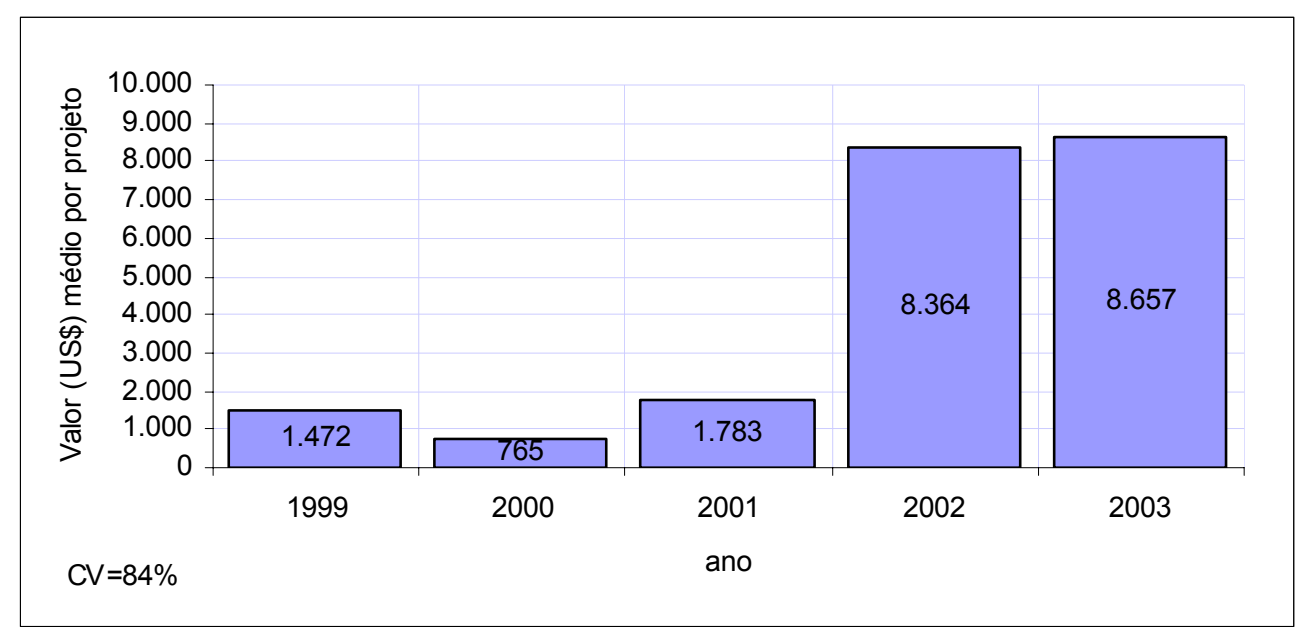

Figura 28 - Valor médio por projeto

Na Figura 28, nota-se que, a partir de 2002, os valores médios por projetos aumentaram 370\% (2001 para 2002), sendo possível afirmar que:

a) os novos desafios apresentados encontram-se em áreas até então pouco estudadas, como os projetos nas áreas de genômica e modelos ecofisiológicos, cujos investimentos são maiores e os retornos até então ainda não são comprovados, porém, estudos preliminares indicam alto potencial de desenvolvimento;

b) as empresas vêm buscando no IPEF apenas projetos que não são viáveis dentro da empresa, seja pela falta de conhecimento específico, seja pelos valores dos investimentos em laboratórios e análises.

Procurou-se, ainda, neste trabalho, em função da pouca quantidade de dados disponíveis, criar uma metodologia para estimar os valores investidos para todos os períodos da existência do convênio entre a International Paper do Brasil e o IPEF. A Tabela 14 apresenta os dados levantados. 
Tabela 14. Valores bases para estimativa dos investimentos realizados

\begin{tabular}{|c|c|c|c|c|c|c|c|c|c|c|c|}
\hline $\begin{array}{c}\text { Experimento } \\
\text { Área }\end{array}$ & Subárea & $\begin{array}{l}\mathrm{N}^{\circ} \\
\text { anos }\end{array}$ & $\begin{array}{c}\mathbf{N}^{\circ} \\
\text { medições }\end{array}$ & $\begin{array}{c}\mathrm{n}^{\circ} \\
\text { diárias } \\
\text { gastas }\end{array}$ & Diárias & $\begin{array}{c}\text { Custo } \\
\text { implantação } \\
\text { (R\$) }\end{array}$ & $\begin{array}{c}\text { Custo } \\
\text { manutenção } \\
\text { (R\$) }\end{array}$ & $\begin{array}{l}\text { Total } \\
\text { (R\$) }\end{array}$ & $\begin{array}{c}\text { Administração } \\
(8 \%)\end{array}$ & $\begin{array}{l}\text { Total } \\
\text { (R\$) }\end{array}$ & $\begin{array}{l}\text { Total } \\
\text { (US\$) }\end{array}$ \\
\hline \multirow{10}{*}{ Manejo } & Matocompetição & 7 & 10 & 84 & 7.560 & 4.000 & 2.000 & 13.560 & 1.085 & 14.645 & 5.050 \\
\hline & Espaçamento & 7 & 7 & 42 & 3.780 & 2.000 & 1.000 & 6.780 & 542 & 7.322 & 2.525 \\
\hline & Adubação & 7 & 7 & 84 & 7.560 & 3.000 & 2.000 & 12.560 & 1.005 & 13.565 & 4.678 \\
\hline & Brotação & 7 & 7 & 8 & 720 & 3.000 & 1.000 & 4.720 & 378 & 5.098 & 1.758 \\
\hline & Desrama & 20 & 7 & 12 & 1.080 & 3.000 & 3.000 & 7.080 & 566 & 7.646 & 2.637 \\
\hline & Microbacias & 7 & 7 & 12 & 1.080 & 25.000 & 5.000 & 31.080 & 2.486 & 33.566 & 11.575 \\
\hline & Preparo do solo & 7 & 7 & 42 & 3.780 & 4.000 & 1.000 & 8.780 & 702 & 9.482 & 3.270 \\
\hline & Produtividade & 7 & 7 & 42 & 3.780 & 2.000 & 1.000 & 6.780 & 542 & 7.322 & 2.525 \\
\hline & Resíduos & 7 & 7 & 175 & 15.750 & 6.000 & 4.000 & 25.750 & 2.060 & 27.810 & 9.590 \\
\hline & Geoprocessamento & 1 & & 150 & 13.500 & - & - & 13.500 & 1.080 & 14.580 & 5.028 \\
\hline \multirow{7}{*}{ Melhoramento } & Progênie/proced. & 7 & 4 & 28 & 2.520 & 4.000 & 1.000 & 7.520 & 602 & 8.122 & 2.801 \\
\hline & Sementes & 7 & 4 & 28 & 2.520 & 4.000 & 1.000 & 7.520 & 602 & 8.122 & 2.801 \\
\hline & Teste clonal & 7 & 4 & 28 & 2.520 & 4.000 & 1.000 & 7.520 & 602 & 8.122 & 2.801 \\
\hline & Proteção & 7 & 4 & 28 & 2.520 & 4.000 & 1.000 & 7.520 & 602 & 8.122 & 2.801 \\
\hline & Viveiro & 1 & 8 & 16 & 1.440 & 2.000 & - & 3.440 & 275 & 3.715 & 1.281 \\
\hline & Biotecnologia & 1 & 1 & 20 & 1.800 & 3.000 & - & 4.800 & 384 & 5.184 & 1.788 \\
\hline & $\begin{array}{l}\text { Qualidade. da } \\
\text { madeira }\end{array}$ & 1 & 2 & 40 & 3.600 & 3.000 & - & 6.600 & 528 & 7.128 & 2.458 \\
\hline \multirow{2}{*}{ Ambiência } & Conservação & 7 & 4 & 28 & 2.520 & 4.000 & 1.000 & 7.520 & 602 & 8.122 & 2.801 \\
\hline & Ambiência & 7 & 4 & 28 & 2.520 & 4.000 & 1.000 & 7.520 & 602 & 8.122 & 2.801 \\
\hline Mecanização & Mecanização & 0,5 & 5 & 30 & 2.700 & - & - & 2.700 & 216 & 2.916 & 1.006 \\
\hline
\end{tabular}

Fonte: Departamento de Tecnologia IPB.

Taxa do dólar : 2,90 
Aplicando-se os dados da Tabela 14 no levantamento dos projetos, obtém-se a análise do comportamento dos investimentos ao longo do tempo. Esses valores foram obtidos pela multiplicação do valor encontrado na Tabela 14, pelo número de projetos no mesmo período (Figura 22). O resultado é apresentado na Figura 29.

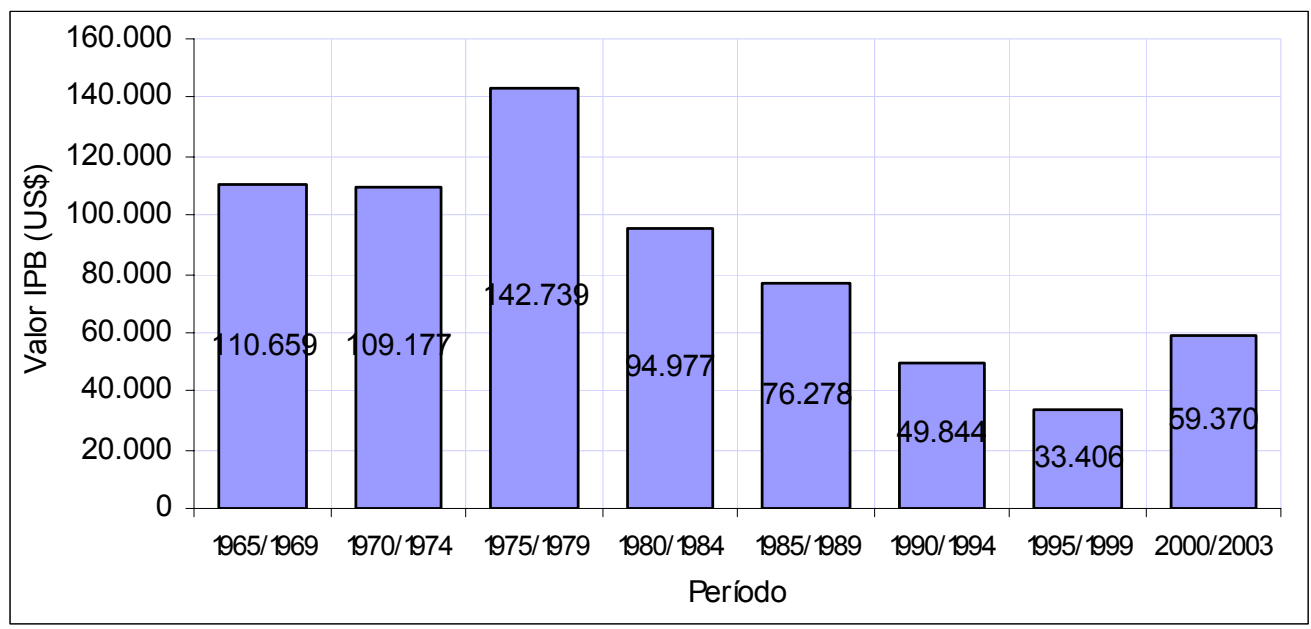

Figura 29 - Valores estimados para investimentos em projetos pela IPB

Vale lembrar que os valores apresentados na Figura 29 não são os totais efetivamente investidos pela IP no período. Trata-se de uma estimativa do investimento apenas em projetos desenvolvidos dentro do modelo IPEF/IP de integração universidade-empresa de pesquisa. As tendências observadas permitem verificar a estabilidade dos valores no período de 1980/1984, com um aumento no período de 1975/1979, o que coincide com o período de maior número de projetos no IPEF. Após esse período, ocorreu uma tendência de queda até o período de 1995/1999. Esta tendência parece coerente com as observadas nos dados anteriores, uma vez que, até o período de 1980/1989, foram observados 157 projetos, ou seja, $79 \%$ do total de projetos levantados. Os valores correspondentes ao último período levantado também estão de acordo com o já constatado na Figura 28, em que, apesar de não haver uma série de dados maior, explicando o custo médio por experimento, observou-se um aumento no custo médio dos projetos nos últimos anos. Utilizando-se estes 
dados e considerando ainda a composição dos valores investidos no IPEF pela IPB, pôde-se estimar os valores totais investidos em pesquisa no IPEF em um período maior, conforme apresentado na Tabela 15.

Tabela 15. Levantamento das estimativas dos valores de investimento

\begin{tabular}{cccccc}
\hline Período & $\begin{array}{c}\text { (A) } \\
\text { Custo dos } \\
\text { projetos } \\
\text { (US\$) }\end{array}$ & $\begin{array}{c}\text { Fator usando } \\
\mathbf{2 0 0 0 / 2 0 0 3} \\
\text { como base }\end{array}$ & $\begin{array}{c}\text { (B) } \\
\text { Custo real } \\
\text { em } \\
\mathbf{2 0 0 0 / 2 0 0 3} \\
\text { (US\$) }\end{array}$ & $\begin{array}{c}\text { (D) } \\
\text { Custo } \\
\text { estimado } \\
\text { projetos } \\
\text { (US\$) }\end{array}$ & $\begin{array}{c}\text { (E) } \\
\text { Custo } \\
\text { estimado } \\
\text { Total } \\
\text { (US\$) }\end{array}$ \\
\hline $\mathbf{1 9 7 5 / 1 9 7 9}$ & 142.739 & 2,4 & - & 180.932 & 393.330 \\
$\mathbf{1 9 8 0 / 1 9 8 4}$ & 94.977 & 1,6 & - & 120.390 & 261.717 \\
$\mathbf{1 9 8 5 / 1 9 8 9}$ & 76.278 & 1,3 & - & 96.688 & 210.190 \\
$\mathbf{1 9 9 0 / 1 9 9 4}$ & 49.844 & 0,8 & - & 63.181 & 137.349 \\
$\mathbf{1 9 9 5 / 1 9 9 9}$ & 33.406 & 0,6 & - & 42.344 & 92.052 \\
$\mathbf{2 0 0 0 / 2 0 0 3}$ & 59.370 & 1 & 75.256 & 75.256 & 163.600 \\
\hline
\end{tabular}

(A) Valores estimados a partir do levantamento do custo médio dos projetos (Figura 28)

(B) Relação entre a estimativa de custos dos períodos de 1975/2003 e a estimativa de custo do período 2000/2003, tida como referência;

(C) Custo real dos projetos para o período $2000 / 2003$ (vide metodologia no item 3.4.);

(D) Custo estimado para o item projetos, obtido pela multiplicação de (B) por (C), fixo;

(E) Custo estimado total, estimado a partir da composição dos projetos (Figura 25). considerando ainda que os outros períodos possuem a mesma distribuição de valores.

A Figura 30 representa então os valores investidos pela empresa no IPEF.

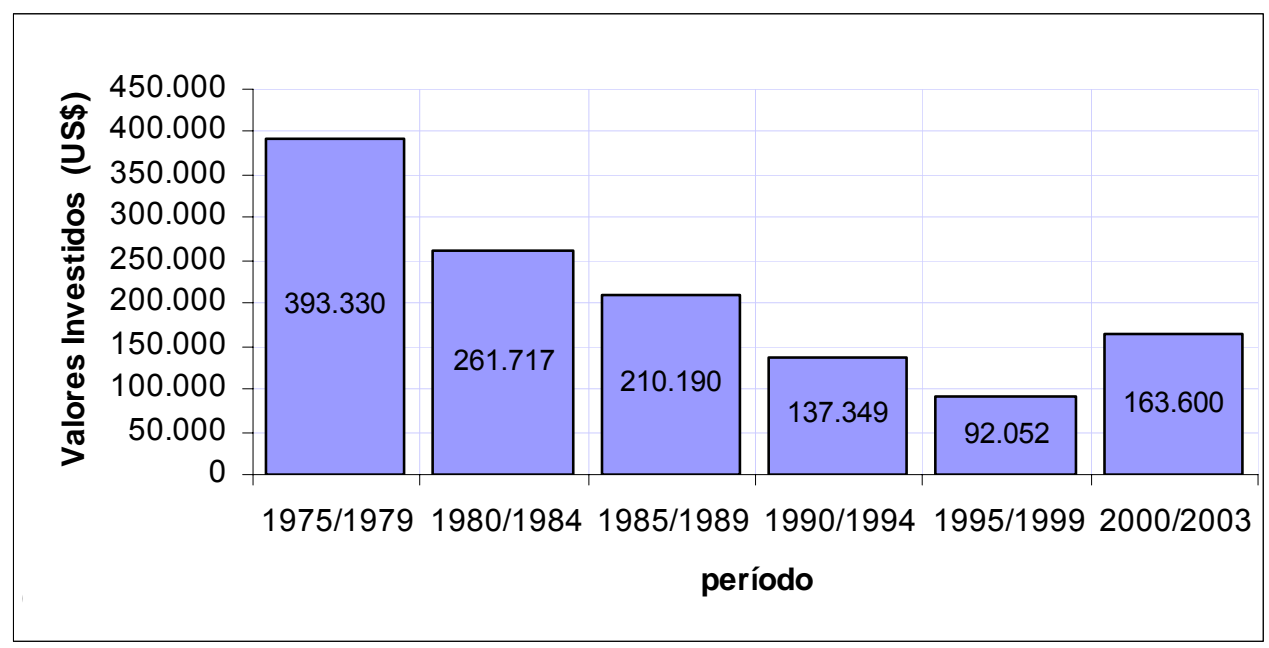

Figura 30 - Valores totais investidos pela International Paper no IPEF (US\$) 
Na Figura 31, apresentam-se os valores totais investidos pela empresa.

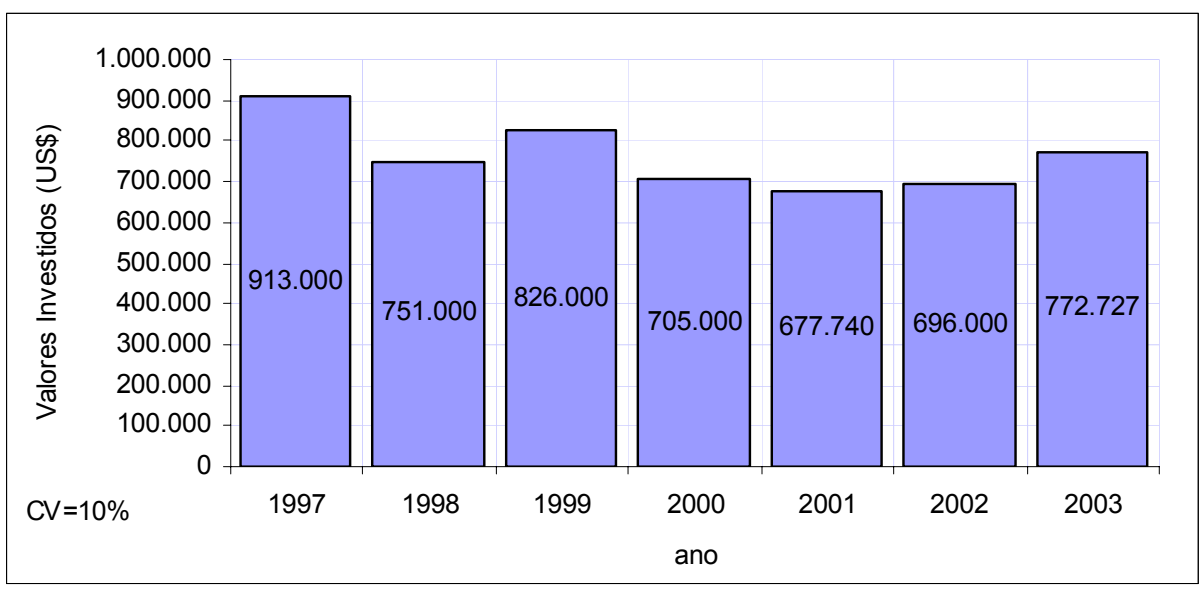

Figura 31 - Valores totais investidos pela IPB em pesquisa florestal

Fonte: Controladoria IPB

Observa-se (Figura 31) que os valores não tiveram uma grande variação de um ano para outro $(\mathrm{CV}=10 \%)$, portanto, pode-se assumir como verdadeiro que a média aritmética dos valores encontrados (US\$ 760.000) represente os investimentos por ano em pesquisa na IPB.

Com base nas informações apresentadas nas Figuras 30 e 31, foram calculados os percentuais dos valores investidos no IPEF em relação ao total investimento em pesquisa na empresa (Figura 32).

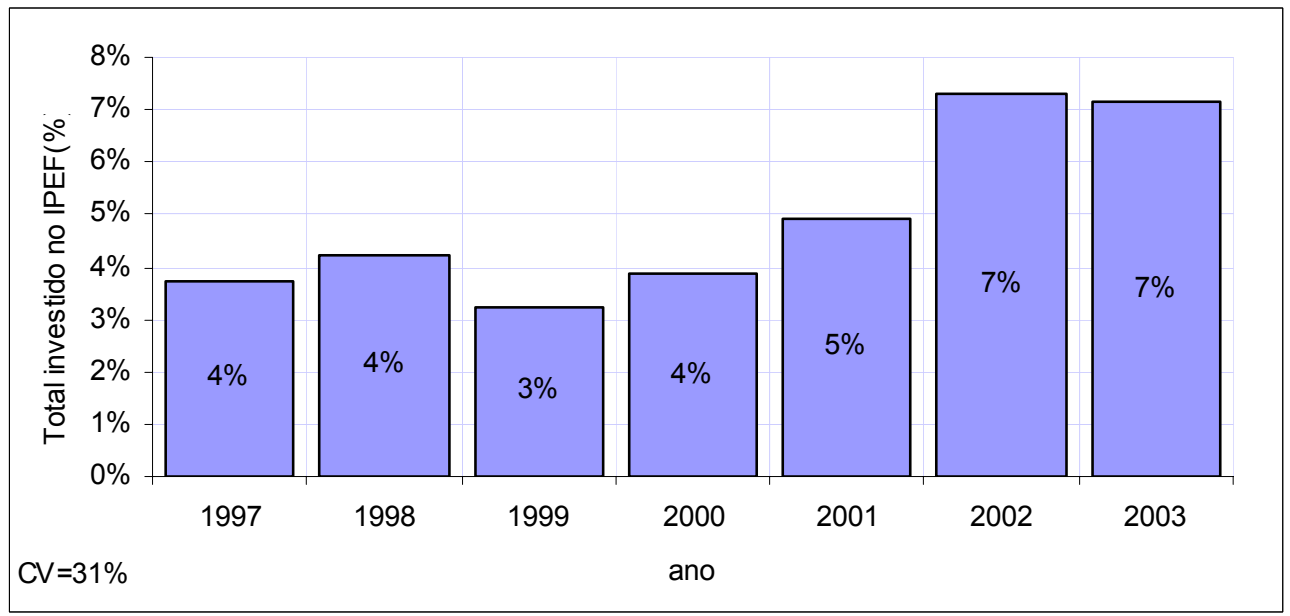

Figura 32 - Percentual investido no IPEF em relação ao total investido em pesquisa na empresa 
Observa-se, na Figura 32, uma tendência entre os anos de 1997/2001 de estabilidade, porém, quando se verifica o valor de 2002/2003 observa-se um aumento, confirmando as afirmações acima citadas na tendência das empresas de buscarem o IPEF em projetos que necessitem de recursos maiores ou conhecimento específico.

Outra informação, para efeito de comparação em trabalhos futuros, pode ser obtida por meio dos dados da Figura 33 e diz respeito ao percentual de investimento em pesquisa em relação ao custo total da celulose produzida.

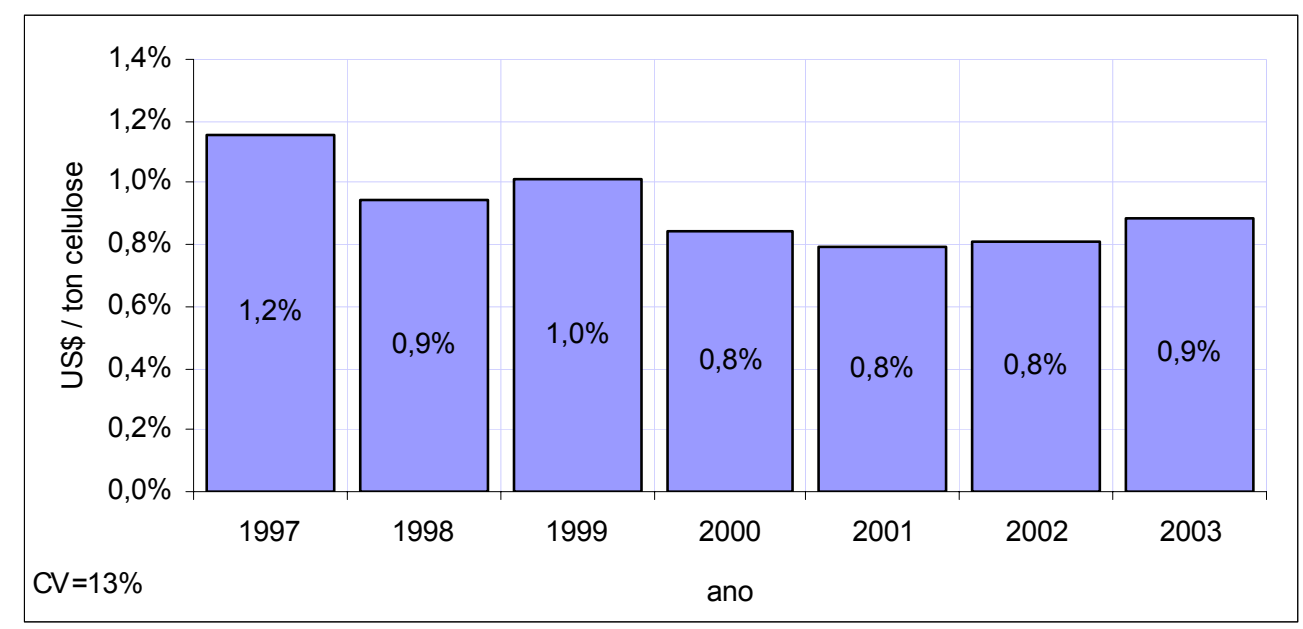

Figura 33 - Custo percentual da pesquisa na produção de celulose

\subsection{Análise dos benefícios financeiros}

Para o levantamento das estimativas do benefício financeiro da empresa em investimentos em pesquisa, foi utilizado o conceito de taxa interna de retorno.

Considera-se que os investimentos realizados em pesquisa pela empresa são corporativos, ou seja, são utilizados pela empresa nas outras unidades produtoras de florestas. Utilizou-se a Tabela 16 para alocação de recursos de investimento em pesquisa. 
Tabela 16. Alocação de investimentos na área de pesquisa

\begin{tabular}{ccccc}
\hline Período & São Paulo & Mato Grosso do Sul & Amapá & Paraná \\
\hline $\mathbf{1 9 7 5 / 1 9 7 9}$ & $100 \%$ & & & \\
$\mathbf{1 9 8 0 / 1 9 8 4}$ & $100 \%$ & & & \\
$\mathbf{1 9 8 5 / 1 9 8 9}$ & $80 \%$ & $20 \%$ & & \\
$\mathbf{1 9 9 0 / 1 9 9 4}$ & $70 \%$ & $30 \%$ & & \\
$\mathbf{1 9 9 5 / 1 9 9 9}$ & $60 \%$ & $20 \%$ & $20 \%$ & \\
$\mathbf{2 0 0 0 / 2 0 0 4}$ & $60 \%$ & $10 \%$ & $20 \%$ & $10 \%$ \\
\hline
\end{tabular}

Fonte: Departamento de Pesquisa IP

Considerou-se que os valores investidos nos períodos anteriores são representados pelos valores médios, oriundos da Figura 31 .

Com base nos dados e considerações apresentadas, pode-se, então, calcular os retornos para pesquisa na International Paper do Brasil, conforme Tabela 17.

Tabela 17. Fluxo de caixa para retorno em pesquisa na IPB

\begin{tabular}{|c|c|c|c|c|c|c|}
\hline & (A) & (B) & (C) & (D) & (E) & (F) \\
\hline Período & $\begin{array}{c}\text { Valores } \\
\text { investidos } \\
\text { (US\$) }\end{array}$ & $\begin{array}{c}\text { Variação } \\
\text { no IMA } \\
\text { (m²/ha/ano) }\end{array}$ & $\begin{array}{c}\text { Incremento } \\
\left(\mathrm{m}^{3} / \mathrm{ha}\right)\end{array}$ & $\begin{array}{c}\text { Preço } \\
\text { madeira } \\
\text { (US\$/m3) }\end{array}$ & $\begin{array}{c}\text { Receita } \\
\text { (US\$) }\end{array}$ & $\begin{array}{l}\text { Saldo } \\
\text { (US\$) }\end{array}$ \\
\hline $1975 / 1979$ & 3.800 .000 & 0 & 0 & & 0 & -3.800 .000 \\
\hline $1980 / 1984$ & 3.800 .000 & 1 & 7 & 5,51 & 1.156 .827 & -2.643 .173 \\
\hline $1985 / 1989$ & 3.040 .000 & 5 & 35 & 6,33 & 6.646 .710 & 3.606 .710 \\
\hline 1990/1994 & 2.660 .000 & 5 & 35 & 6,25 & 6.557 .880 & 3.897 .880 \\
\hline $1995 / 1999$ & 2.280 .000 & 3 & 21 & 8,12 & 5.116 .860 & 2.836 .860 \\
\hline $2000 / 2004$ & 2.280 .000 & 1 & 7 & 8,66 & 1.818 .653 & -461.348 \\
\hline \multicolumn{7}{|c|}{$\begin{array}{l}\text { (A) Valor obtido multiplicando-se os investimentos por período (Figura 28), pela estratégia de } \\
\text { alocação de recursos (Tabela 16); } \\
\text { (B) Variação do incremento em produtividade (Figura 09); } \\
\text { (C) Multiplicação de (B) pela rotação média ( } 7 \text { anos); } \\
\text { (D) Preço da madeira (Figura 14); } \\
\text { (E) Receita, considerando a multiplicação do incremento (C) pelo preço da madeira (D) e pela } \\
\text { área plantável da empresa ( } 30.000 \text { ha); } \\
\text { (F) Subtração da receita pelos valores investidos (A). }\end{array}$} \\
\hline
\end{tabular}


Os resultados do fluxo de caixa são apresentados na Tabela 18.

Tabela 18. Resultados da análise econômica para o fluxo de caixa

\begin{tabular}{cc}
\hline Taxa de desconto & $8 \%$ \\
\hline VPL & 1.583 .560 \\
TIR & $19,50 \%$ \\
\hline
\end{tabular}

Com base nestas informações, pode-se afirmar que:

a) os investimentos feitos em pesquisa pela empresa são altamente justificáveis, uma vez que o retorno mínimo para novos projetos na empresa é, atualmente, de $15 \%$;

b) os retornos não consideram variáveis indiretas, portanto, esperam-se valores maiores se forem considerados outros benefícios, como, por exemplo, os modelos propostos neste trabalho de redução da área plantada ou aumento da participação própria no consumo de madeira;

c) como já discutido anteriormente, dificilmente pode-se estimar o benefício dos investimentos realizados com o objetivo de manutenção da produtividade;

d) os valores de preço de madeira representam os valores de mercado da região onde a empresa exerce forte domínio; estes valores são notadamente menores que os valores médios de mercado pagos por outras empresas de papel e celulose no estado de São Paulo. 


\section{CONCLUSÕES}

Considerando-se cada hipótese formulada no início do trabalho, é possível concluir que:

Hipótese A

Observou-se aumento da produtividade e melhoria na qualidade, medidas pela variação observada no incremento médio anual das florestas e na taxa de conversão madeira/celulose, respectivamente. Esses ganhos devemse, em grande parte, às pesquisas voltadas para o aumento e manutenção da produtividade (manejo, ambiência, melhoramento) e para a melhoria do material genético (melhoramento, qualidade da madeira), utilizando-se da clonagem como a principal ferramenta. Pode-se ainda verificar a adoção das tecnologias desenvolvidas por meio da criação do índice de aplicabilidade.

Hipótese B

Confirmou-se, inicialmente, uma grande concentração de trabalhos nas áreas de melhoramento e manejo. Posteriormente, houve uma migração das necessidades de pesquisas para as áreas de ambiência e qualidade da madeira. Em termos de subáreas, observou-se a mesma tendência, com a evolução ocorrendo de temas como melhoramento clássico e adubação, para biotecnologia e temas voltados à sustentabilidade. Observou-se também que as pesquisas nas áreas de melhoramento e manejo foram absorvidas para desenvolvimento interno da empresa. 
Hipótese C

Observou-se uma tendência de queda no volume total dos investimentos em pesquisa no modelo universidade-empresa. Entretanto, pôde-se notar que, apesar do número de projetos ter se mantido constante nos últimos anos, houve um aumento do custo. Este aumento foi provocado pelo desenvolvimento de projetos que necessitem de investimentos maiores, comprovado pelo aumento do custo médio e verificado em áreas que exigem conhecimento específico, alto custo de análise e longo tempo de desenvolvimento.

Hipótese D

Os resultados apresentados corroboraram a hipótese formulada, uma vez que, considerando apenas os benefícios diretos, o retorno estimado de $19,5 \%$ é maior que a taxa de retorno recomendada pela empresa para os seus investimentos em novos projetos (15\%).

Para a elaboração deste trabalho ficaram claras algumas dificuldades, principalmente aquelas relacionadas à coleta das informações.

Em função da inexistência de uma base única e segura com informações a respeito dos projetos e resultados, recomenda-se a criação de bancos estruturados para o armazenamento dessas e outras informações que possam ser importantes na análise dos projetos. Como exemplo, são informações relevantes àquelas que possam contribuir para a construção de modelos de análise dos investimentos utilizando variáveis indiretas, tais como horas de análise, trabalhos publicados, adoção da tecnologia, número de pesquisadores, resultados experimentais, prazo do experimento etc.

Sugere-se também o armazenamento dos valores investidos em pesquisa florestal, bem como uma classificação com relação ao destino do investimento (análises, salários e benefícios, experimento, coleta das informações etc). 
O uso dessas informações pode trazer benefícios na alocação de recursos em áreas com maior retorno ou eficiência e na justificativa para novos projetos.

É também importante a criação indicadores que melhor avaliem o benefício da adoção das tecnologias geradas e ou a utilização dos conhecimentos adquiridos.

Com relação ao modelo IPEF de integração universidade-empresa, destacam-se os seguintes comentários:

a) em relação à estratégia de atuação do IPEF, observou-se, no estudo de caso, uma preferência da empresa, nos últimos anos, de priorizar convênios em áreas pré-competitivas, ou áreas nas quais ela não dispõe de recursos para realizar esses trabalhos, sejam eles de conhecimento específico por parte dos pesquisadores, de laboratórios com equipamentos e outros. São exemplos de projetos dessa natureza os desenvolvidos nas áreas de biotecnologia e genômica;

b) o IPEF é tido como um grande centro de referência, em termos de qualidade e conhecimento dentro das empresas. Essa referência pode ser utilizada como geradora de receita na forma de serviços prestados, uma vez que muitas empresas não estão dispostas a investir altos valores em estrutura de pesquisa específica, tais como laboratórios de análise e manutenção de mão-de-obra especializada e;

c) recomenda-se ênfase nos esforços de transferência de conhecimento. Estes investimentos devem ser feitos na forma de treinamentos, cursos, workshops, simpósios e seminários, promovendo a integração entre estudantes e professores com pesquisadores e executivos da empresa, promovendo o debate e a discussão de temas voltados à área florestal e provendo a universidade de ferramentas de extensão.

Em relação à estratégia recomendada para a International Paper do Brasil, destacam-se os seguintes comentários: 
a) a decisão de investimentos em laboratórios e estruturas de pesquisa específicas deve considerar a utilização (demanda de serviços) desses laboratórios, uma vez que, feito o investimento, existe a necessidade de alocação de mão-de-obra específica e treinada, além da manutenção da estrutura. Esses investimentos, quando não utilizados, provocam um aumento do custo fixo. Outro ponto a ser considerado é a não mobilidade da mudança de estratégia por parte da empresa;

b) decisões de parcerias em áreas específicas devem não apenas levar em consideração os custos, uma vez que aspectos ligados à qualidade e à mobilidade na transferência desses investimentos para outras áreas devem ser considerados. Exemplo disso são os investimentos em universidades, na formação de profissionais que futuramente podem ser contratados pela empresa (capacitação);

c) deve-se continuar dando ênfase aos esforços internos de pesquisa no desenvolvimento de projetos competitivos ou em áreas que exijam conhecimentos já disponíveis, tais como melhoramento e manejo;

d) investimentos em áreas cooperativas devem ser predefinidos, principalmente em áreas de alta especificidade e necessidade de recursos;

e) recomenda-se a manutenção do atual modelo universidade-empresa de investimento em pesquisa, com as necessárias modificações e revisões que melhor adeqüem-se às estratégias de pesquisa da empresa.

Estas recomendações podem ser inseridas nos respectivos planos diretores do IPEF e da IPB, para possíveis adaptações ou mudanças na estratégia de atuação.

Sugere-se ainda que trabalhos futuros se aprofundem no resgate de dados e entrevistas com os personagens que fizeram a história do IPEF nestes últimos 35 anos. Apesar das 40 horas de conversas com pesquisadores da universidade, do IPEF e com executivos que atuaram na empresa, esta dissertação teria retratado a evolução com mais acuidade se considerado um 
resgate mais extensivo e aprofundado de dados diretamente com esses personagens. Outro ponto a ser aprofundado diz respeito à análise individual de cada projeto, buscando-se correlações mais acuradas dos resultados obtidos.

Apesar da vasta bibliografia de retorno em pesquisa florestal consultada, em função da dificuldade de obtenção dos dados e do modelo de estudo de caso adotado, não foi possível a aplicação dos métodos descritos. A contribuição deste estudo seria maior se pudessem ser contabilizados os benefícios indiretos proporcionados pelo modelo universidade-empresa de investimento em pesquisa, tais como:

a) os ganhos em transferência de tecnologia para outras regiões do país por meio do efeito difusor da formação típico da universidade e da abrangência de atuação da International Paper no Brasil;

b) o aumento do conhecimento florestal dos pesquisadores envolvidos com este convênio, ao longo dos 35 anos de existência;

c) a importância social de ferramentas de pesquisa e experimentação; inclusive de qualidade de vida das pessoas envolvidas no processo florestal;

d) a importância dessas tecnologias geradas para o desenvolvimento florestal e do papel desse na economia do Brasil. 
ANEXOS 
Tabela 19. Levantamento dos projetos do IPEF

\begin{tabular}{|c|c|c|c|}
\hline Título do projeto (vínculo temático) & Grupo & Subgrupo & $\begin{array}{c}\text { Data } \\
\text { início }\end{array}$ \\
\hline $\begin{array}{l}\text { Estudos das variações botânicas em povoamentos } \\
\text { de Eucalyptus alba Reinw, Eucalyptus saligna Smith, } \\
\text { E. grandis Hill Ex Maiden e E. propinqua Deane and } \\
\text { Maiden }\end{array}$ & Melhoramento & & $1965 / 1969$ \\
\hline Teste de progênie de Eucalyptus Alba & Melhoramento & Melhoramento & $1965 / 1969$ \\
\hline Adubação parcelada em touças de $E$. saligna & Manejo & Adubação & $1965 / 1969$ \\
\hline $\begin{array}{l}\text { Ensaio sobre enxertia de Pinus caribaea var caribaea } \\
\text { e P. caribaea - Horto Nossa Senhora Aparecida - } \\
\text { Mogi Guaçu,SP }\end{array}$ & Melhoramento & & $1965 / 1969$ \\
\hline Adubação de touças de E. saligna & Manejo & Adubação & $1965 / 1969$ \\
\hline $\begin{array}{l}\text { Introdução de espécies e procedências na área } \\
\text { ecológica de Casa Branca (Fazenda Areia Branca) }\end{array}$ & Melhoramento & Melhoramento & $1965 / 1969$ \\
\hline $\begin{array}{l}\text { Comportamento das espécies/procedências em } \\
\text { função das condições edáficas ( } 2 \text { projetos) }\end{array}$ & Melhoramento & Melhoramento & $1965 / 1969$ \\
\hline $\begin{array}{l}\text { Resultados de ensaios de introdução de espécies de } \\
\text { Eucalyptus na região Centro-Sul }\end{array}$ & Melhoramento & Melhoramento & $1965 / 1969$ \\
\hline $\begin{array}{l}\text { Introdução de espécies e procedências na área } \\
\text { ecológica de Mogi Guaçu (Fazendas } \text { St }^{\mathrm{a}} \text { Terezinha e } \\
\text { N.Sa. Aparecida) }\end{array}$ & Melhoramento & Melhoramento & $1965 / 1969$ \\
\hline $\begin{array}{l}\text { "Áreas de produção e coleta de sementes" de } E \text {. } \\
\text { grandis nos hortos de Mogi Guaçu e Gigante }\end{array}$ & Melhoramento & Sementes & $1965 / 1969$ \\
\hline $\begin{array}{l}\text { Estudo da variação da densidade básica da madeira } \\
\text { de Eucalyptus alba Reiw e Eucalyptus saligna Smith }\end{array}$ & Tecnologia & $\begin{array}{l}\text { Qualidade da } \\
\text { madeira }\end{array}$ & $1965 / 1969$ \\
\hline $\begin{array}{l}\text { Seleção e instalação de populações para a produção } \\
\text { de sementes - Instalação de APS de E. grandis } \\
\text { Coff's Harbour (horto Mogi-Guaçu e Horto Gigante) }\end{array}$ & Melhoramento & Sementes & $1965 / 1969$ \\
\hline $\begin{array}{l}\text { Pomar de sementes de Pinus Caribaea var caribaea } \\
\text { por clones - Horto Nossa Senhora Aparecida - Mogi } \\
\text { Guaçu,SP }\end{array}$ & Melhoramento & Sementes & $1965 / 1969$ \\
\hline $\begin{array}{l}\text { Ensaio sobre competição de espécies de Eucalyptus } \\
\text { (procedências Austrália e Rio Claro) Horto Nossa } \\
\text { Senhora Aparecida - Mogi Guaçu,SP }\end{array}$ & Melhoramento & Melhoramento & $1965 / 1969$ \\
\hline $\begin{array}{l}\text { Teste Conjugado de origens e progênies de } E \text {. } \\
\text { saligna - Horto Areia Branca - Casa Branca,SP }\end{array}$ & Melhoramento & $\begin{array}{l}\text { Plantio } \\
\text { experimental }\end{array}$ & $1965 / 1969$ \\
\hline $\begin{array}{l}\text { Ensaios sobre o comportamento de } 10(\mathrm{dez}) \text { espécies } \\
\text { típicas de Eucalyptus - Horto Areia Branca - Casa } \\
\text { Branca,SP }\end{array}$ & Melhoramento & Melhoramento & $1965 / 1969$ \\
\hline $\begin{array}{l}\text { Efeitos da ferramenta de corte sobre a regeneração } \\
\text { do eucalipto }\end{array}$ & Colheita & Brotação & $1970 / 1974$ \\
\hline $\begin{array}{l}\text { Estudo do comportamento florestal de } E \text {. saligna e } E \text {. } \\
\text { grandis da Austrália, em diversos espaçamentos }\end{array}$ & Manejo & Espaçamento & $1970 / 1974$ \\
\hline $\begin{array}{l}\text { Adubação de } E \text {. saligna e } E \text {. grandis sob diversos } \\
\text { espaçamentos e épocas de aplicação de adubo - } \\
\text { Produção de celulose tipo exportação }\end{array}$ & Manejo & Adubação & $1970 / 1974$ \\
\hline Fertilização fosfatada no plantio de E. Saligna & Manejo & Adubação & 1970/1974 \\
\hline
\end{tabular}


Tabela 19. Levantamento dos projetos do IPEF

\begin{tabular}{|c|c|c|c|}
\hline Título do projeto (vínculo temático) & Grupo & Subgrupo & $\begin{array}{c}\text { Data } \\
\text { início }\end{array}$ \\
\hline $\begin{array}{l}\text { Aspectos econômicos da fertilização fosfatada em } \\
\text { Eucaliptos }\end{array}$ & Manejo & Adubação & $1970 / 1974$ \\
\hline $\begin{array}{l}\text { Aspectos econômicos do emprego de fertilizantes } \\
\text { minerais na produção de madeira de Eucalyptus } \\
\text { saligna no estado de são Paulo }\end{array}$ & Manejo & Adubação & $1970 / 1974$ \\
\hline $\begin{array}{l}\text { Fertilização de NPK Ca e condução da brotação de } \\
\text { E. saligna }\end{array}$ & Manejo & Adubação & $1970 / 1974$ \\
\hline $\begin{array}{l}\text { Adubação de touças de E. saligna com e sem fogo, } \\
\text { com e sem calagem e aplicação de doses crescentes } \\
\text { de NPK }\end{array}$ & Manejo & Adubação & $1970 / 1974$ \\
\hline $\begin{array}{l}\text { Indução de pseudo-resistência em E. grandis ao } \\
\text { ataque de Costalimaita ferruginea, através da } \\
\text { incoporação de calcário e gesso no solo - Horto } \\
\text { Gigante }\end{array}$ & Melhoramento & Proteção & $1970 / 1974$ \\
\hline $\begin{array}{l}\text { Projeto de instalação de um pomar de sementes de } \\
\text { E. saligna Smith Horto Gigante - Mogi Guaçu, SP }\end{array}$ & Melhoramento & Sementes & $1970 / 1974$ \\
\hline $\begin{array}{l}\text { Condução de eucaliptais como alternativa de uso } \\
\text { (Resultados Preliminares) }\end{array}$ & Manejo & Brotação & $1970 / 1974$ \\
\hline $\begin{array}{l}\text { Comportamento das espécies / procedências em } \\
\text { função das condições edáficas ( } 1 \text { projeto) }\end{array}$ & Melhoramento & Melhoramento & $1970 / 1974$ \\
\hline $\begin{array}{l}\text { Resultados de testes de procedências de Eucalyptus } \\
\text { grandis e Eucalyptus saligna na região Centro-Sul }\end{array}$ & Melhoramento & Melhoramento & $1970 / 1974$ \\
\hline $\begin{array}{l}\text { or das árvores sobre a brotação das } \\
\text { to }\end{array}$ & Manejo & Brotação & $1970 / 1974$ \\
\hline $\begin{array}{l}\text { Espécies e procedências de Eucalyptus para solos } \\
\text { úmidos }\end{array}$ & Melhoramento & Melhoramento & $1970 / 1974$ \\
\hline $\begin{array}{l}\text { Teste de espécies e procedências de Eucalyptus em } \\
\text { terreno úmido (encosta) - Horto Nossa Senhora } \\
\text { Aparecida - Mogi Guaçu,SP }\end{array}$ & Melhoramento & Melhoramento & $1970 / 1974$ \\
\hline $\begin{array}{l}\text { Teste conjugado de origens e progênies de } E \text {. } \\
\text { saligna - Horto Areia Branca - Casa Branca,SP }\end{array}$ & Melhoramento & Melhoramento & $1970 / 1974$ \\
\hline $\begin{array}{l}\text { Ensaios sobre o comportamento de várias espécies } \\
\text { de Eucalytus - Horto Santa Terezinha - Mogi } \\
\text { Guaçu,SP }\end{array}$ & Melhoramento & Melhoramento & $1970 / 1974$ \\
\hline $\begin{array}{l}\text { Fertilização parcelada na produção de mudas de } \\
\text { eucalipto }\end{array}$ & Melhoramento & Viveiro & $1970 / 1974$ \\
\hline $\begin{array}{l}\text { Métodos de aplicação de adubo em touças de } \\
\text { Eucalyptus }\end{array}$ & Manejo & Adubação & $1970 / 1974$ \\
\hline $\begin{array}{l}\text { Ensaio sobre métodos de aplicação de adubo em } \\
\text { touças de eucalipto }\end{array}$ & Manejo & Adubação & $1970 / 1974$ \\
\hline $\begin{array}{l}\text { Área de produção de sementes de } P \text {. oocarpa } \\
\text { Schiedes -Areia Branca }\end{array}$ & Melhoramento & Sementes & $1970 / 1974$ \\
\hline $\begin{array}{l}\text { Instalação de APS de sementes de } P \text {. caribaea var } \\
\text { hodurensis - Areia Branca - Casa Branca,SP }\end{array}$ & Melhoramento & Sementes & $1970 / 1974$ \\
\hline Altura de corte em povoamentos de Eucalyptus & Manejo & Produtividade & 1970/1974 \\
\hline
\end{tabular}


Tabela 19. Levantamento dos projetos do IPEF

\begin{tabular}{|c|c|c|c|}
\hline Título do projeto (vínculo temático) & Grupo & Subgrupo & $\begin{array}{l}\text { Data } \\
\text { início }\end{array}$ \\
\hline $\begin{array}{l}\text { Importância da nebulização intermitente e efeito do } \\
\text { tratamento hormonal na formação de raízes em } \\
\text { estacas de eucaliptos }\end{array}$ & Melhoramento & Viveiro & $1970 / 1974$ \\
\hline $\begin{array}{l}\text { A viabilidade da utilização de herbicidas em florestas } \\
\text { implantadas de eucalipto }\end{array}$ & Manejo & $\begin{array}{c}\text { Matocompetiçã } \\
\text { o }\end{array}$ & $1970 / 1974$ \\
\hline $\begin{array}{l}\text { Influência da espécie, do espaçamento e da } \\
\text { adubação na produção de madeira de eucalipto }\end{array}$ & Melhoramento & & $1970 / 1974$ \\
\hline $\begin{array}{l}\text { Ensaio de procedência de Eucalyptus robusta em } \\
\text { solos hidromórficos - Horto Mogi Guaçu - Mogi } \\
\text { Guaçu,SP }\end{array}$ & Melhoramento & Melhoramento & $1970 / 1974$ \\
\hline $\begin{array}{l}\text { Teste de procedências de E. grandis e E. saligna - } \\
\text { Horto Santa Fé A - Brotas,SP }\end{array}$ & Melhoramento & Melhoramento & $1970 / 1974$ \\
\hline $\begin{array}{l}\text { Teste de procedências de E. camaldulensis em solos } \\
\text { hidromórficos }\end{array}$ & Melhoramento & Melhoramento & $1970 / 1974$ \\
\hline $\begin{array}{l}\text { Estudo comparativo das madeiras de Eucalyptus } \\
\text { saligna, E.paniculata, E. citriodora, E. maculata e } E \text {. } \\
\text { tereticornis para produção de celulose sulfato }\end{array}$ & Tecnologia & $\begin{array}{l}\text { Qualidade da } \\
\text { madeira }\end{array}$ & $1970 / 1974$ \\
\hline $\begin{array}{l}\text { Ensaio de adubação no plantio de Eucalyptus } \\
\text { grandis }\end{array}$ & Manejo & Adubação & $1970 / 1974$ \\
\hline $\begin{array}{l}\text { Conservação genética de uma população de Peroba } \\
\text { Rosa Aspidosperma polyneuron - através de } \\
\text { progênies de polinização livre - Horto Mogi Guaçu }\end{array}$ & Ambiência & Conservação & $1970 / 1974$ \\
\hline $\begin{array}{l}\text { Teste de procedência de E. camaldulensis Horto } \\
\text { Nossa Senhora Aparecida - Mogi Guaçu,SP }\end{array}$ & Melhoramento & Melhoramento & $1970 / 1974$ \\
\hline $\begin{array}{l}\text { Bases para o melhoramento genético da densidade } \\
\text { básica da madeira de Eucalyptus grandis Hill ex } \\
\text { Maiden }\end{array}$ & Tecnologia & $\begin{array}{l}\text { Qualidade da } \\
\text { madeira }\end{array}$ & $1975 / 1979$ \\
\hline $\begin{array}{l}\text { Ensaios com herbicidas, visando o controle de ervas } \\
\text { daninhas, em florestas implantadas de Pinus e } \\
\text { Eucalyptus }\end{array}$ & Manejo & $\begin{array}{l}\text { Matocompetiçã } \\
\text { o }\end{array}$ & $1975 / 1979$ \\
\hline $\begin{array}{l}\text { Plano de ensaio sobre época de adubação e forma } \\
\text { de aplicação do adubo no plantio de Eucalyptus } \\
\text { saligna }\end{array}$ & Manejo & Adubação & $1975 / 1979$ \\
\hline $\begin{array}{l}\text { Teste de progênie de E. saligna ( Austrália) Coff's } \\
\text { Harbour - Horto Santa Fé - Brotas,SP }\end{array}$ & Melhoramento & Melhoramento & $1975 / 1979$ \\
\hline $\begin{array}{l}\text { Introdução de E. andrewsii e E. cloeziana - Horto } \\
\text { Santa Fé B - Brotas,SP }\end{array}$ & Melhoramento & Melhoramento & $1975 / 1979$ \\
\hline $\begin{array}{l}\text { Efeito do parcelamento da adubação fundamental no } \\
\text { desenvolvimento de povoamentos de Eucalyptus } \\
\text { saligna (Mairinque) }\end{array}$ & Manejo & Adubação & $1975 / 1979$ \\
\hline $\begin{array}{l}\text { Efeito da época e forma de aplicação de fertilizantes } \\
\text { no plantio de Eucalyptus saligna }\end{array}$ & Manejo & Adubação & $1975 / 1979$ \\
\hline Análise foliar em 5 espécies de eucaliptos & & & \\
\hline $\begin{array}{l}\text { Variação genética em progênies de uma população } \\
\text { de Eucalyptus grandis (hill) maiden }\end{array}$ & Melhoramento & Melhoramento & $1975 / 1979$ \\
\hline $\begin{array}{l}\text { Estudo do comportamento de híbridos } \\
\text { interespecíficos de Eucalyptus }\end{array}$ & Melhoramento & Sementes & $1975 / 1979$ \\
\hline
\end{tabular}


Tabela 19. Levantamento dos projetos do IPEF

\begin{tabular}{|c|c|c|c|}
\hline Título do projeto (vínculo temático) & Grupo & Subgrupo & $\begin{array}{c}\text { Data } \\
\text { início }\end{array}$ \\
\hline $\begin{array}{l}\text { Ensaio sobre o parcelamento das adubações } \\
\text { fundamentais e sua influência no desenvolvimento } \\
\text { de povoamentos de Eucalyptus }\end{array}$ & Manejo & Adubação & $1975 / 1979$ \\
\hline $\begin{array}{l}\text { Ensaio sobre o parcelamento das adubações } \\
\text { fundamentais e sua influência no desenvolvimento } \\
\text { de povoamentos de Eucalyptus saligna }\end{array}$ & Manejo & Adubação & $1975 / 1979$ \\
\hline $\begin{array}{l}\text { Avaliação da resistência de progênies de E. grandis } \\
\text { a Cryphonectria cubensis (Horto Santa Fé) }\end{array}$ & Melhoramento & Melhoramento & $1975 / 1979$ \\
\hline $\begin{array}{l}\text { Teste de progênie de Eucalyptus grandis - Horto } \\
\text { Santa Fé - Brotas,SP }\end{array}$ & Melhoramento & Melhoramento & $1975 / 1979$ \\
\hline $\begin{array}{l}\text { Teste de progênie de Eucalyptus grandis - Horto } \\
\text { Santa Fé - Brotas,SP }\end{array}$ & Melhoramento & Melhoramento & $1975 / 1979$ \\
\hline $\begin{array}{l}\text { Estudo da densidades básicas Horto Santa Fé - } \\
\text { Brotas,SP }\end{array}$ & Tecnologia & $\begin{array}{l}\text { Qualidade da } \\
\text { madeira }\end{array}$ & $1975 / 1979$ \\
\hline $\begin{array}{l}\text { Estimativa do volume de madeira aproveitável para } \\
\text { celulose em povoamentos de Eucalyptus spp: estudo } \\
\text { da determinação do tamanho ideal de parcelas }\end{array}$ & Manejo & & $1975 / 1979$ \\
\hline $\begin{array}{l}\text { Variabilidade no crescimento e na densidade básica } \\
\text { da madeira de E. grandis (progênies de Rio Claro), } \\
\text { aos } 3 \text { anos de idade, em Mogi Guaçu }\end{array}$ & Tecnologia & $\begin{array}{l}\text { Qualidade da } \\
\text { madeira }\end{array}$ & $1975 / 1979$ \\
\hline $\begin{array}{l}\text { Efeito da poda na produção de sementes de } \\
\text { Eucalyptos grandis }\end{array}$ & Manejo & Desrama & $1975 / 1979$ \\
\hline $\begin{array}{l}\text { Varição da densidade básica nas secções } \\
\text { transversais do caule da base do tronco para a copa } \\
\text { de eucalipto }\end{array}$ & Tecnologia & $\begin{array}{l}\text { Qualidade da } \\
\text { madeira }\end{array}$ & $1975 / 1979$ \\
\hline $\begin{array}{l}\text { Teste de progênie de meios-irmãos de Eucalyptus } \\
\text { urophilla em área da Champion Papel e Celulose S.A }\end{array}$ & Melhoramento & Melhoramento & $1975 / 1979$ \\
\hline $\begin{array}{l}\text { Teste de progênie de E. urophylla Horto Mogi Guaçu } \\
\text { - Mogi Guaçu,SP }\end{array}$ & Melhoramento & Melhoramento & $1975 / 1979$ \\
\hline $\begin{array}{l}\text { Introdução de espécies e procedências conhecida de } \\
\text { E. pilulari,s E. pellita e E. grandis Horto Água } \\
\text { Virtuosa,SP }\end{array}$ & Melhoramento & Melhoramento & $1975 / 1979$ \\
\hline $\begin{array}{l}\text { Um novo método de melhoramento em eucalipto: } \\
\text { "Área de produção de sementes especial" }\end{array}$ & Melhoramento & Sementes & $1975 / 1979$ \\
\hline $\begin{array}{l}\text { Classificação automática de reflorestamentos de } \\
\text { Pinus spp e Eucalyptos spp. em Mogi Guaçu, SP, } \\
\text { utilizando dados do satélite Landsat. }\end{array}$ & Manejo & $\begin{array}{l}\text { Geoprocessam } \\
\text { ento }\end{array}$ & $1975 / 1979$ \\
\hline $\begin{array}{l}\text { Extração e exportação de nutrientes pelo Eucalyptus } \\
\text { grandis hill ex-maiden em função da idade: } 1 \text { - } \\
\text { macronutrientes }\end{array}$ & Manejo & Adubação & $1975 / 1979$ \\
\hline $\begin{array}{l}\text { Extração e exportação de nutriente pelo Eucalyptus } \\
\text { grandis hill ex-maiden em função da idade: } 2 \text { - } \\
\text { micronutrientes }\end{array}$ & Manejo & Adubação & $1975 / 1979$ \\
\hline $\begin{array}{l}\text { Teste de transmissibilidade do agente causal da } \\
\text { gomose ("Pau Preto") do Eucalyptus grandis (Coff's } \\
\text { Harbour) }\end{array}$ & Melhoramento & Proteção & $1975 / 1979$ \\
\hline Teste de progênie de Eucalyptus saligna & Melhoramento & Melhoramento & 1975/1979 \\
\hline
\end{tabular}


Tabela 19. Levantamento dos projetos do IPEF

\begin{tabular}{|c|c|c|c|}
\hline Título do projeto (vínculo temático) & Grupo & Subgrupo & $\begin{array}{c}\text { Data } \\
\text { início }\end{array}$ \\
\hline $\begin{array}{l}\text { A variação da densidade básica da madeira de } \\
\text { Eucalyptus spp, em função da idade e qualidade de } \\
\text { local }\end{array}$ & Tecnologia & $\begin{array}{l}\text { Qualidade da } \\
\text { madeira }\end{array}$ & $1975 / 1979$ \\
\hline $\begin{array}{l}\text { Densidade básica de madeira de Eucalyptus grandis } \\
\text { hill ex maiden, aos } 3 \text { anos de idade }\end{array}$ & Tecnologia & $\begin{array}{l}\text { Qualidade da } \\
\text { madeira }\end{array}$ & $1975 / 1979$ \\
\hline $\begin{array}{l}\text { Características das fibras de madeira de Eucalyptus } \\
\text { grandis hill ex maiden, aos } 3 \text { anos de idade. }\end{array}$ & Tecnologia & $\begin{array}{l}\text { Qualidade da } \\
\text { madeira }\end{array}$ & $1975 / 1979$ \\
\hline $\begin{array}{l}\text { Efeito de colméias de Apis mellifera I. em pomar de } \\
\text { sementes de Eucalyptus saligna Smith }\end{array}$ & Melhoramento & Sementes & $1975 / 1979$ \\
\hline $\begin{array}{l}\text { Desenvolvimento floral de Eucalyptus grandis Hill ex } \\
\text { Maiden em Mogi Guaçu - SP }\end{array}$ & Melhoramento & Sementes & $1975 / 1979$ \\
\hline $\begin{array}{l}\text { Maturação fisiológica de sementes de Eucalyptus } \\
\text { grandis Hill ex Maiden }\end{array}$ & Melhoramento & Sementes & $1975 / 1979$ \\
\hline $\begin{array}{l}\text { Estudo da dispersão de pólen de Eucalyptus saligna } \\
\text { Smith por abelhas Apis mellifera I. utilizando-se o } \\
\text { radiofósforo }{ }^{32} \text { p. }\end{array}$ & Melhoramento & Sementes & $1975 / 1979$ \\
\hline $\begin{array}{l}\text { Produção de sementes de Eucalyptus grandis efeitos } \\
\text { da intensidade de seleção e de condições de } \\
\text { polinização - Horto Mogi Guaçu }\end{array}$ & Melhoramento & Sementes & $1975 / 1979$ \\
\hline $\begin{array}{l}\text { Influência da fertilização potássica sobre a } \\
\text { sobrevivência e crescimento do Eucalyptus grandis }\end{array}$ & Manejo & Adubação & $1975 / 1979$ \\
\hline $\begin{array}{l}\text { Plantações energéticas específicas para a produção } \\
\text { de energia }\end{array}$ & Tecnologia & $\begin{array}{l}\text { Qualidade da } \\
\text { madeira }\end{array}$ & $1975 / 1979$ \\
\hline Seleção genética do E. decaisneana & Melhoramento & Melhoramento & $1975 / 1979$ \\
\hline $\begin{array}{l}\text { Produção de sementes de E. grandis : Efeitos de } \\
\text { Intensidade de seleção e de condições de } \\
\text { polinização - Horto Mogi Guaçu - Mogi Guaçu,SP }\end{array}$ & Melhoramento & Sementes & $1975 / 1979$ \\
\hline $\begin{array}{l}\text { Influência da posição da árvore no banco clonal e da } \\
\text { posição dos ramos na copa na frutificação - Horto } \\
\text { Areia Branca - Casa Branca,SP }\end{array}$ & Melhoramento & Sementes & $1975 / 1979$ \\
\hline $\begin{array}{l}\text { Dispersão de pólen de Eucalyptus saligna Smith por } \\
\text { Apis mellifera } 1758 \text { (Hymenoptera, Apidae) - Horto } \\
\text { Areai Branca - Casa Branca,SP }\end{array}$ & Melhoramento & Sementes & $1975 / 1979$ \\
\hline $\begin{array}{l}\text { Ensaios sobre o comportamento de } 10(\mathrm{dez}) \text { espécies } \\
\text { típicas de Eucalyptus. Horto Mogi Guaçu - Mogi } \\
\text { Guaçu,SP }\end{array}$ & Melhoramento & Melhoramento & $1975 / 1979$ \\
\hline $\begin{array}{l}\text { Densidade básica da madeira de plantações } \\
\text { comerciais de Eucalyptus, na região de Mogi-Guaçu } \\
\text { (SP) }\end{array}$ & Tecnologia & $\begin{array}{l}\text { Qualidade da } \\
\text { madeira }\end{array}$ & $1975 / 1979$ \\
\hline $\begin{array}{l}\text { O interplantio como alternativa para rotações } \\
\text { sucessivas em Eucalyptus }\end{array}$ & Manejo & Brotação & $1975 / 1979$ \\
\hline $\begin{array}{l}\text { Estudo da eficiência de agentes polinizantes } \\
\text { (abelhas) em APS de E. grandis Horto Gigante Mogi } \\
\text { Guaçu,SP }\end{array}$ & Melhoramento & Sementes & $1980 / 1984$ \\
\hline $\begin{array}{l}\text { A produção de sementes melhoradas de espécies } \\
\text { florestais, com ênfase em Eucalyptus }\end{array}$ & Melhoramento & Sementes & $1980 / 1984$ \\
\hline
\end{tabular}


Tabela 19. Levantamento dos projetos do IPEF

\begin{tabular}{|c|c|c|c|}
\hline Título do projeto (vínculo temático) & Grupo & Subgrupo & $\begin{array}{c}\text { Data } \\
\text { início }\end{array}$ \\
\hline $\begin{array}{l}\text { Estudos de fertilização Mineral em APS - Horto Mogi } \\
\text { Guaçu - Mogi Guaçu,SP }\end{array}$ & Manejo & Adubação & 1980/1984 \\
\hline $\begin{array}{l}\text { Escoamento superficial, perdas de solo e de } \\
\text { nutrientes em microparcelas reflorestadas com } \\
\text { eucalipto em solos arenosos no muncípio de São } \\
\text { Simão, SP. [Runoff, erosão e perdas de nutrientes } \\
\text { do solo] }\end{array}$ & Ambiência & Microbacias & $1980 / 1984$ \\
\hline $\begin{array}{l}\text { Utilização dos resíduos da fábrica nas plantações } \\
\text { florestais }\end{array}$ & Manejo & Resíduos & $1980 / 1984$ \\
\hline Avaliação e seleção de espécies procedências aptas & Melhoramento & Melhoramento & $1980 / 1984$ \\
\hline Run Off, erosão e perdas de nutrientes do solo & Ambiência & & 984 \\
\hline $\begin{array}{l}\text { Produção de sementes em brotações de Eucalyptus } \\
\text { grandis - Horto Mogi Guaçu - Mogi Guaçu,SP }\end{array}$ & Melhoramento & Sementes & $1980 / 1984$ \\
\hline $\begin{array}{l}\text { Efeito do cálcio (Ca) na germinação do pólen - } \\
\text { Laboratório/Horto Mogi Guaçu - Mogi Guaçu,SP }\end{array}$ & Melhoramento & Sementes & $1980 / 1984$ \\
\hline $\begin{array}{l}\text { Efeito do Ca, Tween e da interação de ambos na } \\
\text { emissão do tubo polínico - Laboratório/Horto Mogi } \\
\text { Guaçu - Mogi Guaçu,SP }\end{array}$ & Melhoramento & Sementes & $1980 / 1984$ \\
\hline $\begin{array}{l}\text { Estudo do espaçamento de plantio e idade de corte } \\
\text { de eucalipto para produção de lenha }\end{array}$ & Manejo & Espaçamento & $1980 / 1984$ \\
\hline $\begin{array}{l}\text { Fertilização mineral no plantio de eucalipto em solos } \\
\text { marginais }\end{array}$ & Manejo & Adubação & $1980 / 1984$ \\
\hline $\begin{array}{l}\text { Ciclagem de nutrientes e manutenção da } \\
\text { produtividade do sítio em áreas marginais }\end{array}$ & Manejo & Produtividade & $1980 / 1984$ \\
\hline Determinação de produtividade de biomassa & Manejo & & 1980/1984 \\
\hline Preparo do solo de várzea para o plantio de eucalipto & Manejo & $\begin{array}{l}\text { Preparo do } \\
\text { solo }\end{array}$ & $1980 / 1984$ \\
\hline $\begin{array}{l}\text { Germinação do pólen de Eucalyptus spp em função } \\
\text { da forma com que o pólen é colocado sobre o meio } \\
\text { de cultura (em suspensão ou direta/ e. da antera ao }\end{array}$ & Melhoramento & Sementes & $1980 / 1984$ \\
\hline $\begin{array}{l}\text { meio Laboratório/Horto Mogi Guaçu - Mogi } \\
\text { Guaçu,SP }\end{array}$ & & & \\
\hline $\begin{array}{l}\text { Teste de germinação do pólen de } \\
\text { espalhado urophylla } \\
\text { diretamente sobre } \quad \text { o meio }\end{array}$ & Melhoramento & Sementes & $1980 / 1984$ \\
\hline Laboratório/Horto Mogi Guaçu - Mogi Guaçu,SP & & & \\
\hline $\begin{array}{l}\text { Fungos termófilos em pilhas de cavacos de } \\
\text { Eucalyptus spp com auto-aquecimento }\end{array}$ & Melhoramento & Proteção & $1980 / 1984$ \\
\hline $\begin{array}{l}\text { Caracterização hidrológica do solo hidromórfico de } \\
\text { Mogi Guaçu: regime da água subterrânea }\end{array}$ & Ambiência & hidrologia & $1980 / 1984$ \\
\hline $\begin{array}{l}\text { Implicações ecológicas do uso de áreas marginais } \\
\text { (cerrado) }\end{array}$ & Ambiência & & $1980 / 1984$ \\
\hline $\begin{array}{l}\text { Comportamento de híbridos naturais frente ao seu } \\
\text { uso energético }\end{array}$ & Tecnologia & $\begin{array}{l}\text { Qualidade da } \\
\text { madeira }\end{array}$ & $1980 / 1984$ \\
\hline $\begin{array}{l}\text { Efeitos da "cinza" de biomassa florestal sobre a } \\
\text { produtividade de povoamentos puros de Eucalyptus } \\
\text { grandis e avaliação financeira }\end{array}$ & Manejo & Adubação & $1985 / 1989$ \\
\hline
\end{tabular}


Tabela 19. Levantamento dos projetos do IPEF

\begin{tabular}{|c|c|c|c|}
\hline Título do projeto (vínculo temático) & Grupo & Subgrupo & $\begin{array}{c}\text { Data } \\
\text { início }\end{array}$ \\
\hline $\begin{array}{l}\text { Uso de "cinza" de biomassa florestal como fonte de } \\
\text { nutrientes em povoamentos puros de Eucalyptus } \\
\text { grandis }\end{array}$ & Manejo & Adubação & $1985 / 1989$ \\
\hline $\begin{array}{l}\text { Efeitos da competição entre árvores na seleção de } \\
\text { árvores superiores de E. grandis }\end{array}$ & Melhoramento & Melhoramento & $1985 / 1989$ \\
\hline $\begin{array}{l}\text { Efeito da desfolha parcial e total na produçãode } \\
\text { biomassa de Eucalyptus grandis em Mogi Guaçu, } \\
\text { São Paulo }\end{array}$ & Manejo & Produtividade & $1985 / 1989$ \\
\hline $\begin{array}{l}\text { Efeito do desfolhamento no crescimento do } \\
\text { Eucalyptus grandis Hill ex Maiden (Myrtaceae) }\end{array}$ & Manejo & Produtividade & $1985 / 1989$ \\
\hline $\begin{array}{l}\text { Teste Clonal de E. urophilla, E. saligna, E. grandis e } \\
\text { E. alba para o Horto Santa Terezinha }\end{array}$ & Melhoramento & Teste Clonal & $1985 / 1989$ \\
\hline $\begin{array}{l}\text { Transferência de tecnologia para clonagem de } \\
\text { Eucalyptus através da técnica de cultura de tecidos }\end{array}$ & Melhoramento & Biotecnologia & $1985 / 1989$ \\
\hline $\begin{array}{l}\text { Programa cooperativo interação genótipo } x \\
\text { ambientes }\end{array}$ & Melhoramento & & $1985 / 1989$ \\
\hline $\begin{array}{l}\text { Detecção, identificação e controle de cupins em } \\
\text { plantio de Eucalyptus spp. }\end{array}$ & Melhoramento & Proteção & $1985 / 1989$ \\
\hline $\begin{array}{l}\text { Avaliação dos danos causados por desfolha parcial e } \\
\text { total de eucaliptos }\end{array}$ & Melhoramento & Proteção & $1985 / 1989$ \\
\hline $\begin{array}{l}\text { Efeito da serapilheira de Eucalyptus grandis no } \\
\text { crescimento micelial de Pisolithus tinctorius em meio } \\
\text { de cultura }\end{array}$ & Melhoramento & Proteção & $1985 / 1989$ \\
\hline $\begin{array}{l}\text { Prevenção e controle das rachaduras de topo em } \\
\text { tora de Eucalyptus grandis Hill ex Maiden }\end{array}$ & Tecnologia & & $1985 / 1989$ \\
\hline Desenvolvimento ectomicorrízico em mudas de & Melhoramento & Viveiro & $1985 / 1989$ \\
\hline $\begin{array}{l}\text { Eucalyptus grandis e Eucalyptus urophylla } \\
\text { inoculados com Pisolithus tinctorius em um viveiro } \\
\text { comercial }\end{array}$ & & & \\
\hline Casa de inimigos naturais & Melhoramento & Proteção & 1985/1989 \\
\hline Estudos na área de fitopatologia & Melhoramento & Proteção & 1985/1989 \\
\hline $\begin{array}{l}\text { Estrutura anatômica e composição química de } \\
\text { cavacos de madeira de eucalipto inoculados com o } \\
\text { fungo Thermoascus aurantiacus }\end{array}$ & Tecnologia & $\begin{array}{l}\text { Qualidade da } \\
\text { madeira }\end{array}$ & $1985 / 1989$ \\
\hline $\begin{array}{l}\text { Resultados preliminares sobre a utilização de cinza } \\
\text { provenientes da madeira de eucalipto, na segunda } \\
\text { rotação }\end{array}$ & Manejo & Adubação & $1985 / 1989$ \\
\hline $\begin{array}{l}\text { (1) Teste Clonal de E. grandis e E. urophilla para o } \\
\text { Horto Santa Fé }\end{array}$ & Melhoramento & Teste Clonal & $1985 / 1989$ \\
\hline Programa cooperativo em planejamento & Manejo & Produtividade & $1985 / 1989$ \\
\hline $\begin{array}{l}\text { Programa cooperativo de monitoramento de insetos } \\
\text { em florestas }\end{array}$ & Melhoramento & Proteção & $1985 / 1989$ \\
\hline $\begin{array}{l}\text { Centro de conservação genética e melhoramento de } \\
\text { pinheiros tropicais }\end{array}$ & Melhoramento & Melhoramento & $1985 / 1989$ \\
\hline $\begin{array}{l}\text { Teste clonal de E. grandis e E. urophilla para o Horto } \\
\text { Santa Fé }\end{array}$ & Melhoramento & Teste Clonal & $1985 / 1989$ \\
\hline
\end{tabular}


Tabela 19. Levantamento dos projetos do IPEF

\begin{tabular}{|c|c|c|c|}
\hline Título do projeto (vínculo temático) & Grupo & Subgrupo & $\begin{array}{c}\text { Data } \\
\text { início }\end{array}$ \\
\hline $\begin{array}{lcrr}\text { Talhão experimental de } & \text { Eucalyptus urophylla de } \\
\text { procedência } & \text { Timor } & \text { (População } & \text { Base }\end{array}$ & Melhoramento & Teste Clonal & $1985 / 1989$ \\
\hline Multiprocedências - raça local Brotas,SP) & & & \\
\hline Teste clonal de material micropropagado "in vitro" & Melhoramento & Biotecnologia & 1990/1994 \\
\hline $\begin{array}{l}\text { Configuração do sistema radicular, antes e pós } \\
\text { colheita, de um povoamento clonal do híbrido } \\
\text { Eucalyptus grandis vs. E. urophylla manejado no } \\
\text { sistema de talhadia }\end{array}$ & & & \\
\hline $\begin{array}{l}\text { Época de adubação de cobertura em povoamentos } \\
\text { clonais de eucalipto ( } 2^{\mathrm{a}} \text { rotação) }\end{array}$ & Manejo & Adubação & $1990 / 1994$ \\
\hline $\begin{array}{l}\text { Teste Clonal de E. grandis e E. urophilla para o Horto } \\
\text { Mogi Guaçu }\end{array}$ & Melhoramento & Teste Clonal & $1990 / 1994$ \\
\hline $\begin{array}{l}\text { Teste de espaçamento e clonal (propagados pos } \\
\text { estacas) para o Horto Nossa Senhora Aparecida }\end{array}$ & Melhoramento & Teste Clonal & $1990 / 1994$ \\
\hline $\begin{array}{l}\text { Teste Clonal de E. grandis e E. urophilla para o Horto } \\
\text { Mogi Guaçu }\end{array}$ & Melhoramento & Teste Clonal & $1990 / 1994$ \\
\hline Programa cooperativo de mecanização & Colheita & Mecanização & $1990 / 1994$ \\
\hline $\begin{array}{l}\text { Fenologia da frutificação de Genipa americana L. } \\
\text { (Rubiaceae) em mata ciliar do Rio Moji Guaçu, SP. }\end{array}$ & Ambiência & & \\
\hline $\begin{array}{l}\text { Teste de espaçamento e clonal de híbridos } \\
\text { micropropagados (Horto Mogi Guaçu) }\end{array}$ & Melhoramento & Teste Clonal & $1990 / 1994$ \\
\hline $\begin{array}{l}\text { Teste de espaçamento e clonal de híbridos } \\
\text { micropropagados (Horto Bela Vista) }\end{array}$ & Melhoramento & Teste Clonal & $1990 / 1994$ \\
\hline Programa cooperativo de nativas & Am & & \\
\hline Teste clonal para o Horto Gigante II & Melho & & 994 \\
\hline $\begin{array}{l}\text { Recomendações para o monitoramento hidrológico } \\
\text { na INPACEL S/A }\end{array}$ & Ambiência & Microbacias & $1990 / 1994$ \\
\hline $\begin{array}{l}\text { Características do sistema } \\
\text { povoamentos de } \\
\text { sementes e estacas }\end{array}$ & Manejo & & $1990 / 1994$ \\
\hline $\begin{array}{l}\text { Teste clonal para o solo Areia Quartzosa profunda no } \\
\text { Horto Gramado }\end{array}$ & Melhoramento & Teste Clonal & $1990 / 1994$ \\
\hline $\begin{array}{l}\text { Efeito do meio de cultura líquido e sólido no } \\
\text { crescimento e desenvolvimento de gemas de }\end{array}$ & Melhoramento & Biotecnologia & $1995 / 1999$ \\
\hline $\begin{array}{l}\text { Eucalyptus grandis x Eucalyptus urophylla na } \\
\text { multiplicação in vitro }\end{array}$ & & & \\
\hline $\begin{array}{l}\text { Variação da qualidade da madeira entre grupos } \\
\text { fenotípicos de clones de Eucalyptus urophylla S.T. } \\
\text { Blake da llha de Flores, Indonésia }\end{array}$ & Tecnologia & $\begin{array}{l}\text { Qualidade da } \\
\text { madeira }\end{array}$ & $1995 / 1999$ \\
\hline Teste clonal com mudas macropropagadas & Melhora & Test & $1995 / 1999$ \\
\hline $\begin{array}{l}\text { Programa cooperativo de monitoramento de insetos } \\
\text { e proteção florestal }\end{array}$ & Melhoramento & & $1995 / 1999$ \\
\hline $\begin{array}{l}\text { Efeito de práticas de cultivo mínimo e preparo } \\
\text { intensivo de solo }\end{array}$ & Manejo & Preparo do & $1995 / 1999$ \\
\hline $\begin{array}{l}\text { Efeito da matéria orgânica e do fósforo no } \\
\text { desenvolvimento de ectomicorrizas em "plantlets" de } \\
\text { eucalipto inoculadas "in vitro" com Pisolithus } \\
\text { tinctorius }\end{array}$ & Melhoramento & Biotecnologia & $1995 / 1999$ \\
\hline
\end{tabular}


Tabela 19. Levantamento dos projetos do IPEF

\begin{tabular}{|c|c|c|c|}
\hline Título do projeto (vínculo temático) & Grupo & Subgrupo & $\begin{array}{c}\text { Data } \\
\text { início }\end{array}$ \\
\hline $\begin{array}{l}\text { Enraizamento "ex vitro" de gemas de Eucalyptus } \\
\text { spp. multiplicadas e alongadas "in vitro" }\end{array}$ & Melhoramento & Biotecnologia & $1995 / 1999$ \\
\hline $\begin{array}{l}\text { Variação da qualidade da madeira entre grupos } \\
\text { fenotípicos de clones de Eucalyptus urophylla S.T. } \\
\text { Blake da Ilha de Flores, Indonésia }\end{array}$ & Tecnologia & $\begin{array}{l}\text { Qualidade da } \\
\text { madeira }\end{array}$ & $1995 / 1999$ \\
\hline $\begin{array}{l}\text { Variação genética de indicadores de tensão de } \\
\text { crescimento em clones de Eucalyptus urophylla }\end{array}$ & Tecnologia & & $1995 / 1999$ \\
\hline $\begin{array}{l}\text { Modelos generalizados para a mortalidade de } \\
\text { árvores de Eucalyptus grandis no estado de São } \\
\text { Paulo, Brasil }\end{array}$ & Manejo & Inventário & $1995 / 1999$ \\
\hline $\begin{array}{l}\text { Valorização da madeira do híbrido Eucalyptus } \\
\text { grandis x urophilla através da produção conjunta de } \\
\text { madeira serrada em pequenas dimensões, celulose } \\
\text { e lenha }\end{array}$ & Tecnologia & $\begin{array}{l}\text { Qualidade da } \\
\text { madeira }\end{array}$ & $1995 / 1999$ \\
\hline $\begin{array}{l}\text { Utilização de imagens de videografia aérea na } \\
\text { detecção de deficiências nutricionais em plantios de } \\
\text { eucalipto }\end{array}$ & Manejo & $\begin{array}{l}\text { Geoprocessam } \\
\text { ento }\end{array}$ & $1995 / 1999$ \\
\hline Projeto de genotipagem de clones & Melhoramento & Biotecnologia & 1995/1999 \\
\hline Projeto sobre microbacias hidrográficas & Ambiência & Microbs & $2000 / 2004$ \\
\hline Programa temático de proteção florestal & Melhoramento & Proteção & $2000 / 2004$ \\
\hline $\begin{array}{l}\text { Projeto de produtividade florestal e balanço de } \\
\text { carbono }\end{array}$ & Manejo & Produtividade & $2000 / 2004$ \\
\hline $\begin{array}{l}\text { Projeto de um sistema de drenagem para viveiro de } \\
\text { mudas e projeto de sistema de recirculação de águas } \\
\text { de irrigação e drenagem em viveiro de mudas }\end{array}$ & Melhoramento & Viveiro & $2000 / 2004$ \\
\hline $\begin{array}{l}\text { Monitoramento contínuo de parâmetros indicadores } \\
\text { da qualidade da água, da conservação do solo e } \\
\text { ciclagem de nutrientes na microbacia experimental } \\
\text { da International Paper do Brasil - Horto Bela Vista }\end{array}$ & Ambiência & Microbacias & $2000 / 2004$ \\
\hline $\begin{array}{l}\text { Projeto de avaliação dos testes de distingüibilidade, } \\
\text { homogeneidade e estabilidade }\end{array}$ & Melhoramento & Biotecnologia & $2000 / 2004$ \\
\hline $\begin{array}{l}\text { Caracterização hídrica superficial do horto ouro } \\
\text { verde }\end{array}$ & Ambiência & Microbacias & $2000 / 2004$ \\
\hline $\begin{array}{l}\text { Projeto de implementação de rede experimental de } \\
\text { parcelas gêmeas em São Paulo }\end{array}$ & Manejo & Produtividade & $2000 / 2004$ \\
\hline $\begin{array}{l}\text { Projeto sobre controle biológico do Psilideo-de- } \\
\text { concha Glycaspis brimblecombei em florestas de } \\
\text { Eucalyptus. }\end{array}$ & Melhoramento & Proteção & $2000 / 2004$ \\
\hline $\begin{array}{l}\text { Morcegos frugívoros e nectarívoros: impacto da } \\
\text { monocultura extrativista de eucalipto e o papel da } \\
\text { quiropterofauna na regeneração do Parque Florestal } \\
\text { São Marcelo }\end{array}$ & Ambiência & & $2000 / 2004$ \\
\hline $\begin{array}{l}\text { Monitoramento, manejo e uso do hábitat por } \\
\text { mamiferos em áreas alteradas e em recuperação do } \\
\text { Parque Florestal São Marcelo. }\end{array}$ & Ambiência & & $2000 / 2004$ \\
\hline
\end{tabular}


Tabela 19. Levantamento dos projetos do IPEF

\begin{tabular}{|c|c|c|c|}
\hline Título do projeto (vínculo temático) & Grupo & Subgrupo & $\begin{array}{c}\text { Data } \\
\text { início }\end{array}$ \\
\hline $\begin{array}{l}\text { Manejo de aves e mamíferos frugívoros e seu } \\
\text { impacto na recuperação das áreas alteradas no } \\
\text { Parque São Marcelo }\end{array}$ & Ambiência & & $2000 / 2004$ \\
\hline Projeto Bepp & Manejo & Produtividade & $2000 / 2004$ \\
\hline
\end{tabular}




\section{REFERÊNCIAS BIBLIOGRÁFICAS}

ALENCAR, J.R. Evaluación del cambio tecnológico en pinus una aplicación en la región sur de Brasil. Córdoba, 1999. 178p. Tese (Doutorado) Universidad de Córdoba.

ALFENAS, A.C.; ZAUZA, E.A.V. Clonagem e algumas doenças de Eucalyptus em viveiro e campo. Viçosa: Universidade Federal de Viçosa, 2002. p.12-40: Clonagem de Eucalyptus.

ANDRADE, H.B. Eficiência dos experimentos com clones na cultura do eucalipto. Lavras, 2002. 162p. Tese (Doutorado) - Universidade Federal de Lavras.

ASSIS, T.F.; GONÇALVES, A.N.; HIGASHI, E.N.; SILVEIRA, R.L.V.A. Propagação vegetativa de Eucalyptus por microestaquia. In: REUNIÃO TÉCNICA DE PROPAGAÇÃO VEGETATIVA, 9.; REUNIÃO TÉCNICA DE SILVICULTURA CLONAL,1., Piracicaba, 1996. Anais. Piracicaba: IPEF, 1996. p.9.

BARRICHELLO,L.E.G. 25 anos de Pesquisas para o Progresso do Setor $\begin{array}{lllll}\text { Florestal } & \text { Brasileiro. } & \text { IPEF, } & \text { n.46, } & \text { p.1-7, }\end{array}$ 
BENGSTON, D. N. Economic impact of structural particleboard research. Forest Science, v.30, n.3, p.685-697, 1984.

BENGSTON, D. N. Economic evaluation of agricultural research: an assessment. Evaluation Review, v.9, n.3, p.243-262, 1985.

BRIGATTI, R.A.; FERREIRA, M.; BEIG, O.; FREITAS, M. Polinização controlada de Eucalyptus uroplhylla. Um programa desenvolvido pela Champion Papel e Celulose. Silvicultura, v.8, n.28, p.213-215, 1983.

CALLAHAM, R. Z. Criteria for deciding about forestry research programs. Washington: Department of Agriculture and Forest Service, 1981. 52p.

COMERIO, J. Novas abordagens do melhoramento florestal na Champion Papel e Celulose. Mogi Guaçu: Champion Papel e Celulose, 1994. 31p. (Relatório interno).

CAMPINHOS, E.J.; IKEMORI, Y.K. Nova técnica para produção de mudas de essências florestais. IPEF, n.23, p.47-52, 1983.

CAMPINHOS, E.N.; IANELLI,C.M.; CARDOSO, N.Z.; ALMEIDA, M.A.; ROSA.A.C. Hidrojardim clonal Champion: uma otimização na produção de mudas de eucalipto. Silvicultura, n.80, p.42-46, 1999.

COLLI, G.J.; VASTANO,B.J.; MORO, L.; VIEIRA, J.D. Informações gerais de pesquisa da área florestal da Champion Papel e Celulose In: SIMPÓSIO IPEF, Piracicaba, 1989. Anais. Piracicaba: IPEF, 1989. p.59-65. 
DAVIS, J.S.; MCKENNEY, W.D. TURNBULL, J.W. The international impacts of forestry research and a comparison with agricultural and fisheries research. Canadian Journal of Forestry Research, v.24, n.2, p.321-336, 1994.

FERREIRA, M. A Experiência dos Convênios Universidade-Empresa. In: SIMPÓSIO AS PERSPECTIVAS DE PESQUISA FLORESTAL NO BRASIL, Piracicaba, 1993. Anais. Piracicaba: IPEF, 1993. p.29-51.

FISHEL,W.L. Changes in the need for reseach and extension evaluation information. In: NORTON, G.W.; FISHEL, W.L.; PAULSEN, A.A.; SUNDQUIST, W.B. (Ed.). Evaluation of agricultural research. St. Paul: University of Minnesota, Agricultural Experiment Station, 1981. p.9-17.

FISHWICK, R. Pesquisas de intensidade de desbastes. FAO/IBDF Boletim Informativo, n.1, p.40-56, 1974.

FREITAS, M. Novos conceitos no campo da implantação e manutenção. Champion Papel e Celulose. Mogi Guaçú Champion Papel e Celulose, 1985. 10p.

FREITAS, M.; SILVA, A.P.; DINIZ, A.S.; KAGEYAMA, P.Y.; FERREIRA, M. The research programme with Eucalyptus grandis Hill Ex-Maiden at Champion papel e celulose S.A. Silvicutura, v.8, n.31, p.537-539, 1983.

FREITAS, M.; SILVA, A.P.; DINIZ, A.S.; MORO, L.; VIEIRA, J.D. Novas práticas adotadas no manejo florestal. In: SIMPÓSIO IPEF, Piracicaba, 1991. Anais. Piracicaba, 1991. p.20-26. 
FREITAS, G.D.; SIQUEIRA JUNIOR, L. Avaliação do programa de pesquisas sobre meio ambiente em empresas florestais. In: SIMPÓSIO BRASILEIRO DE PESQUISA FLORESTAL, Belo Horizonte, 1993. Anais. Belo Horizonte: SIF, 1993. p.108-118.

FREITAS, M.; ANTIQUEIRA, A.C. Sistema Mecanizado de Colheita Florestal na Champion Papel e Celulose Ltda. In: CONGRESSO FLORESTAL PANAMERICANO $1^{\circ}$, Curitiba, 1993. Anais. Curitiba: Sociedade Brasileira de Silvicultura, 1993. p.686-687.

GALVÃO, A.P.M. Programa nacional de pesquisa florestal. Brasília: EMBRAPA, IBDF, PNPF, 1982. 35p.

GAVA, I. C.; VIEIRA, J.D. Manual de polinização controlada para Eucalyptus spp. Mogi Guaçú: Champion Papel e Celulose. 1988. 10p. (Relatório interno).

HAYGREEN, J.; GREGERSEN, H.; HOLLAND, I.; STONE, R. The economics impact of timber utilization research. Forest Products Journal, v.36, n.2, p.12-20, 1986.

HELLSTROM, E., PALO, M. European Forestry Research - public and private involvement. In: IUFRO, Cape Town - South Africa, 1994. Proceedings. Cape Town: International Union of Forestry Research Organization, 1994. p.365-392.

HYDE, W.F.; NEWMAN, D.H.; SELDON, B.J. The economic benefits of forestry research. New York: lowa State University Press, 1992, 241 p. 
HOSOKAWA, R.H. Evolução científica e tecnológica do manejo de florestas equiâneas. In: SIMPÓSIO BRASILEIRO DE PESQUISA FLORESTAL, Viçosa, 1999. Anais. Viçosa: SIF, 1999. p.90-102.

INSTITUTO DE PESQUISA E ESTUDOS FLORESTAIS. Relatório anual 1978. Piracicaba, 1979. 123p.

INSTITUTO DE PESQUISA E ESTUDOS FLORESTAIS. Relatório anual 1980. Piracicaba, 1981. 85p.

INSTITUTO DE PESQUISA E ESTUDOS FLORESTAIS. Relatório anual 1981. Piracicaba, 1982. 69p.

INSTITUTO DE PESQUISA E ESTUDOS FLORESTAIS. Relatório anual 1983. Piracicaba, 1984. 20p.

INSTITUTO DE PESQUISA E ESTUDOS FLORESTAIS. Relatório anual 1984. Piracicaba, 1985. 132p.

INSTITUTO DE PESQUISA E ESTUDOS FLORESTAIS. Relatório anual 2001. Piracicaba, 2002. 85p.

JAKES, P.J.; RISBRUDT, C.D. Evaluating the impacts of forestry research: rates of return for forestry research are comparable to those for agricultural research. Journal of Forestry Research, v.86, n.3, p.36-39, 1988.

LADEIRA, H. P. Quatro décadas de engenharia florestal no Brasil. Viçosa: Sociedade de Investigações Florestais, 2002. p.55-75. 
LEÃO, R.M. A floresta e o homem. São Paulo: EDUSP; Piracicaba: IPEF, 2000. 434p.

MCKENNEY, D. W.; DAVIS, J. S.; TURNBULL, J.W.; SEARLE, S.D. Impact of Australian tree species selection research in China: an economic perspective. Forest Ecology and Management, v.60, n.1/2, p.59-76, 1993.

MCKENNEY, D.W.; BEKE, N.; FOX, G.; GROOT, A. Does it pay to do silviculture research on a slow growing species? Forest Ecology and Management, v.95, n.2, p.141-152, 1997.

MORA, A.L.; FERREIRA, M. Estudo de florescimento de Eucalyptus urophylla. IPEF Boletim Informativo, p.23-29, 1980.

NORTON, G. W.; DAVIS, J. S. Evaluating returns to agriculture research: a Review, American Journal of Agricultural Economics, v.63, n.4, p.689689, 1981.

PETERSON, W.L. The returns to investment in agricultural research in the United State. St. Paul: University of Minnenosta Departament of Agricultural and Applied Economics, 1969. 38p. (Staff Paper 69-5).

PORTO, G.S. A decisão empresarial de desenvolvimento tecnológico por meio da cooperação empresa-universidade. São Paulo, 2000. 276p. Tese (Doutorado) - Faculdade de Economia, Administração e Contabilidade da Universidade de São Paulo. 
REZENDE, J.L.P. Evolução da ciência e da pesquisa florestal no Brasil. In: SIMPÓSIO BRASILEIRO DE PESQUISA FLORESTAL, Belo Horizonte, 1993. Anais. Belo Horizonte: SIF, 1993. p.44-71.

REZENDE, J.L.P.; OLIVEIRA, A.D. Análise econômica de projetos florestais. Viçosa: Universidade Federal de Viçosa, 2001. p.182-193.

RODRIGUEZ, L.C.E.; SEIXAS, F.; SILVA - JUNIOR, F.G.; GONÇALVES, J.L.M.; STAPE, J.L.; LIMA, J.O.B.P.; AMARAL, W.A.N.; FREITAS, A.R.H.R. Ciência e tecnologia no setor florestal brasileiro: diagnóstico, prioridades e modelos de financiamento. Brasília: Ministério da Ciência e Tecnologia, 2002. 134p. (Relatório Final).

ROSENBERG, N.; NELSON, R.R. American Universities and Technical Advance in Industry. Research Policy, v.23, n.3, p.323-348, 1994.

RUSSEL, D.G. Resource allocation in agricultural research using socialeconomic evaluation and mathematical models. Canadian Journal of Agriculture Economics, v.23, n.1, p.29-52, 1975.

SEGATTO-MENDES, A.P. Teoria de agência aplicada à análise de relação entre os participantes dos processos de cooperação tecnológica Universidade-Empresa. São Paulo, 2001. 260p. Tese (Doutorado) Faculdade de Economia, Administração e Contabilidade da Universidade de São Paulo.

SELDON, B.J. Marginal productivity of public research in the softwood plywood industry. Forest Science, v.33, n.4, p.872-888, 1987. 
SORESINI L. Benefícios sociais e econômicos da pesquisa florestal. In: SIMPÓSIO BRASILEIRO DE PESQUISA FLORESTAL, Belo Horizonte, 1993. Anais. Belo Horizonte: SIF, 1993. p.300-305.

SOUZA, A.P.; MACHADO, C.C.; MINETTI, L.J.; JACOVINE, L.A.G. Pesquisa na área de colheita e transporte florestal. In: SIMPÓSIO BRASILEIRO DE PESQUISA FLORESTAIS, Viçosa. Anais. Viçosa: SIF; UFV, 1999. p.4389.

VIEIRA, J.D.; BRESSAM, C.; DINIZ, A.S.; FREITAS, M. Clonal silviculture et Champion Papel e Celulose Ltda. In: SYMPOSIUM ON MASS PRODUCTION TECHNOLOGY FOR GENETICALLY IMPROVED FAST GROWING FOREST TREE SPECIES, Bordeaux, 1992. Proceedings. Bordeaux: AFOCEL,1992. v.1, p.283-291.

WENDLING, I.; XAVIER, A.; GOMES, J.M.; PIRES, I.E.; ANDRADE, H.B. Efeito do regulador de crescimento AIB na propagação de clones de Eucalyptus spp. por miniestaquia. Revista Árvore, v.24, n.2, p.187-192, 2000.

XAVIER, A.; COMÉRIO, J. Microestaquia: uma maximização da micropropagação de Eucalyptus. Revista Árvore, v.20, n.1, p.9-16, 1996.

XAVIER, A.; COMÉRIO, J.; IANNELLI, C.M. Eficiência da estaquia, da microestaquia e da micropropagação na clonagem de Eucalyptus spp. In: CONFERÊNCIA IUFRO SOBRE SILVICULTURA E MELHORAMENTO DE EUCALYPTUS, Salvador, 1997. Proceendings. Colombo: EMBRAPA, Centro Nacional de Pesquisas de Florestas, 1997. v.2, p.40-45. 